UNIVERSIDADE DE SÃO PAULO

FACULDADE DE ECONOMIA, ADMINISTRAÇÃO E CONTABILIDADE DEPARTAMENTO DE ADMINISTRAÇÃO PROGRAMA DE PÓS-GRADUAÇÃO EM ADMINISTRAÇÃo

IMPACTO DA INTEROPERABILIDADE NA EFICIÊNCIA DE PROCESSOS INTERGOVERNAMENTAIS DE GOVERNO ELETRÔNICO: O CASO DA MATRÍCULA ESCOLAR NO ESTADO DE SÃO PAULO

Antonio Celso de Paula Albuquerque Filho

Orientador: Prof. Dr. Cesar Alexandre de Souza 
Prof. Dr. João Grandino Rosas

Reitor da Universidade de São Paulo

Prof. Dr. Reinaldo Guerreiro

Diretor da Faculdade de Economia, Administração e Contabilidade

Prof. Dr. Adalberto Américo Fischmann

Chefe do Departamento de Administração

Prof. Dr. Lindolfo Galvão de Albuquerque

Coordenador do Programa de Pós-Graduação em Administração 


\section{IMPACTO DA INTEROPERABILIDADE NA EFICIÊNCIA DE PROCESSOS INTERGOVERNAMENTAIS DE GOVERNO ELETRÔNICO: O CASO DA MATRÍCULA ESCOLAR NO ESTADO DE SÃO PAULO}

Dissertação apresentada ao Departamento de Administração da Faculdade de Economia, Administração e Contabilidade da Universidade de São Paulo como requisito para obtenção do título de Mestre em Administração.

Orientador: Prof. Dr. Cesar Alexandre de Souza

\section{Versão Corrigida}

(versão original disponível na Faculdade de Economia, Administração e Contabilidade)

\section{SÃO PAULO}




\section{FICHA CATALOGRÁFICA}

\section{Elaborada pela Seção de Processamento Técnico do SBD/FEA/USP}

Albuquerque Filho, Antonio Celso de Paula

Impacto da interoperabilidade na eficiência de processos intergovernamentais de governo eletrônico: o caso da matrícula escolar no Estado de São Paulo / Antonio Celso de Paula Albuquerque Filho. -- São Paulo, 2012. $262 \mathrm{p}$.

Dissertação (Mestrado) - Universidade de São Paulo, 2012.

Orientador: Cesar Alexandre de Souza.

1. Sistemas de governo 2. Interoperabilidade 3. Governo estadual 4. Governo municipal 5. Matrícula escolar I. Universidade de São Paulo. Faculdade de Economia, Administração e Contabilidade. II. Título.

CDD - 321 

A meus filhos, razão da minha felicidade. 

Agradeço ao professor e orientador Cesar Alexandre de Souza, sempre compreensivo e disposto a me conduzir com retidão. Sua paciência e sabedoria garantiram bom termo a este trabalho.

Agradeço a Lícia Mutsuko Abe, que mais de uma vez me ajudou a cumprir os prazos e toda a burocracia da universidade, mesmo não havendo nenhuma obrigação em fazê-lo. Agradeço aos entrevistados, Alexandre Mendes, Alexandre Schnieder, Felipe Soutello, Fernando Padula, Harry Walter Finger Roberts, Luiz Augusto Moraes, Marcos Tadeu Yazaki, Maria de Fátima Borges de Oliveira, Maria Nicia Pestana de Castro, Norberto Torres, Rubens Naman Rizek, Valmir Aquilino de Freitas e Whalter Araujo de Aquino, que doaram seu tempo para me auxiliar.

Agradeço à família Líbera, que em diversos momentos me auxiliou na revisão e me incentivou no desenvolvimento de artigos e trabalhos, em especial à Camila, que sempre esteve presente me incentivando.

Agradeço à minha mãe que foi além, movimentando recursos como o talentoso Aimã, a quem agradeço por me auxiliar nas transcrições das entrevistas.

Agradeço à Dra. Evelyn, minha terapeuta, sem seu auxílio não teria o equilíbrio necessário para suportar todas as mudanças que passei nos últimos dois anos e meio. Agradeço a Deus que me deu fé e força para superar os momentos de angústia.

Por fim agradeço a todos os mestres, colegas e amigos que disponibilizaram tempo e recursos para me auxiliar na obtenção dos créditos e no desenvolvimento da dissertação. A solidariedade que recebi está eternizada no meu coração. 
“Porventura agradecerá ao servo porque este fez o que lhe foi mandado?"

Lucas 17,9 



\section{RESUMO}

Neste trabalho é avaliado o impacto da interoperabilidade intergovernamental na melhoria da eficiência nos processos de governo eletrônico, em especial entre estados e municípios. Governo Eletrônico é visto como o uso intensivo de tecnologia da informação para atender às necessidades do Estado com foco nos cidadãos, visando otimizar os processos governamentais. A Interoperabilidade é a capacidade de troca transparente de dados entre sistemas. A união dos dois conceitos, aplicada nas relações intergovernamentais, tem como objetivo propiciar, principalmente ao poder executivo nas três instâncias - união, estados e municípios -, a troca de dados de forma transparente e desburocratizada, buscando a melhoria do atendimento ao cidadão e da eficiência, eficácia e efetividade entre os entes federados.

Para compreender a influência da interoperabilidade na eficiência destes processos foi analisado o processo de matrículas escolares entre os sistemas do estado e do município de São Paulo. No Estado de São Paulo são realizadas, anualmente, cerca de dez milhões de matrículas no ensino básico, sendo um terço (três milhões e meio aproximadamente) no município de São Paulo. Partindo-se da descrição histórica do processo de implantação, são apresentadas as motivações que levaram à criação de interoperabilidade entre os sistemas de matrícula dos dois entes federados, barreiras encontradas para a implantação, como foram enfrentadas e o impacto na eficiência tanto nos processos internos quanto no atendimento à população. Além de o processo ter sido simplificado com a interoperabilidade, conclui-se que o impacto na eficiência dos processos internos de controle e gestão dos sistemas foi grande, principalmente nas secretarias de escolas, onde foram percebidas melhorias significativas, apesar de persistirem outros problemas no processo como um todo. 




\begin{abstract}
In this paper, the impact of intergovernmental interoperability in improving e-government processes efficiency between states and municipalities is evaluated.

E-Government is the intensive use of information technology to meet the state's needs with a focus on citizens in order to optimize governmental processes. Interoperability is the ability of transparent data exchange between systems. The joint of the two concepts, applied to intergovernmental relations, aims to provide, mainly to the executive in three instances union, states and municipalities-, to exchange data seamlessly, without bureaucracy, seeking to improve public service and the state's efficiency, efficacy and effectiveness.

In order to understand interoperability's influence in the efficiency of these processes we have analyzed school enrollment's process among São Paulo city and state's systems.

In São Paulo state annually about ten million enrollments in primary education are performed, being a third part (three and a half million approximately) in São Paulo city. Based on the historical description of the deployment process, in this paper are presented the motivations that led to the creation of interoperability between registration's systems of the two federal entities, the barriers encountered to the deployment and how they were faced, and the impact on efficiency in both internal processes and in the service to population. We also conclude that the impact on efficiency of internal control processes and management systems was of great deal, as well as in the schools secretariats, where significant improvements in efficiency were perceived, although other problems persist in the process as a whole.
\end{abstract}






\section{SUMÁRIO}

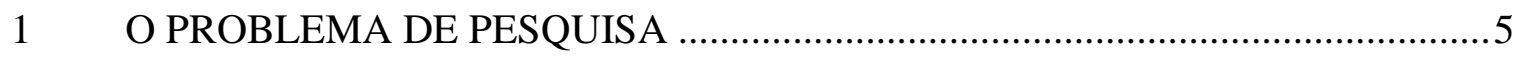

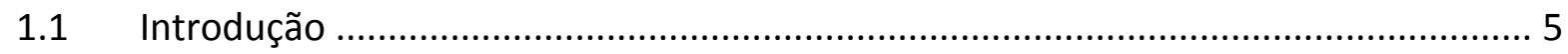

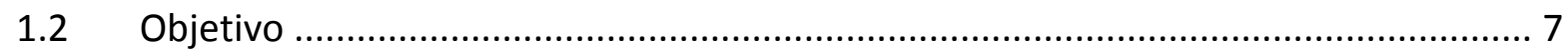

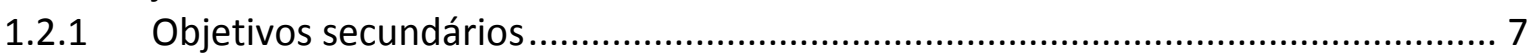

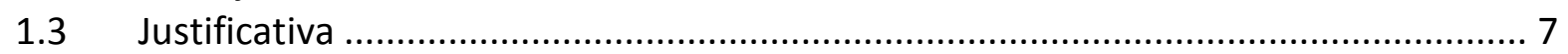

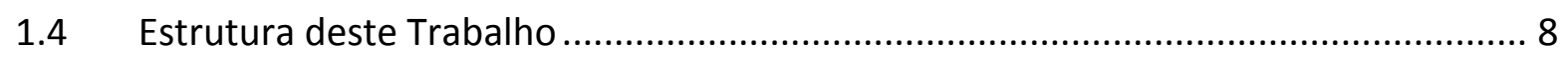

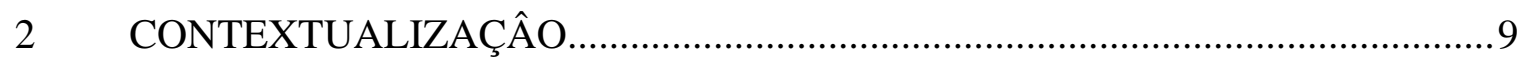

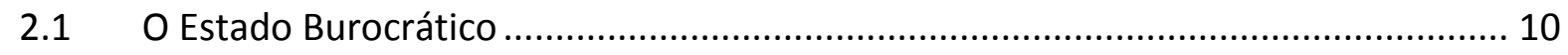

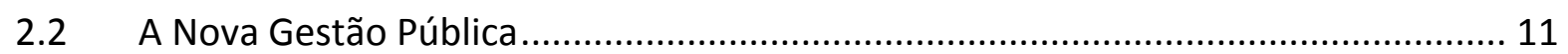

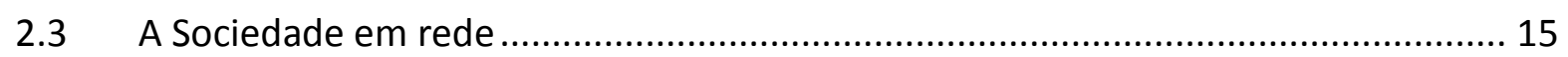

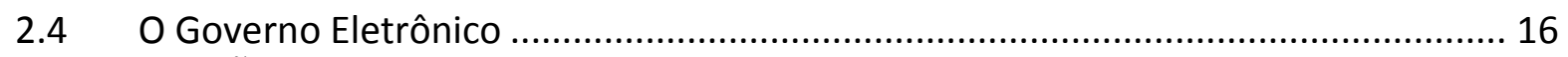

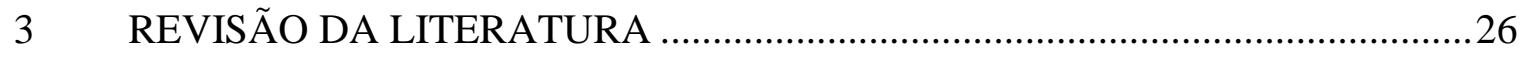

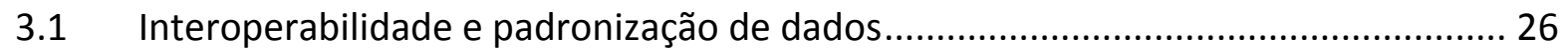

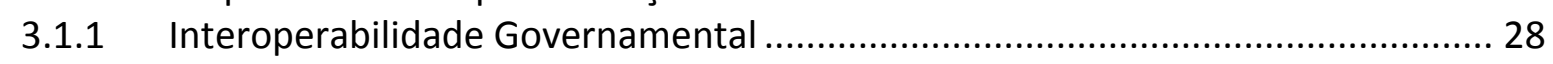

3.1.2 Padrões estruturados para a interoperabilidade de sistemas........................... 30

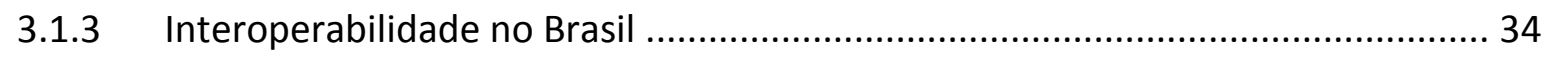

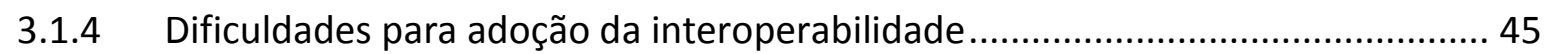

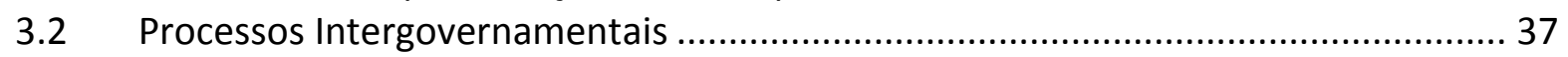

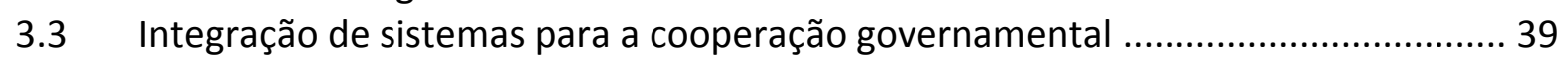

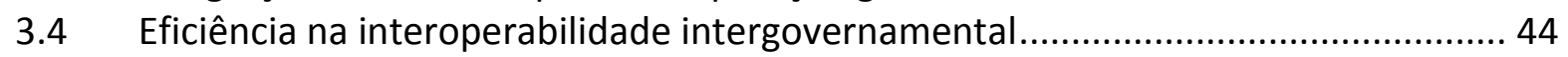

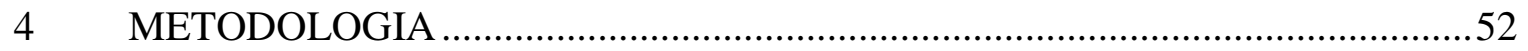

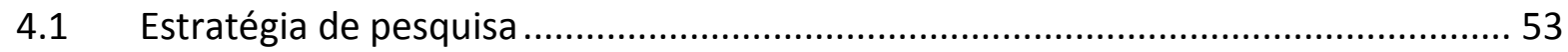

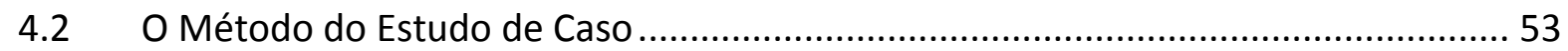

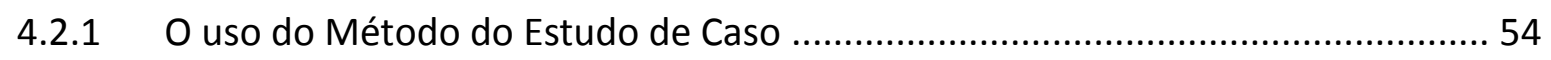

4.3 O projeto de pesquisa com o método do Estudo de Caso ....................................... 55

4.3.1 Delimitações da pesquisa - questões a serem estudadas .................................. 56

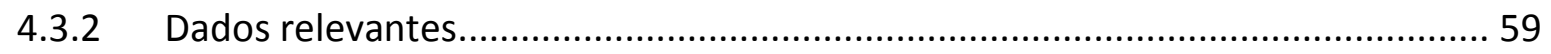

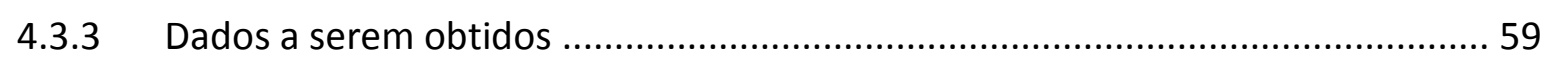

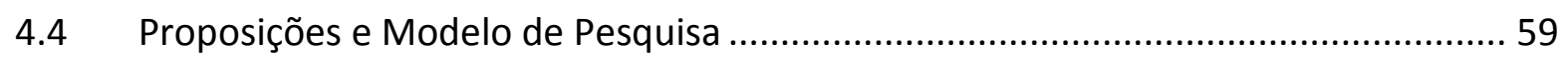

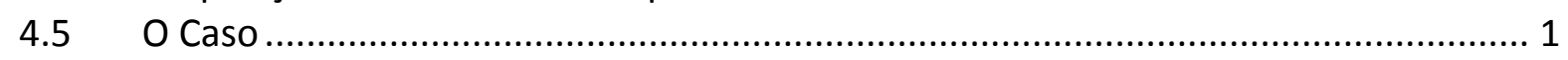

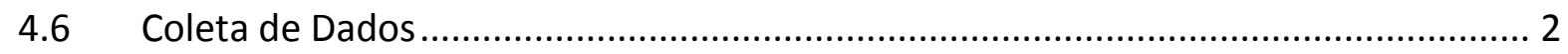

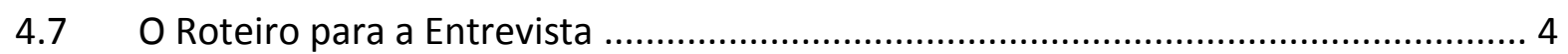

4.8 Ligação entre os Dados e as Proposições .................................................................. 7

4.9 Apresentação e Análise do Caso.................................................................................. 8

4.10 Critérios para Interpretar os Resultados e Limitações da Pesquisa ............................ 9

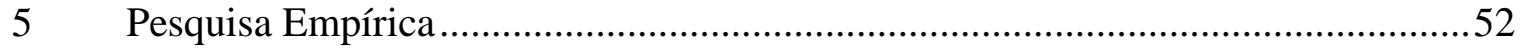

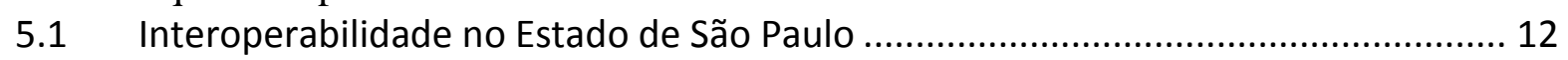

5.2 O caso das Matrículas Escolares no Estado de São Paulo .......................................... 17

5.2.1 O processo de matrícula no Estado de São Paulo ................................................. 17

5.2.2 A origem da interoperabilidade como solução para o processo de matrículas

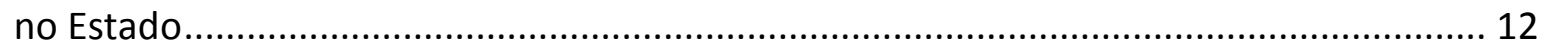

5.2.3 Interoperabilidade na educação: uma união de fatores .................................. 24

5.2.4 A influência da opinião pública .................................................................... 26

5.2.5 O problema das matrículas no município de São Paulo ................................... 27 


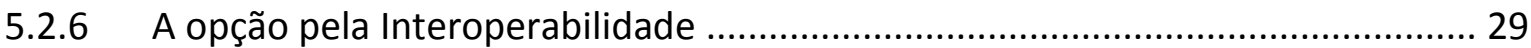

5.2.7 O Sistema de Matrículas do Estado de São Paulo - JCA ....................................... 31

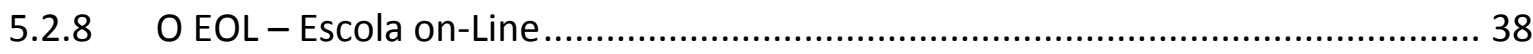

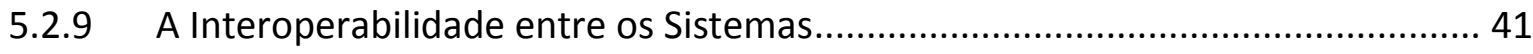

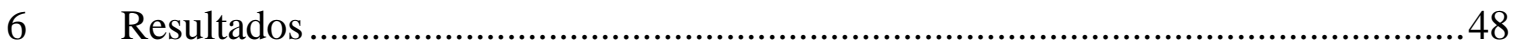

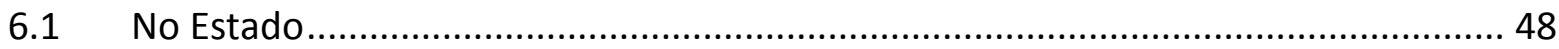

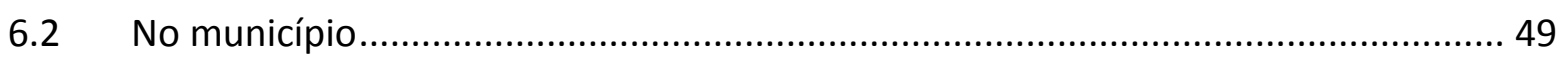

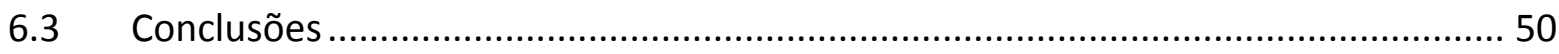

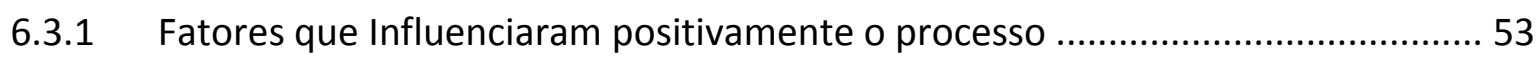

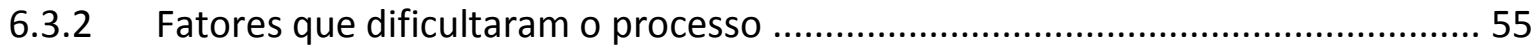

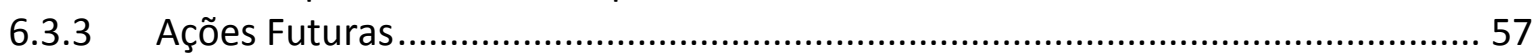

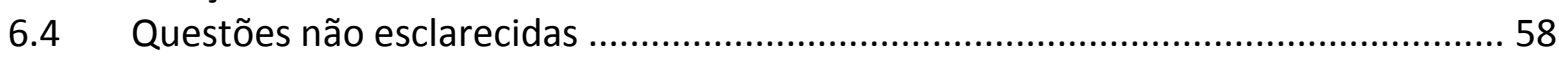

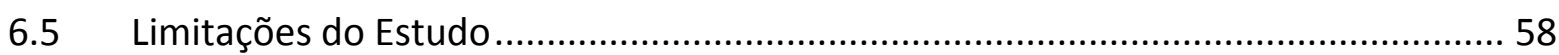

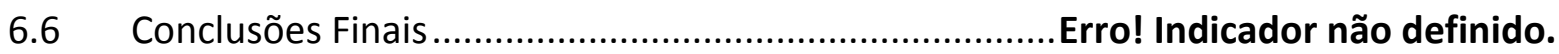

REFERÊNCIAS .............................................................. Erro! Indicador não definido. 


\section{LISTA DE TABELAS}

Tabela 6: E-government Readiness Index .22

Tabela 1: Definições da União Europeia sobre interoperabilidade............................. 31

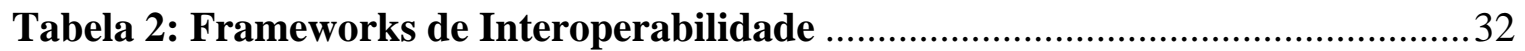

Tabela 3 Aspectos da interoperabilidade atendidos em 6 países...............................33

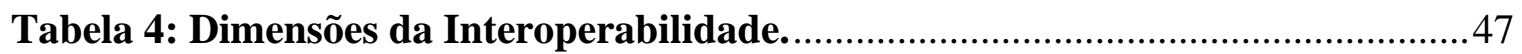

Tabela 5: resultados da pesquisa no Estado de São Paulo ...................................... 49

Tabela 7: Evolução da taxa de frequência líquida a estabelecimento de ensino das

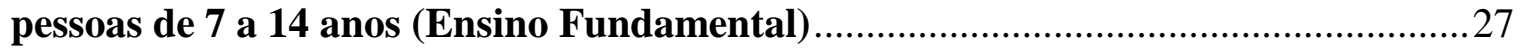

Tabela 8: Matrículas de 2008 a 2010 da Rede Municipal de Ensino no Município de

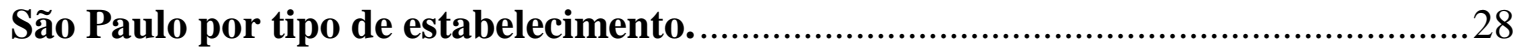

Tabela 9: Dimensões da Interoperabilidade de Pardo e Burke aplicadas ao caso.....52 


\section{LISTA DE ILUSTRAÇÕES}

Figura 1: A camada de integração.

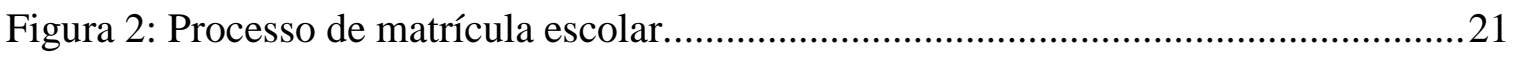

Figura 3: Esquema de comunicação entre EOL e JCA................................................... 31

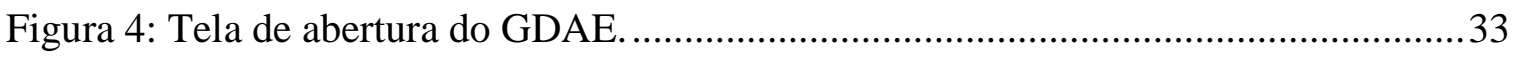

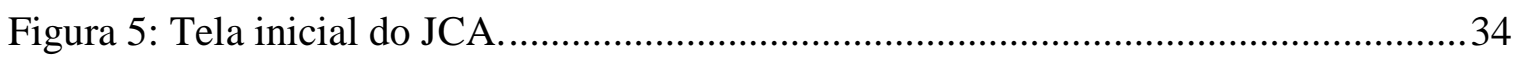

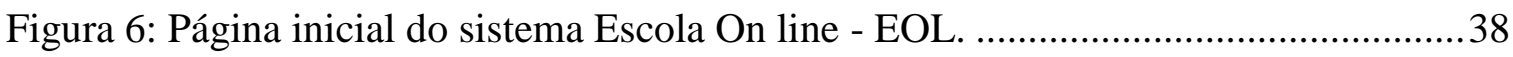

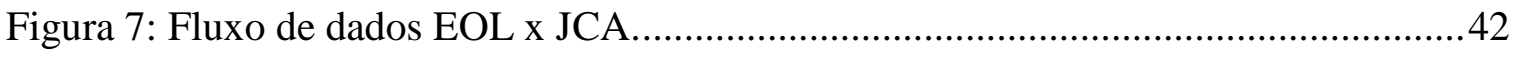

Figura 8: Processos de envio e reenvio de informações entre EOL e JCA.........................45

Figura 9: Processo de liberação de registros pendentes na interoperabilidade entre EOL e JCA. .46 


\section{O PROBLEMA DE PESQUISA}

\subsection{Introdução}

A separação das ações do governo por especialidades (Saúde, Educação, Turismo, etc.) segue uma linha clássica da administração, em que se gerencia por departamentalização. Este modelo sempre foi eficiente, permitindo um foco mais acurado nos problemas de cada área, tendo sido adotado no Brasil desde o início da república.

A informatização do Estado aconteceu de forma análoga, gerando sistemas independentes, verticalizados, não havendo preocupação com as possíveis interações entre as áreas de governo. Os sistemas foram desenvolvidos desacoplados, seja para a execução das atividades-fim de cada secretaria, seja para a execução de atividades meio, como gestão documental, compras, execução orçamentária, controle de patrimônio, etc.

No entanto, com as mudanças socioeconômicas que vêm transformando o mundo desde meados do século passado, identificadas por Manuel Castells (2010), entre outros, já não é mais aceitável o isolamento de informações, o trabalho estanque, centrado apenas no próprio enfoque, característico das organizações públicas tradicionais. Há a necessidade de inserção do Governo no contexto da Sociedade em Rede.

Na mesma direção, a Nova Gestão Pública (NGP), que surgiu e adquiriu força no final do século passado, preconizando uma maior capacidade de decisão gerencial na ponta de atuação, gerou a necessidade de informações consistentes e em tempo real, imprescindíveis para obter mais efetividade e eficiência na ação dos gestores, permitindo uma estrutura burocratizada com enfoque na produtividade (DIAS, 2008). Um instrumento da NGP, na informatização dos sistemas governamentais, é o que foi denominado de Governo Eletrônico, "um conjunto de estratégias utilizadas pelo governo, para uso dos recursos das Tecnologias da Informação e Comunicação, com o intuito de modernizar a máquina administrativa e atender às necessidades do cidadão" (SILVA, TAVARES, et al., 2009, p. 4).

Porém, o governo eletrônico, na perspectiva da NGP, necessitava de integração para garantir a troca de informações entre sistemas governamentais, de maneira a gerar consistência nas informações. Isso ocorreu nos sistemas financeiros por meio de troca de 
dados por arquivos, mas nas áreas sociais não existia a garantia da integridade e atualidade da informação. Em contraposição, na iniciativa privada a integração de sistemas se ampliava junto às telecomunicações, tornando a troca de informações entre compradores e fornecedores uma prática relativamente comum (usando técnicas como o EDI - Electronic Data Interchange, que se originou nos fins da década de 60).

Neste contexto, a articulação intergovernamental e a construção de mecanismos constitucionais de coordenação, que incluam estados e municípios, para a execução de políticas públicas é um dos grandes desafios que se impõe à agenda governamental atual (COSTA, 2010). Um dos aspectos dessa agenda é a troca de informações, sendo que a geração de interoperabilidade entre os sistemas intergovernamentais já estabelecidos é uma possível forma de diminuir as barreiras institucionais. Em diversas situações essa comunicação é desejável, podendo ser citados a saúde, educação e segurança. A Saúde possui o SUS, um sistema descentralizado para o gerenciamento da Saúde criado com a constituição de 1988 (MINISTÉRIO DA SAÚDE, 2000), mas a informação já existia,composta por bases desagregadas e não integradas com estados e municípios, dificultando a troca de dados (BRANCO, 1996).

Na educação, como na saúde, o número de atendidos em um município é proporcional à transferência de recursos federais, ou seja, mais matrículas, mais recursos. Assim, tornase essencial a informação correta, pois a prefeitura pode não receber os recursos necessários aos quais tem direito. Há também a possibilidade de fraude nos números, cabendo ao Estado garantir que não existam crianças com matrícula repetida no sistema. Municípios e Estados devem fornecer informações para o INEP, órgão do governo federal, que elabora o censo escolar e gera estatísticas com base em indicadores globais, objetivando avaliar a evolução do ensino no país (BRASIL, 2007). Tanto União, estados e municípios possuem sistemas próprios para gerenciar os dados relativos à educação, porém cada instância foca em necessidades diferentes, de acordo com a atividade exercida por cada ente federado. A informatização existe desde 1996, com a implantação do SIED (NETO, 1999). Em 2007 houve um esforço de melhoria da coleta de informações para o governo federal com a implantação do EducaCenso (ENAP, 2011), porém mantendo a inserção manual ou troca de arquivos para atualização dos dados, o que sempre gerou disparidades entre os sistemas intergovernamentais. Tais situações apenas reforçam a necessidade de pensar a interoperabilidade entre os sistemas intergovernamentais. 


\subsection{Objetivo}

Pretende-se com esta dissertação responder à seguinte questão de pesquisa:

Como se desenvolve e qual o impacto da interoperabilidade na geração da eficiência em processos intergovernamentais de governo eletrônico?

\subsubsection{Objetivos secundários}

Como complemento ao objetivo principal, pretende-se:

1) Relatar como ocorre o processo de implantação da interoperabilidade entre sistemas de entes federados diferentes;

2) Identificar dificuldades e situações favoráveis para a implantação, conforme documentado na literatura, bem como novas situações vistas na prática;

3) Verificar os pontos do processo que ficaram mais ou menos eficientes.

\subsection{Justificativa}

São várias as questões que surgem quando se estuda uma habilidade em evolução. Justamente por isso, tal estudo, ainda que seja um desafio, é de extrema relevância.

Pretende-se, a partir de um foco concreto, determinar se houve melhorias na gestão que minimizaram o tempo do processo ou diminuição de custos com a interoperabilidade entre os sistemas governamentais.

A interoperabilidade é uma forma de integração baseada em padrões, muito difundida no meio industrial, no qual há diversos estudos enfocando prioritariamente questões de engenharia. Seu estudo ainda apresenta diversas oportunidades de análise em administração pública, pois se apresenta de inúmeras formas no campo dos sistemas de informação, integrando sistemas diversos (econômicos, financeiros, orçamentários, contábeis, de saúde, educação, segurança, previdência, etc.) e impactando nos processos administrativos e de comunicação das modernas organizações governamentais. 
Tal questão tem sua relevância na importância dos processos intergovernamentais dentro do modelo federativo brasileiro (onde municípios, Estados e União são todos entes federativos), levando à compreensão do que ocorre quando da adoção da interoperabilidade entre sistemas que não são desenvolvidos ou mantidos dentro da mesma esfera de poder, ou seja, quando cada sistema pode se desenvolver de forma independente. As ações de governo eletrônico são influenciadas pela interoperabilidade, cabendo um estudo sobre este impacto quando se fala em sistemas de processos intergovernamentais. O modelo federativo nacional preconiza a independência entre os poderes e níveis de governo, sendo que união, estados e municípios são considerados entes federativos igualmente representativos, existindo funções bem definidas para cada um executar; entretanto, sob a ótica de políticas públicas, tais entes geram transversalidade nas ações, havendo assim responsabilidades distintas, sem que deixe de haver, contudo, atuação conjunta e até mesmo superposição de ações. Este trabalho pretende diminuir parte da lacuna sobre o conhecimento da interoperabilidade na área pública no Brasil, bem como gerar material que possa auxiliar e servir de inspiração para novos estudos e ações práticas.

\subsection{Estrutura deste Trabalho}

Para a realização do estudo proposto o trabalho foi dividido em seis capítulos principais:

1) O presente capítulo inicial, onde é apresentado o problema de pesquisa;

2) Contextualização, onde se busca a compreensão das influências políticas e sociais que interferem nos processos intergovernamentais de governo eletrônico;

3) Revisão Bibliográfica, onde são apresentados e detalhados os conceitos de interoperabilidade, governo eletrônico e processos intergovernamentais e analisadas as eficiências que podem ser geradas pela combinação destes;

4) Metodologia, onde é explicada e justificada a metodologia adotada;

5) Pesquisa empírica, onde há o relato da pesquisa realizada;

6) Resultados: da pesquisa empírica, conclusões, limitações do estudo e propostas para novas pesquisas que podem decorrer do trabalho realizado.

Ao final são apresentadas as referências bibliográficas utilizadas. 


\section{CONTEXTUALIZAÇÂO}

Apesar de recentes na história da civilização humana, as tecnologias da informação e comunicação vêm impactando sobremaneira nossa sociedade, bem como são influenciadas pelas mudanças sociais decorrentes, que originam novas formas de utilizar e pensar as tecnologias da informação. A relevância da interoperabilidade entre sistemas de informação se insere neste processo de mudanças sociais e tecnológicas.

Nas últimas décadas, o mundo vem passando por fortes transformações associadas ao rápido desenvolvimento das tecnologias de informação e comunicação, comumente nominadas por seu acrônimo, TIC. Manuel Castells (2010) visualizou que a comunicação e os relacionamentos globalizados, permitidos pelas Tecnologias da Informação e Comunicação, criaram uma nova forma de interação social, dentro do conceito de Virtual desenvolvido por Pierre Lévy (1999), na qual relações econômicas globalizadas, o trabalho flexível e volátil, o egocentrismo, a individualização e o distanciamento das relações diretas, reais, originaram um novo modelo social: a Sociedade em Rede (CASTELLS, 2010).

A principal mudança visível é a revolução gerada pelas telecomunicações globais e a troca de informações possibilitada pelas tecnologias da informação, a partir da década de 80 do século passado, que começaram a interligar as empresas, e posteriormente as pessoas, em redes sociais virtuais, de forma a viabilizar a comunicação com qualquer habitante do planeta após seis interações, como previa a teoria criada pelo psicólogo social Stanley Milgram em 1967 (LESKOVEC e HORVITZ, 2008). Uma versão moderna da pesquisa de Milgram, utilizando o Facebook, está sendo conduzida por um grupo de estudos da Yahoo! Research, mudando a forma de encarar as relações humanas (BLAIR, 2011).

No âmbito governamental, tais mudanças originaram iniciativas como o Governo Eletrônico, que inseria o poder público nessa nova ordem social, e a Inclusão digital (ou combate à exclusão digital, brecha digital ou digital divide), que possibilitou às camadas menos favorecidas da sociedade pertencerem à rede.

Independente da tecnologia, há anos os governos vêm se estruturando no modelo burocrático (WEBER, 2002) baseado na eficiência e meritocracia, buscando garantir 
melhores serviços à população, sendo o cerne da moderna administração pública. Porém, o excesso de burocracia, e a ineficiência consequente deste excesso, detectada por Merton (1942), acabou engessando muitas atividades governamentais, sendo que a busca por maior eficiência levou à construção do que se passou a chamar de Nova Administração Pública (DIAS, 2008). Esse modelo de gestão associado ao uso intensivo de tecnologia é a origem do já citado Governo Eletrônico, termo criado pelo ex-vice-presidente americano Al Gore (FOUNTAIN, 2007).

Com a evolução do Governo Eletrônico e a necessidade dos processos permearem diferentes entes federativos (União, estados e municípios) de forma cooperada (com base nas obrigações definidas na constituição de 1988), em especial nas áreas sociais e financeiras, foi criada uma situação de retrabalho entre os sistemas governamentais, desenvolvidos por cada ente federativo para atender necessidades próprias, independente dos outros entes. Assim, gerou-se uma situação de ineficiência, pois as trocas de informação não eram realizadas de forma integrada. A interoperabilidade surge, neste contexto, como uma possível solução para esta questão de ineficiência.

\subsection{O Estado Burocrático}

O termo burocracia, derivado de bureaucratie, surgiu na França no século XVIII para designar a estrutura governamental, o exercício do poder por funcionários de escritórios, associando as repartições públicas ao apego a regras e à ineficiência derivada desta situação. É palavra composta pelo francês bureau (escritório) e pelo grego krátos (poder ou regra).

No Século XIX Weber (2002), ao analisar as formas de poder vigente, descreveu a burocracia como uma forma legítima de exercício de poder presente no Estado e nas empresas privadas, baseado em três elementos: (1) atividades distribuídas de forma fixa, como deveres oficiais; (2) a autoridade para ordenar a execução dos deveres oficiais é estável, sendo delimitada por normas bem estabelecidas; (3) tomam-se medidas metódicas para a realização regular e contínua dos deveres, sendo que a execução é por pessoas devidamente qualificadas por um regulamento específico. Weber deu novo sentido à burocracia como forma de estruturação do Estado, baseando-a em legitimidade e autoridade. A Europa vivia em plena era industrial e foi natural que o mecanicismo e o 
racionalismo dominassem sua teoria. Se, quando do desenvolvimento de sua teoria, a estrutura de governo burocrática não constituía norma histórica, a partir de Weber surge um novo profissional, o burocrata, e a burocracia foi reconhecida como uma função de Estado e da organização de empresas, substituindo a administração patrimonialista, na qual o patrimônio público era confundido com o privado (BRESSER PEREIRA, 1996).

Cinquenta anos depois, já na primeira metade do século XX, Merton (1942) questionou a racionalidade da burocracia weberiana, que considerava utópica, com um formalismo exacerbado, geradora de resistências a mudanças. No entanto, a era industrial, a democracia e o capitalismo consagraram a burocracia como elemento essencial da administração, tanto nas empresas quanto nos governos. Na segunda metade do século $\mathrm{XX}$, a burocracia tinha papel dominante na sociedade e nos governos, impactando também o mundo empresarial globalizado e transnacional. Nesse contexto, Bresser ressaltava:

\footnotetext{
A administração pública burocrática clássica foi adotada porque era uma alternativa muito superior à administração patrimonialista do Estado. Entretanto o pressuposto de eficiência em que se baseava não se revelou real. ... verificou-se que não garantia nem rapidez, nem boa qualidade nem custo baixo para os serviços prestados ao público. $\mathrm{Na}$ verdade, a administração burocrática é lenta, cara, autorreferida, pouco ou nada orientada para o atendimento das demandas dos cidadãos. (BRESSER PEREIRA, 1996)
}

\subsection{A Nova Gestão Pública}

Na década de 80 o Brasil passava por forte crise econômica, o que acelerou a informatização do trabalho. Com o uso intenso de tecnologia da informação, muitas rotinas que antes eram executadas mecanicamente passaram a ser transferidas para centros de computação. Conforme Herédia (2004), as máquinas que tiraram os homens da produção no século XVIII agora atingiam o setor de serviços, eliminando os trabalhos repetitivos da sociedade mecanicista.

Gradativamente, a comunicação mundial, que originou a globalização, se transmutou em conectividade global. Do final da década de 70 até o começo dos anos 90 a indústria passou a trocar informações em tempo real. Não havia internet, mas metodologias como o EDI (Eletronic Data Interchange) permitiam a troca de dados entre diferentes empresas, 
fazendo com que fornecedores e produtores se conectassem, dando novo sentido à teoria do Just in Time.

Segundo Prates e Galão (2007), "um dos principais fatores para obtenção de êxito no uso do EDI apontados pelas empresas foi a flexibilidade do software, pois possibilitava à empresa negociar com inúmeros parceiros que utilizam padrões diferentes”.

$\mathrm{Na}$ administração pública, especificamente no Brasil, a burocracia demonstrou-se ineficiente como solução frente ao patrimonialismo e enfrentou forte pressão popular. Segundo Bresser Pereira (1996) a crise começou no regime militar, através do uso das empresas estatais para contratar administradores para a alta gestão, em detrimento da realização de concursos públicos, impedindo a formação de uma burocracia civil forte, nos moldes propostos pela constituição de 1936. Ainda segundo Bresser:

A crise agravou-se, entretanto, a partir da Constituição de 1988, quando se salta para o extremo oposto e a administração pública brasileira passa a sofrer do mal oposto: o enrijecimento burocrático extremo. As consequências da sobrevivência do patrimonialismo e do enrijecimento burocrático, muitas vezes perversamente misturados, serão o alto custo e a baixa qualidade da administração pública brasileira. (BRESSER PEREIRA, 1996)

Como reação à situação exposta, não apenas no Brasil, mas em vários países, começaram a surgir ações para melhorar a eficiência do Estado. Esse movimento deu origem ao que foi convencionado chamar de Nova Gestão Pública - NGP (DIAS, 2008).

Segundo Bresser:
A Nova Gestão Pública ou "revolução gerencial" é um dos movimentos mais recorrentes e atualmente discutidos em todo o mundo, tendo surgido na segunda metade do século XX como alternativa para superar os problemas causados pelas chamadas buropatologias estatais associado à incapacidade de os governos atuarem com eficácia, eficiência e efetividade em determinados setores da economia. (BRESSER PEREIRA, 1998)

Kettl (2008) analisou as mudanças e reformas fundamentadas na modernização do Estado e propagadas pelo movimento da Nova Gestão Pública - aplicadas no governo brasileiro quando Bresser Pereira foi o Ministro do Planejamento, Orçamento e Gestão, no governo Fernando Henrique - que ampliaram a força do gestor local e o poder da máquina burocrática na execução de políticas públicas, buscando a eficiência. 
No mesmo caminho, em 1997, o governo do Estado de São Paulo inaugurava a primeira unidade do Poupatempo, uma central de atendimento que colocava os departamentos de diversos órgãos correlatos em um único local, a exemplo do que era realizado em outros estados e municípios pelo Brasil afora. O Poupatempo revolucionou o atendimento ao cidadão de tal forma que se tornou sinônimo de eficiência e um modelo a ser copiado por todo o país (DIAS, 2008).

O uso intensivo de tecnologia da informação ampliou a responsabilização, o que permitiu também o controle popular através do conceito de transparência pública. Por outro lado, isso também influiu no poder do Estado sobre o cidadão: "a eficiência do Estado conduziu para um maior controle da população sobre o Estado, ampliando a participação democrática, mas também para um maior controle do Estado sobre a população, diminuindo liberdades individuais" (KETTL, 2008). Se por um lado esses mecanismos de modernização tornavam o Estado mais ágil ao transferir decisões, outrora centralizadas, para a periferia do sistema, por outro ampliavam a necessidade de uma forma mais clara de fiscalização gerencial.

No mundo, a sociedade migrava de industrial para uma sociedade em rede (CASTELLS, 2010). No início do século XXI, não bastavam a eficiência, eficácia e efetividade das ações governamentais, nem uma transparência sob demanda. Os cidadãos aprendiam que podiam exercer seus direitos e exigiam mais agilidade dos governos e mais espaço para participação. Conciliar os anseios populares com as necessidades do Estado, cada vez mais exigindo serviços realizados com qualidade e com uso de menos recursos, passou de ser uma necessidade para se tornar uma nova obrigação. Conforme Moura:

\begin{abstract}
As estruturas anacrônicas, piramidais e centralizadas no topo, típicas das organizações da era industrial, produzem intermináveis disputas interburocráticas pelo controle de mais e mais decisões que nada decidem, causando desperdício de tempo e dinheiro públicos e gerando efeitos secundários adversos, às vezes piores do que a tentativa inicial de solucionar o problema de origem. A realidade muda muito rapidamente e as informações circulam de forma muito mais veloz do que as decisões governamentais podem gerar efeitos. Ou as decisões vêm tarde demais, ou caem o impasse paralisante. Flexibilidade, agilidade, criatividade e velocidade cada vez mais se impõem sobre a ineficiência burocrática.
\end{abstract} (MOURA, 2007).

Sem o devido controle ficava difícil garantir que as decisões tomadas pelos gestores seriam compatíveis com as diretrizes do governante e os interesses globais da sociedade. 
Os governos democráticos necessitavam de regras que definissem sua atuação para que houvesse uma fiscalização mais objetiva por parte da população, o que gerou um sistema de responsabilização, ou "Accountability", garantindo a fidelidade das ações às diretrizes centrais dos programas e o aprimoramento da atuação do Estado com a adequação de ações à realidade local. O termo Accountability, que não possui tradução precisa para o português, representa uma série de atividades que levam a responsabilizar o gestor pelos seus atos (por isso o neologismo responsabilização), mas, além disso, significa registrar as informações que permitam acompanhar as atividades a serem gerenciadas, bem como é ferramenta essencial para auxiliar na boa governança. O termo vem da contabilidade, originário de um censo econômico realizado em 1085, na Inglaterra. (BOVENS, 2007)

Bovens (2007) deixou mais claro o conceito de Accountability ao apresentar quem responsabiliza (superiores, políticos, tribunais, auditores, inspetores, controladores e pares - ordem dos advogados, por exemplo), quem é responsabilizado (corporações, condutores, todos ou um agente específico) e os mecanismos de responsabilização (como a Lei $\mathrm{n}^{\circ} 8.666$ de 21 de junho de 1993, que regulou as compras públicas estabelecendo o formato das licitações, a Lei Complementar $n^{\circ} 101$ de 04 de maio de 2000, que estabeleceu parâmetros para a responsabilização fiscal de governantes e a Lei Complementar $n^{\circ} 131$ de 27 de maio de 2009, que definiu a transparência das informações financeiras na Internet).

Assim, se por um lado o governo pôde economizar recursos ampliando sua eficiência e eficácia, a falta de confiança nas estruturas públicas levou os cidadãos a defenderem um maior engessamento legal, como forma de se protegerem contra a ingerência de poder por parte dos governantes. Uma demonstração sintomática dessa descrença é o fato de que a melhoria na renda do trabalhador brasileiro levou a um aumento considerável na demanda por ensino privado, ou seja, os trabalhadores que conseguem ter renda suficiente para pagar uma instituição privada de ensino estão preferindo esta opção a buscar melhorias na escola onde as crianças já estudam, demonstrando uma descrença de que a instituição possa melhorar a curto ou médio prazo (TAKAHASHI, 2010).

Em paralelo ao controle institucionalizado, a popularização das redes sociais na primeira década do novo milênio criava novos canais de relacionamento e participação, que passaram a ser usados não apenas para diversão, mas como forma de protesto contra serviços ruins de empresas e de governos e para mobilizar ações. Segundo Marques: 
O público dessas redes digitais está cada vez mais consciente das ideias democráticas, da transparência e da responsabilidade. Esses internautas estão aproveitando, a todo momento, os pequenos espaços e estão avançando. Nem todas as cruzadas são de interesse publico, mas algumas campanhas na web parecem estar surtindo bons resultados (MARQUES, 2009).

\subsection{A Sociedade em rede}

A sociedade contemporânea não é mais um elemento estático. Antes, está em constante mutação e, assim, está inserida num processo de mudança no qual os principais fatores de aceleração são as novas tecnologias. Esta mudança de paradigma social, só comparável com as mudanças que geraram a sociedade agrícola e posteriormente a industrial, foi chamada de pós-industrial ou da informação (BELL, 1978), terceira onda (TOFFLER, 1995), sociedade pós-capitalista ou do conhecimento (DRUCKER, 1994), da pósinformação ou digital (NEGROPONTE, 1995).

Castells (2010) cita que "nosso mundo está em processo de transformação estrutural há duas décadas. É um processo multidimensional, mas está associado à emergência de um novo paradigma tecnológico, baseado nas tecnologias de comunicação e informação, que começaram a tomar forma nos anos 60". Neste ambiente surge uma sociedade que tem sido caracterizada como sociedade de informação ou sociedade do conhecimento, terminologias com as quais o autor não concorda, pelo fato da busca do conhecimento e da informação ser, há séculos, uma obsessão da sociedade. Neste sentido, o que ele entende ser efetivamente diferencial é a mudança para uma "Sociedade em Rede".

Na visão de Castells (2010), essa sociedade em rede se moldou graças às comunicações globais, por meio das quais o conhecimento e a informação chegam a países de todo o planeta, mudando a forma de relacionamento, criando redes globais de capital, bens, serviços, ciência e tecnologia, de relacionamentos pessoais e tudo o mais que é denominado globalização.

Independente da nomenclatura fica claro que o novo modelo organizacional das sociedades se assenta num modo de desenvolvimento social e econômico em que a informação, como meio de criação de conhecimento e valor, desempenha um papel fundamental na produção de riqueza e na contribuição para o bem-estar e qualidade de vida dos cidadãos. A economia também é afetada pelo processo, o modelo globalizado 
cria uma condição de maior competitividade que exige melhor desempenho profissional e flexibilidade.

Para Kohls (1999) a Sociedade em Rede está sendo moldada dentro de uma revolução centrada nas tecnologias da informação, em ritmo acelerado. Pela primeira vez na história, segundo Kohls (1999), a mente humana é uma força direta de produção e não apenas um elemento decisivo no sistema produtivo. Assim, computadores e sistemas de comunicação são todos amplificadores e extensões da mente humana. Nesse ambiente, o Estado tem um papel importante na Sociedade em Rede, pois, se por um lado pode ser a principal força de inovação, por outro, pode afastar totalmente seus interesses do desenvolvimento tecnológico ou se torna incapaz de promovê-lo, levando à estagnação e prejudicando a sociedade (KOHLS, 1999). Para tentar evitar esta segunda situação, os governos passaram a trabalhar fortemente na implantação de seus governos eletrônicos.

Conforme Medeiros (2004) os governos de distintos países precisaram adaptar-se a novas realidades, como a globalização e a era do conhecimento, que moldam a Sociedade da Informação. Neste contexto, as tecnologias de informação e comunicação têm papel crucial no modo como o Estado cumpre suas principais funções. Medeiros conclui que tais tecnologias mudaram a abordagem da gestão pública, pois cidadãos, empresas e demais organizações demonstraram a necessidade de ter acesso ao governo de modo cada vez mais rápido e facilitado, bem como de que os programas governamentais atendessem às suas atuais necessidades. Para atender estes anseios o Estado se informatizou, dando origem ao Governo Eletrônico.

\subsection{O Governo Eletrônico}

O Governo Eletrônico, também conhecido como e-governo, ou sinteticamente e-gov, é definido pelo Gartner Group como "a contínua otimização de oferta de serviço público, participação do cidadão e governança do Estado mediante transformação de relacionamentos internos e externos com uso da tecnologia, da internet e da nova mídia". (ONU/ASPA, 2001).

Apropriar a tecnologia para atender aos anseios dos cidadãos era exatamente a necessidade dos governos, que viam as tecnologias assumir um papel cada vez mais relevante em suas economias. De acordo com Campos e Marques (2006), desprezar a 
influência das tecnologias levaria a um prejuízo irreversível para o desenvolvimento. Por outro lado, perceber as oportunidades geradas pelo intenso uso de tecnologias na prestação de serviços alavancaria o desenvolvimento, gerando facilidades para empresas e cidadãos, eliminando burocracias e facilitando o acesso a serviços. As políticas públicas devem possibilitar o acesso amplo às facilidades tecnológicas, centrando os serviços no cliente (cidadãos e sociedade) de forma a potencializar a geração de valor, a partilha do conhecimento, o aumento de produtividade e a transparência.

Em complemento, Coelho (2001) considera que o enfrentamento das antigas estruturas burocráticas, políticas e metodológicas leva à melhoria da administração pública, viabilizando uma administração moderna voltada aos interesses dos cidadãos. A sociedade em rede permite que governos funcionem vinte e quatro horas por dia, divulgando informações transparentes e prestando serviços de maneira rápida, com menores custos, maior qualidade e de forma mais eficiente.

Conforme Murru (2003), é obrigação do Governo Eletrônico permitir o acompanhamento dos governos pelos cidadãos (transparência), tornar possível a participação nos processos decisórios (e-democracia), oferecer melhor acesso aos serviços públicos (aumentando a produtividade e eficiência do Estado) e coordenar ações dos governos central, regional e local. No entanto, é necessária a simplificação dos serviços, a eliminação da hierarquia de gestão no governo e a melhoria contínua de processos, com a redução de sistemas redundantes, para que o governo possa garantir uma rápida resposta ao cidadão.

Mora (2005) cita o Terceiro Fórum Global em Reinvenção de Governo, ocorrido em 2001, no qual se chegou a um consenso quanto ao potencial do Governo Eletrônico para melhorar a qualidade de vida dos cidadãos, uma vez que a prática do mesmo pode gerar redução de recursos financeiros e de tempo despendidos, bem como fortalecer a capacidade institucional, melhorando a oferta de serviços e reduzindo a corrupção através de maior transparência e controle social, além de desempenhar o papel de disseminador de novas tecnologias entre a sociedade civil e empresarial. Pelas suas consequências positivas, o Governo Eletrônico revelou-se um importante instrumento no processo de modernização do Estado.

Na visão de Knight, Fernandes e Cunha (2007), o Governo Eletrônico “assimila o potencial das Tecnologias da Informação e Comunicação na transformação da administração pública, com substancial melhoria da sua organização, dos seus serviços e 
do relacionamento com a sociedade", inserindo-se em uma perspectiva participação do cidadão que leva à governança democrática.

Para Wauters (2010) a evolução do Governo Eletrônico se associa à inovação, a partir da evolução tecnológica, e a uma maior compreensão, para atender às necessidades dos cidadãos. $\mathrm{O}$ cidadão espera por serviços simples e fáceis de serem solicitados, que sejam rápidos, flexíveis, e oferecidos em horários convenientes e, quando se fizer necessária uma interação presencial com agentes públicos, o cidadão deseja ser corretamente informado de maneira que não haja retornos desnecessários. O governo deve estar "antenado" às mudanças tecnológicas de forma a se antecipar e incorporar as inovações geradas pelas mesmas, como as redes sociais, a popularização dos smartphones, o conceito de recomendações de usuários e dos sistemas de indicação de reputação (que podem servir como ferramentas auxiliares na fiscalização de serviços terceirizados). No desenvolvimento, deve-se pensar na utilização de elementos modulares que permitam o reuso, bem como no compartilhamento de códigos. Os sistemas podem ser continuamente incrementados com novas facilidades, que podem definir os níveis de sofisticação de um governo eletrônico.

Yildiz (2007) categoriza o Governo Eletrônico com base nos relacionamentos:

G2G - Governo com Governo: sistemas de relações entre entes governamentais somente;

G2C - Governo com Cidadão: trata dos sistemas que viabilizam o relacionamento do Governo com o cidadão;

G2B - Governo com empresas: sistemas de relação entre Governo e iniciativa privada;

G2SC - Governo com Terceiro Setor: sistemas que trabalham as relações do Governo com entidades do Terceiro Setor; e

C2C - Cidadão com Cidadão: sistemas que permitem a interação direta entre cidadãos, mantidos pelos governos para este fim.

Ferrer et al. (2004) apresenta cinco diferentes níveis de sofisticação tecnológica para o desenvolvimento do Governo Eletrônico:

1) Institucional: provisão de informações à comunidade;

2) Transacional: serviços oferecidos virtualmente pelo governo, com ou sem uma transação financeira; 
3) Colaborativo: o portal direciona o cidadão às suas demandas;

4) Integrado: os dados necessários para uma transação ou andamento de um processo administrativo encontram-se integrados na base de dados do governo;

5) Personalização: interação do cidadão com o governo de forma personalizada e customizada;

Uma vez que os serviços de governo já são oferecidos de forma eletrônica transacional e se encontram integrados, não somente entre as esferas de um mesmo poder, mas também entre os poderes, elimina-se toda a cadeia formal que a estrutura hierárquica produz. Isto pode ser conseguido com a interoperabilidade entre os sistemas, através de uma camada de integração, possibilitando a apresentação de um portal único pelo qual todos os governados possam ter acesso a todos os serviços já na forma de transação, sendo esta a meta a ser atingida por todos os governos.

Nos últimos 20 anos, a expansão do Governo Eletrônico em diversos países, inclusive no Brasil, trouxe a melhoria do relacionamento do Estado com o cidadão. Diniz (2005) apresenta a evolução da tecnologia da informação na gestão pública brasileira, que pode ser dividida em três fases, organizadas segundo os focos predominantes nas aplicações desenvolvidas. Em cada fase, novas prioridades foram dominando a cena de acordo com as políticas em vigor ou em decorrência do amadurecimento de uma determinada tecnologia. De 1970 a 1992, o foco foram as aplicações voltadas para a melhoria da gestão interna e mais eficiência nos processos administrativos financeiros. De 1993 a 1998, o foco voltou-se para aplicações e processos para apoiar a prestação de serviços ao cidadão pessoalmente ou via telefone e, a partir de 1999, direcionou-se o foco para serviços via internet.

Por se tratar de uma mudança global, o Brasil está totalmente inserido no processo de transformação para uma sociedade em rede ou do conhecimento. Segundo Takahashi (2000) “[...] em cada país, a sociedade da informação está sendo construída em meio a diferentes condições e projetos de desenvolvimento social, segundo estratégias moldadas de acordo com cada contexto”. Ele demonstrou preocupação em garantir a evolução, no Brasil, para uma efetiva sociedade da informação quando afirmou que "[...] ao Brasil urge acelerar o processo de articulação efetiva de um programa nacional para a sociedade da informação". Para Takahashi, o governo e a sociedade brasileira devem trabalhar em conjunto para que esta nova sociedade seja desenvolvida dentro de princípios tais como a 
preservação da identidade cultural do país, a sustentabilidade - respeitando as diferenças regionais - e a efetiva participação social para garantir a democracia política.

O Governo Eletrônico passou a ter destaque no Brasil a partir de 2000, quando os trabalhos para evitar o bug do milênio mobilizaram e aproximaram os responsáveis por Tecnologia da Informação nos governos (DINIZ, BARBOSA, et al., 2009). O compartilhamento de informações e a soma de esforços se mostraram viáveis mesmo entre governos opositores, mostrando que podiam trabalhar juntos.

De 2000 à 2002 o governo eletrônico brasileiro se desenvolveu, ficando em $4^{\circ}$ lugar na América latina e em $21^{\circ}$ no ranking mundial, segundo a ONU (HAFEEZ, 2003). Nos períodos seguintes o Brasil caiu várias posições no Ranking de governo eletrônico, o que torna evidente que a velocidade com que adotamos as tecnologias é inferior à de diversos outros países. O gráfico abaixo mostra a evolução do Brasil no ranking mundial:

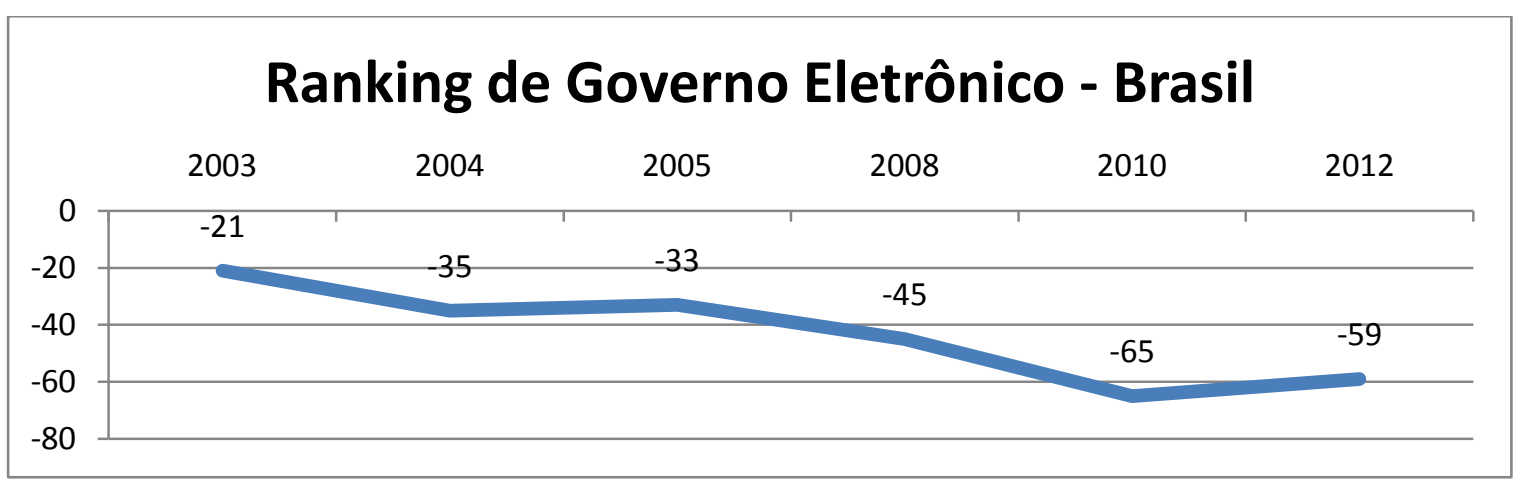

Gráfico 1: Ranking brasileiro de governo eletrônico

Bertucci coordenou os estudos das Nações Unidas em 2005 e 2008, focando principalmente as relações do governo com o cidadão e as relações entre os órgãos da administração pública, sendo este índice composto de indicadores do uso da Internet e da rede de computadores, da estrutura de telecomunicações e o do capital humano das organizações.

No caso do indicador de uso da internet e da rede de computadores, Bertucci (2008) qualificou os governos em cinco estágios de desenvolvimento:

No primeiro estágio, denominado emergente, o governo possui uma presença na internet apenas com conteúdos informativos e sítios oficiais, com links para os diversos departamentos e órgãos que compõem a administração, sendo a maioria do conteúdo estática e com pouquíssima interação com o cidadão. 
No segundo estágio, o avançado, o governo provê mais informação de políticas públicas onde a informação é mais facilmente acessada pelo cidadão.

No terceiro estágio, o interativo, o governo passa a prestar serviços on-line, tais como imprimir formulários para pagamento de taxas ou que simplifiquem o serviço presencial que o cidadão precisa receber.

No quarto estágio, o transacional, a interação passa a ser de duas vias, com interações entre o cidadão e o governo, e incluem-se serviços do tipo de pagamento de taxas, solicitação de serviços, documentos e renovações de licenças, sendo que estes serviços passam a funcionar todos os dias, vinte e quatro horas.

Finalmente, no quinto estágio, o conectado, todas as organizações do governo são enxergadas pelo cidadão como conectadas em uma entidade única, com uma infraestrutura integrada para o cidadão, as empresas, o terceiro setor e as diversas esferas de governo.

Para o indicador de infraestrutura de telecomunicações, o índice é composto de critérios que mensuram a capacidade do país em prover serviços. Estes critérios são avaliados sempre tomando como base o total da população do país, proporção de usuários de internet, de computadores, linhas telefônicas, aparelhos celulares e banda larga.

Para o indicador de capital humano, avalia-se a proporção de pessoas do país que está preparada para o uso da informática e pela taxa de escolaridade da população, usando parâmetros definidos pela UNESCO.

Para a ONU, o governo evoluído deve atender a sociedade de forma totalmente integrada e consolidada. A evolução iniciou-se a partir de um governo tradicional, como era operado antes dos anos 90, passando para o uso intensivo do governo eletrônico, para culminar no próximo patamar, que consiste em um governo eletrônico conectado, com as suas estruturas organizacionais integradas, oferecendo serviços de valor focado no cidadão. Este governo conectado através das Tecnologias da Informação e Comunicação traz diversos benefícios. Internamente, o Governo reduz as duplicações, diminui os custos de transações, simplifica os processos, aumenta a eficiência, aumenta o compartilhamento de informação, coordenação e comunicação e melhora a transparência. Sob a ótica da sociedade, oferece serviços mais rápidos, com mais eficácia, mais flexibilidade, traz inovação e aumenta a participação do cidadão e sua satisfação. 
Qian (2010) atualizou o estudo em 2010 e novamente em 2012, figurando o Brasil em $61^{\circ}$ lugar, comprovando a necessidade de avanços para que o país se desenvolva ainda mais no que se refere a governo eletrônico. Para tanto, é necessário tornar o governo brasileiro ainda mais conectado e integrado. No relatório de 2010 foi ressaltada a iniciativa do governo do estado de São Paulo de integrar os serviços públicos em um único site, proposto pelo modelo de interoperabilidade; até então, porém, o Brasil apenas caía no ranking (QIAN, 2012).

A tabela a seguir mostra uma seleção de países e sua classificação no "E-Government Readiness Index”, de 2012:

Tabela 1: E-government Readiness Index

\begin{tabular}{|l|l|c|}
\hline CLASSIFICAÇÃO & PAÍS & E-Government Readiness Index \\
\hline 1 & CORÉIA DO SUL & 0,9283 \\
\hline 2 & HOLANDA & 0,9125 \\
\hline 3 & REINO UNIDO & 0,8960 \\
\hline 4 & DINAMARCA & 0,8889 \\
\hline 5 & ESTADOS UNIDOS & 0,8687 \\
\hline 6 & FRANÇA & 0,8635 \\
\hline 7 & SUIÇA & 0,8599 \\
\hline 8 & NORUEGA & 0,8593 \\
\hline 9 & FINLANDIA & 0,8505 \\
\hline 10 & SINGAPURA & 0,8474 \\
\hline 11 & CANADÁ & 0,8430 \\
\hline 12 & AUSTRÁLIA & 0,8390 \\
\hline 27 & RÚSSIA & 0,7345 \\
\hline 39 & CHILE & 0,6769 \\
\hline 43 & COLÔMBIA & 0,6572 \\
\hline 50 & URUGUAI & 0,6315 \\
\hline 56 & ARGENTINA & 0,6228 \\
\hline 59 & BRASIL & 0,6167 \\
\hline 78 & CHINA & 0,5359 \\
\hline
\end{tabular}

Fonte: Adaptado de Qian, 2012

Na pesquisa de 2012 percebe-se ligeira melhora do posicionamento do Brasil, talvez fruto da aprovação pelo Congresso e da sanção presidencial da Lei de Informação Pública, que implica na obrigação, aos municípios, de divulgar todas as contas públicas para os cidadãos acessarem, em formato aberto e passível de análise, na Internet. Isso significa que um esforço de integração das informações financeiras passa a ser prioritário para o cumprimento da lei, o que pode significar ampliação dos esforços na interoperação de sistemas em 2012 e 2013.

Um estudo, realizado pelo Comitê Gestor da Internet sobre o governo eletrônico no Brasil em 2010, mostra que a sociedade brasileira quer acessar o Governo através de meios 
eletrônicos. Nas entrevistas realizadas pelo estudo, a grande maioria dos usuários de internet $(93 \%)$ declarara estar propensa a utilizar a internet para acessar serviços do governo (CGI-BR, 2010).

O mesmo estudo identificou que existe uma demanda latente quanto ao uso de serviços do governo via internet. Os cidadãos que já utilizam a internet em seu dia a dia, considerados incluídos digitalmente, querem utilizá-la cada vez mais como meio de se relacionar com o governo. Porém, não existem tantos serviços disponíveis on-line.

A imensa maioria declara que optaria pela internet como forma de acesso aos serviços do governo, caso estivessem disponíveis. Este fato só vem a confirmar que a população brasileira já aderiu à ideia de sociedade em rede e, portanto, o setor público deve estar atento para atender adequadamente à sua população. Analisando os dados do mesmo estudo do Comitê Gestor da Internet no Brasil de 2008, Barbosa, Cappi e Gatto afirmaram:

De acordo com a pesquisa do CGI.br, que monitora a evolução do uso de serviços públicos eletrônicos e o uso do governo eletrônico no Brasil, temos que apenas $22 \%$ da população brasileira já fez algum tipo de uso desses serviços, sendo $25 \%$ da população urbana e $7 \%$ na área rural. Isso demonstra que, embora o governo eletrônico esteja avançando na oferta de serviços públicos eletrônicos, a população brasileira ainda não faz uso efetivo de toda a sua potencialidade. Quando olhamos, por exemplo, para as camadas sociais de menor poder aquisitivo e de baixa renda familiar, essas são as que menos utilizam esses serviços quando necessitam interagir com instituições governamentais, e são as mais populosas. (BARBOSA, CAPPI e GATTO, 2009)

Na contramão da ineficiência estatal, o uso das redes pelas empresas e sociedade civil criou um novo termo, "socialnomics", a economia das redes sociais (QUALMAN, 2009). Com as possibilidades de participação na rede, o cidadão deixa de ser mero expectador das ações para ser protagonista, criticando, divulgando, elogiando e intervindo. Assim, as instituições não governamentais, que trabalham as questões públicas paralelamente aos governos, estão modificando seus mecanismos de atuação, de forma a se inserirem na Sociedade em Rede.

Exemplos são: a criação de espaços virtuais especializados em discussões públicas, como o site "Cidade Democrática" (INSTITUTO SEVA, 2010), desenvolvido por jovens cidadãos de São Paulo, e a realização de consultas públicas e referendos virtuais, prática 
comum na Anatel - Agência Nacional de Telecomunicações - que mantém um espaço permanente na Internet para consultas públicas, no qual o cidadão ou empresas podem opinar sobre as novas resoluções da agência, inserindo o governo no novo modelo (ANATEL, 2010). Com o uso intensivo da Tecnologia da Informação, os debates se tornam atemporais, permitindo que as pessoas participem sem interferir na produtividade do Estado. Assim, a eficiência não é mais prejudicada e a eficácia, pelo conhecimento compartilhado pelos cidadãos, pode aumentar.

A questão se torna maior quando se verifica que nas políticas públicas, mesmo definidas as responsabilidades, permeiam-se ações nos três níveis de poder: federal, estadual e municipal. Como exemplo, podemos citar a questão da segurança, apontada como o principal problema para os brasileiros em pesquisa da CNI/IBOPE (2011). O número de policiais é limitado, pois os recursos orçamentários para contratação também o são. Além disso, a polícia é estadual, mas, como disse Franco Montoro, "ninguém mora na União, ninguém mora no Estado, todos moram no município", as ocorrências geram implicações nas administrações municipais. Para enfrentar o problema, vários municípios montaram guardas municipais (grupamentos, armados ou não, responsáveis por garantir a integridade do patrimônio público no município, mas que muitas vezes acabam extrapolando as ações, atuando com poder de polícia) e estão ampliando a instalação de câmeras de segurança públicas que monitoram boa parte do espaço público (KANASHIRO, 2006). Outra ação é a criação de salas de situação, espaços informatizados que recebem informações em tempo real, agrupadas de diversos órgãos, gerando subsídios para a atuação governamental (ICI, 2011).

Como lembrado por Kettl (2008), se por um lado tais mecanismos ampliam a eficiência do poder público no controle da segurança, por outro a privacidade dos cidadãos se torna restrita. O grande irmão de George Orwell se concretiza, pois somos vigiados constantemente. Torna-se cada vez mais tênue a separação entre controle e democracia, sendo os dois extremamente necessários para garantir a preservação de liberdades individuais e coletivas.

Outra faceta se apresenta na integração de sistemas sociais, com o compartilhamento de informações entre os sistemas de informação de educação, saúde, assistência social, segurança, transporte público, etc. Uma das dificuldades técnicas para a integração dos sistemas é o fato de empresas e pessoas possuírem múltiplos cadastros, não necessariamente com as mesmas informações, em diferentes bancos de dados. Para 
combater o problema, em 1997 o Governo Federal aprovou a criação do documento único (Lei 9.454, 1997), que uniria RG, CPF, título de eleitor e habilitação para dirigir, em um único documento. Em 2009, a lei foi reeditada e regulamentada (Lei 12.058, 2009) e a produção do novo documento teve início em 2010. Atualmente, tramita no congresso legislação para acrescentar o Passaporte no rol de documentos a serem unificados.

Segundo Doneda (2009), com essa iniciativa, a identificação de um cidadão será mais efetiva, pois com a unificação as pessoas não terão vários registros gerais (pois a emissão é estadual) nem Cadastros de Pessoa Física diferentes. Endereços, telefones e outras formas de contato ou localização do indivíduo poderão ser integrados e acessados facilmente para fins de segurança ou sociais. Mas, uma dificuldade deste tipo de integração é o fato dos processos não dependerem de apenas uma instância de poder, mas perpassarem por responsabilidades municipais, estaduais e federais. Há que se entender o novo paradigma de gestão pública de resultados da NGP e o governo eletrônico dentro destes processos. 


\section{REVISÃO DA LITERATURA}

Ciência é feita de fatos, como uma casa é feita de pedras, mas um acúmulo de fatos não é mais ciência do que um monte de pedras é uma casa.

Henri Poincaré

\subsection{Interoperabilidade e padronização de dados}

Em 1948, o embargo da União Soviética a Berlim Oriental originou a ponte aérea de Berlim, onde Grã-Bretanha e Estados Unidos forneciam suprimentos para a cidade. Para gerenciar a miríade de documentos de diferentes fornecedores em diferentes línguas foi criado o standard manifest, um padrão de troca de informações comerciais para unificar a apresentação de notas de mercadorias e permitir um controle mais eficiente das compras e entregas (DRUMMOND e MORROW, 2007). O conceito de interoperabilidade surgia, para descrever a troca de informações entre sistemas diferentes (não necessariamente informatizados) por meio de padrões, de forma que estes pudessem intercambiar dados de forma facilitada.

Em 1960 a companhia aérea America Airlines começou a instalar o primeiro sistema mundial de emissão de passagens informatizado, o SABRE, que entrou no ar em 1964. Este sistema demonstrou a capacidade de comunicação e troca de dados por meio de redes eletrônicas funcionando com padrões de comunicação entre diferentes terminais e um repositório central de informações acessado em todo o mundo (O'DELL, 2010), sendo o percursos dos sistemas em rede e provando que a solução era viável comercialmente.

Em 1968 foi formado nos Estados Unidos o Transportation Data Coordinating Committee (TDCC), que desenvolveu o EDI (Eletronic Data Interchange) a partir da unificação de quatro padrões já existentes na indústria. Alguns anos depois os padrões foram gradualmente sendo trocados pelos da American National Standards Institute (ANSI), sendo o padrão X12 um dos marcos deste período. Na década de 80 os padrões foram internacionalizados com a formação da United Nations Electronic Data Interchange for Administration, Commerce and Transport (UN/EDIFACT). A definição de padrões internacionais já existia desde 1906 com a criação da IEC (International 
Electro technical Commission), e se ampliou em 1947 com a criação da ISO (International Standards Organization). Dentro da ISO está estabelecido um comitê específico sobre Interoperabilidade Técnica, o TC 46/SC 4 (ISO, 2010).

Em paralelo, uma agência de pesquisa do departamento de defesa do governo americano denominada Advanced Research Project Agency (ARPA), renomeada para DARPA em propôs em 1967, em uma reunião da Association for Computer Machinery (ACM) o desenvolvimento de uma rede para interligar os diversos pesquisadores que participavam da agência para que pudessem compartilhar informações entre si, reduzindo custos e esforços duplicados. A ideia era que um computador de qualquer fabricante (chamado host) se interligaria com um computador especializado (IMP, do inglês Interface Message Processor) que se conectaria com outros IMPs conectados a hosts. Em 1969 quatro nós estavam conectados, originando a ARPANET (FOROUZAN e CHUNG, 2008). A ARPANET utilizava um protocolo de comunicação para interligar os IMPs com os hosts, denominado NCP (Network Control Protocol). Em 1973 uma equipe de pesquisadores coordenada por Vinton Cerf no SRI (Stanford) e Robert Kahn na ARPA desenvolveram um conjunto de protocolos que assegurava a interoperabilidade e interconexão de redes diversas, denominado TCP/IP, que substituiu totalmente o NCP em 1983 (ALMEIDA, 2005). A possibilidade de interligar redes diversas levou á rápida expansão da rede original, dando origem à Internet. O protocolo TCP/IP foi modernizado e hoje é a base para acesso à Internet e diversas outras redes entre computadores.

Com a evolução da tecnologia da informação diversos sistemas passaram a ser criados, gerando grandes repositórios de dados independentes. Em 1995, os participantes de um evento técnico ocorrido na cidade de Dublin, nos Estados Unidos, compreendendo a importância de existirem padrões para a troca de dados, criaram uma organização denominada Dublin Core Metadata Initiative (DCMI, 2012), dedicada a promover a adoção de padrões de metadados para interoperabilidade e desenvolver vocabulários especializados para sistemas de informação. O padrão Dublin Core, resultante desta iniciativa, é um esquema de metadados que descreve objetos digitais, como vídeos, sons, imagens, textos e sites na web. Por ser amplamente utilizado, foi reconhecido pela ISO como um padrão de fato, recebendo a certificação ISO 15836:2003.

Para Souza, Vendrusculo e Melo (2000), metadados descrevem os atributos e o conteúdo de um documento original de forma efetiva, viabilizando o acesso à informação precisa. Assim, o Dublin Core pode ser definido como sendo o conjunto de elementos de 
metadados planejado para facilitar a descrição de recursos eletrônicos. É a catalogação do dado ou descrição do recurso eletrônico, essencial para a geração de interoperabilidade.

Mesmo o Dublin Core sendo um padrão muito aceito, ainda há a necessidade de descritores mais avançados. A Interoperabilidade de sistemas está sempre em mutação, sendo que padrões são definidos e descartados continuamente, acompanhando a evolução do próprio desenvolvimento tecnológico mundial.

\subsubsection{Interoperabilidade Governamental}

A relevância da interoperabilidade em governo na área de sistemas acompanhou o desenvolvimento do governo eletrônico, no qual a troca de informações, conforme já apresentado, visa melhorar a atuação governamental.

Conforme Sanchez, Janowski e Estevez (2008), as organizações do setor público foram pensadas através de unidades organizacionais isoladas, com orçamento e recursos próprios, sendo responsáveis por atingir sua missão particular. Sob a ótica do governo integrado, a desvantagem é a ineficiência decorrente da existência de processos duplicados em várias agências, com os mesmos dados sendo prestados com base na estrutura de governo e conveniência, ao invés de atender as necessidades dos cidadãos. Em resposta à pressão da sociedade, os governos atuaram na reforma do setor público e no Governo Eletrônico. Isso significou introduzir mudanças estruturais e de processos, como: criar agências colaboradoras, desenvolver ações coordenadas, descentralizar decisões do governo, terceirizar parte do serviço público, compartilhar informações, ter uma maior utilização de recursos comuns e abordar os problemas de forma colaborativa e em rede. Para tanto, a interoperabilidade mostrou ser um dos principais facilitadores das organizações, permitindo sistemas integrados em rede.

Há diversas formas de apresentar a mesma definição sobre o que é interoperabilidade, sendo que são apresentadas diversas definições globais no portal de Governo Eletrônico brasileiro, na página que divulga o padrão de interoperabilidade para o país, a e-Ping (GOVERNO FEDERAL, 2012):

Intercâmbio coerente de informações e serviços entre sistemas. Deve possibilitar a substituição de qualquer componente ou produto usado nos pontos de interligação por outro 
de especificação similar, sem comprometimento das funcionalidades do sistema. (Reino Unido);

Habilidade de transferir e utilizar informações de maneira uniforme e eficiente entre várias organizações e sistemas de informação. (Austrália);

Habilidade de dois ou mais sistemas (computadores, meios de comunicação, redes, software e outros componentes de tecnologia da informação) de interagir e de intercambiar dados de acordo com um método definido, de forma a obter os resultados esperados. (ISO);

Interoperabilidade se define por dois componentes de um sistema, desenvolvidos com ferramentas diferentes, de fornecedores diferentes, que podem ou não atuar em conjunto. (Lichun Wang, Instituto Europeu de Informática - Corba Workshops);

Para Sanchez, Janowski e Estevez (2008), interoperabilidade governamental é a capacidade dos sistemas de tecnologia da informação e comunicação e dos processos de negócios, de compartilhar informações e conhecimentos dentro e através das fronteiras organizacionais, a fim de melhor apoiar a prestação de serviços públicos, reforçando o apoio às políticas públicas e aos processos democráticos.

Pardo e Burke (2008) consideram a interoperabilidade em governo um mix de políticas de gerenciamento e competências tecnológicas necessárias para que uma rede de organizações possa fornecer programas e serviços de governo de maneira coordenada.

Para Santos (2004), a interoperabilidade entre os serviços de governo é uma das mais importantes linhas de ação estratégica no desenvolvimento do governo eletrônico e tem sido adotada pelos países mais avançados nessa área, podendo ser descrita como "uma cadeia de protocolos, padrões e especificações técnicas que permita a interligação envolvendo os fluxos de informação e os sistemas de computação dentro das organizações e entre elas, abrangendo a administração pública, as empresas e os cidadãos". Assim, a interoperabilidade permite a troca de informações de acordo com os fluxos de trabalho definidos em um processo independente dos sistemas envolvidos, uma vez que, a partir da aplicação de diretrizes e especificações dos registros, ela torna possível a transferência de informações entre os sistemas e bancos de dados, contemplando tecnologias heterogêneas de programação, redes ou equipamentos. "Propicia o equacionamento de uma utilização otimizada da diversidade de componentes 
e produtos provenientes de múltiplos fornecedores e frequentemente caracterizados por acentuada heterogeneidade tecnológica." (SANTOS, 2004)

Para Santos, Corte e Motta (2006), "um governo moderno, integrado e eficiente exige sistemas igualmente modernos, integrados e interoperáveis, trabalhando de forma íntegra, segura e coerente em todo o setor público". Neste contexto, a interoperabilidade de tecnologia, processos, informação e dados é condição vital para o provimento de serviços de qualidade, tornando-se premissa para governos em todo o mundo, como fundamento para os conceitos de governo eletrônico. A interoperabilidade permite racionalizar investimentos em tecnologias da informação e comunicação, por meio de compartilhamento, reuso e intercâmbio de recursos tecnológicos.

A definição da ISO já citada resume e, ao mesmo tempo, abarca as definições levantadas, sendo adotada por Santos (2008) e compartilhada por Mesquita e Bretas (2010, p. 25). Focando, pode-se definir interoperabilidade entre sistemas governamentais como: a habilidade de dois ou mais sistemas utilizados por instituições públicas, ou envolvidos com atividades consideradas do primeiro setor (educação, saúde, segurança, transporte público, etc.) interagirem e intercambiarem dados, de acordo com um método definido, de forma a obter os resultados esperados. Esta será a definição adotada para este trabalho.

\subsubsection{Padrões estruturados para a interoperabilidade de sistemas}

De acordo com Rogério Santana dos Santos (2004), os padrões de interoperabilidade são essenciais para o desenvolvimento e aprofundamento de projetos e ações de governo eletrônico, com diversos governos investindo no desenvolvimento de estruturas dedicadas à interoperabilidade. Diversas iniciativas para a criação de padrões estruturados podem ser encontradas por todo o mundo, como o modelo do Reino Unido. Citado por Hopkirk (2008), o e-Government Interoperability Framework (e-GIF), desenvolvido a partir da modernização do governo britânico iniciada em 1999, encorajou a convergência dos sistemas de informação e sua interconexão, maximizando os benefícios para os cidadãos com uma maior coordenação das ações do governo central com os governos locais.

Conforme Murru (2003), a Comissão Europeia, entendendo a importância da interoperabilidade, se comprometeu a desenvolver uma plataforma de interoperabilidade para permitir os serviços eletrônicos em toda a Comunidade Europeia. Para tanto, foi 
estabelecida uma definição geral e definições específicas para compreender a interoperabilidade entre sistemas. A tabela a seguir apresenta estas definições:

Tabela 2: Definições da União Europeia sobre interoperabilidade.

\begin{tabular}{|l|l|}
\hline Titulo & Definição \\
\hline Interoperabilidade & $\begin{array}{l}\text { É a habilidade dos sistemas de tecnologia da informação e comunicação e dos } \\
\text { processos de negócio em suportar a troca de dados permitindo que a informação } \\
\text { e o conhecimento sejam compartilhados. }\end{array}$ \\
\hline $\begin{array}{l}\text { Interoperabilidade } \\
\text { semântica }\end{array}$ & $\begin{array}{l}\text { Garante o significado preciso da informação trocada de forma inequívoca em } \\
\text { todas as aplicações envolvidas em uma determinada operação, permitindo que } \\
\text { os sistemas sejam capazes de tratar informações e processá-las corretamente. }\end{array}$ \\
\hline $\begin{array}{l}\text { Interoperabilidade } \\
\text { organizacional }\end{array}$ & $\begin{array}{l}\text { Trata da definição de objetivos de negócio, modelagem de processos e da } \\
\text { colaboração entre os governos que desejem trocar informações, garantindo que } \\
\text { estruturas organizacionais distintas possam tratar os processos adequadamente. }\end{array}$ \\
\hline $\begin{array}{l}\text { Interoperabilidade } \\
\text { técnica }\end{array}$ & $\begin{array}{l}\text { Trata de garantir que os problemas técnicos (hardware, software, } \\
\text { telecomunicações) envolvidos na interligação de sistemas informáticos e } \\
\text { serviços não afetem o resultado esperado. }\end{array}$ \\
\hline $\begin{array}{l}\text { Governança } \\
\text { interoperabilidade }\end{array}$ & $\begin{array}{l}\text { Trata dos acordos e definições necessários para que a interoperabilidade seja } \\
\text { bem sucedida. }\end{array}$ \\
\hline
\end{tabular}

Fonte: Adaptado de Escobar, 2007

Em 2007 o escritório regional de Bangkok, do Programa das Nações Unidas para o Desenvolvimento, elaborou três publicações sobre interoperabilidade, ressaltando o que passou a ser comumente chamado de GIF - Government Interoperability Framework, que pode ser traduzido como arquitetura de interoperabilidade governamental. Foram reunidas lideranças de 14 países, além da união europeia e especialistas americanos, para debaterem o tema, tendo o Dr. Emmanuel C. Lallana como coordenador dos trabalhos. Durante os trabalhos foram identificados sete países que já possuíam padrões de interoperabilidade governamental.

A tabela a seguir apresenta o país e o correspondente padrão: 
Tabela 3: Frameworks de Interoperabilidade

\begin{tabular}{|l|l|}
\hline \multicolumn{1}{|c|}{ País } & \multicolumn{1}{c|}{ Padrão } \\
\hline Alemanha & Standards and Anchitecture for e-Government Appliations (SAGA) \\
\hline Austrália & Australian Government Technical Interoperability Framework (AGTIF) \\
\hline Brasil & Padrões de Interoperabilidade de Governo Eletrônico (e-Ping) \\
\hline Dinamarca & Danish e-Government Interoperability Framework (DIF) \\
\hline Malásia & Malaysian Government Interoperability Framework (MyGIF) \\
\hline Nova Zelândia & New Zeland e-Government Interoperability Framework (NZ e-GIF) \\
\hline Reino Unido & United Kingdom e-Government Interoperability Framework (UK e-GIF) \\
\hline União Européia & European Interoperability Framework for Pan-European e-Government Services (EIF) \\
\hline
\end{tabular}

Fonte: adaptado de Lallana, 2007

$\mathrm{Na}$ análise destes padrões foram identificados sete aspectos técnicos importantes que devem estar presentes em uma estrutura de interoperabilidade:

1) Interconexão: padrões e tecnologias necessárias para permitir a conexão dos sistemas e a comunicação entre eles. Alguns exemplos: HTTP, FTP, WSDL e SOAP;

2) Integração de dados: padrões relacionados com a troca e processamento de dados, permitindo que os sistemas reconheçam os dados trocados. O principal exemplo e mais amplamente utilizado é o XML;

3) Metadados: elementos e definições para as estruturas de dados, permitindo o entendimento das informações pelos diversos sistemas. Um padrão é o Dublin Core;

4) Acesso à informação e apresentação: trata dos padrões relacionados ao meio de acesso dos cidadãos aos serviços, bem como a forma como estes são a eles apresentados. Alguns padrões são o PDF, JPEG, ODT, entre outros;

5) Padrões para áreas de negócio: define informações específicas para determinadas áreas de negócio, como finanças, saúde e educação; 
6) Webservices: indica a utilização de serviços padronizados na Internet;

7) Segurança: define os padrões que os sistemas devem atender para garantir a segurança da informação, em todos os aspectos, tais como controle de acesso, transmissão segura dos dados, armazenamento e garantia de disponibilidade.

Assim, verificou-se entre os padrões identificados quais aspectos eram atendidos. O resultado está apresentado na tabela abaixo:

Tabela 4 Aspectos da interoperabilidade atendidos em 6 países.

\begin{tabular}{|l|c|c|c|c|c|c|c|}
\hline \multicolumn{1}{|c|}{ País } & Interconexão & Integração & Metadados & AIA & PPAN & Webservices & Segurança \\
\hline Austrália & $\mathbf{X}$ & $\mathbf{X}$ & $\mathbf{X}$ & $\mathbf{X}$ & & & $\mathbf{X}$ \\
\hline Brasil & $\mathbf{X}$ & $\mathbf{X}$ & $\mathbf{X}$ & $\mathbf{X}$ & & & $\mathbf{X}$ \\
\hline Dinamarca & $\mathbf{X}$ & $\mathbf{X}$ & $\mathbf{X}$ & $\mathbf{X}$ & $\mathbf{X}$ & $\mathbf{X}$ & $\mathbf{X}$ \\
\hline Malásia & $\mathbf{X}$ & $\mathbf{X}$ & $\mathbf{X}$ & $\mathbf{X}$ & & & $\mathbf{X}$ \\
\hline Nova Zelândia & $\mathbf{X}$ & $\mathbf{X}$ & $\mathbf{X}$ & $\mathbf{X}$ & $\mathbf{X}$ & $\mathbf{X}$ & $\mathbf{X}$ \\
\hline Reino Unido & $\mathbf{X}$ & $\mathbf{X}$ & $\mathbf{X}$ & $\mathbf{X}$ & & & $\mathbf{X}$ \\
\hline
\end{tabular}

Fonte: Adaptado de Lallana, 2007

De acordo com Qian (2010), os países líderes em governo conectado e transacional são aqueles que integram as operações, transferindo informações de forma eficiente entre seus órgãos e departamentos, provendo melhores serviços on-line. Destacam-se neste grupo a Austrália, Bélgica, Áustria, Canadá, França, Reino Unido, Coréia do Sul e Estados Unidos. Nos países onde o governo eletrônico se encontra em estágio mais avançado, observou-se que a confiança da população no governo é maior que em outros países.

Em 2011 um novo estudo foi empreendido, que identificou GIFs em 30 países: África do Sul, Alemanha, Arábia Saudita, Austrália, Áustria, Bélgica, Brasil, Bulgária, Canadá, China (Hong Kong), Dinamarca, Egito, Espanha, Estados Unidos, Estônia, Etiópia, França, Filipinas, Grécia, Holanda, Hungria, Índia, Malásia, Malta, Mauritânia, Nova Zelândia, Noruega, Polônia, Reino Unido e União Europeia (CS TRANSFORM, 2011).

Das arquiteturas levantadas apenas 17 foram analisadas, tomando como critério o fato de terem sido atualizadas ou criadas após 2007. Nestas, foram encontradas três falhas estruturais comuns: excesso de detalhes nas definições, gerando "amarrações" no desenvolvimento de novas funcionalidades; o foco nos processos internos, faltando visão 
sobre a facilitação do acesso dos cidadãos ao governo; e, por fim, apesar de bem detalhada, a interoperabilidade ainda é incipiente entre os sistemas dos países analisados, mostrando distanciamento entre desejo e realização.

\subsubsection{Interoperabilidade no Brasil}

No Brasil, a importância da integração de sistemas de governo é uma prioridade desde 2001, como constatam Taragino et al. (2005), que apresentaram a preocupação do Comitê Executivo do Governo Eletrônico do Brasil, que tinha entre as principais diretrizes a cooperação, convergência e a própria integração de sistemas de informação, sendo estas questões de fundamental importância para o compartilhamento de informação entre os diversos órgãos.

De acordo com Silva et al. (2009), no Brasil, o governo eletrônico seguiu uma série de diretrizes e determinações com o objetivo de trazer o governo ao alcance do cidadão, pelo acesso à informação. No caso da interoperabilidade de sistemas governamentais, essas diretrizes estão descritas no e-PING, que define um conjunto mínimo de premissas, políticas e especificações técnicas que regulamentam a utilização da Tecnologia da Informação e Comunicação (TIC) na interoperabilidade de serviços de governo eletrônico, ou seja, é o GIF nacional. Uma das prioridades deste programa é a promoção da cidadania através da inclusão digital, visando ampliar a base de cidadãos que podem se beneficiar do aprimoramento tecnológico dos governos. Ao se utilizar essas tecnologias para atender às necessidades de governo, criam-se novas estratégias que possibilitam modernizar a máquina administrativa e disponibilizar um novo canal para atender as necessidades do cidadão.

Santos (2008) descreveu com detalhes o desenvolvimento da arquitetura de interoperabilidade no Brasil, cuja primeira versão foi publicada em 2003. Iniciou com a apresentação de um documento base da arquitetura que define um conjunto mínimo de premissas, políticas e especificações técnicas, regulamentando a utilização de tecnologias na interoperabilidade de serviços de governo eletrônico e estabelecendo as condições para interagir com demais poderes e esferas de governo. Segundo Santos (2008), o modelo nacional foi inspirado pelo modelo britânico que, na época, era um dos mais avançados. 
No documento de referência do e-PING (COMITÊ EXECUTIVO DE GOVERNO ELETRÔNICO, 2012) são apresentadas as especificações técnicas que abordam a interconexão dos sistemas, segurança, meios de acesso, organização e intercâmbio de informações e as áreas de integração do governo eletrônico. No mesmo documento, consta que o e-PING pretende abranger todo o intercâmbio de informações entre os sistemas do governo federal e a interação com os cidadãos, outros níveis de governo, poder legislativo, judiciário e Ministério Público Federal, bem como organismos internacionais, governos de outros países, empresas e o terceiro setor.

Desde a concepção inicial do modelo, o mesmo foi dividido em cinco grupos de atuação especializados, para a melhor estruturação dos trabalhos, que são:

1) Interconexão: estabelece as condições para que os órgãos de governo se interconectem, sendo estabelecidas as especificações para mensageria (correio eletrônico), infraestrutura de rede e serviços de rede;

2) Segurança: trata dos aspectos de segurança de TIC, abrangendo a segurança do protocolo de comunicação IP (internet protocol), do correio eletrônico, da criptografia, do desenvolvimento de sistemas, dos serviços de rede, das redes sem fio, além da coleta, do tratamento e do arquivamento de evidências;

3) Meios de acesso: são explicitadas as questões relativas aos padrões dos dispositivos de acesso aos serviços de governo eletrônico, tais como: especificações de estações de trabalhos, cartões inteligentes, dispositivos de armazenamento de senhas e mobilidade. No caso de estações de trabalhos (computadores pessoais e notebooks) são tratados os padrões de navegadores de internet (browsers), conjunto de caracteres e alfabetos, formato de intercâmbio de hipertexto, formato de arquivos dos tipos documento, planilha de cálculo, apresentação de trabalhos, banco de dados pessoais, intercâmbio de informações gráficas e imagens, gráficos vetoriais, animação, áudio e vídeo e compactação de arquivos. Para os cartões inteligentes e similares são definidos a estrutura de dados, aplicações, protocolos de comunicação, interface física e segurança. No caso de mobilidade é tratado o protocolo de transmissão, navegador, programação, mensageria e formatos de arquivos; 
4) Organização e intercâmbio de informações: aborda os aspectos relativos ao tratamento e à transferência de informações nos serviços de governo eletrônico. Inclui padrão de estrutura de assuntos de governo e de metadados, compreendendo a linguagem para intercâmbio e transformação de dados, lista de assuntos do governo e sua taxonomia e padrão de metadados;

5) Área de integração para governo eletrônico: estabelece a utilização ou construção de especificações técnicas, baseadas no padrão XML, para sustentar o intercâmbio de informações em áreas transversais da atuação governamental, definindo um catálogo padrão de dados, catálogo de esquemas de XML e catálogo de serviços interoperáveis. (E-Ping, Padrões de Interoperabilidade de Governo Eletrônico, 2012).

Uma nova versão da arquitetura foi lançada em 2004 e a cada dois anos ela é atualizada, sendo a mais atual a de agosto de 2012. Além da e-PING o governo também trabalha a eMAG, padrões para acessibilidade, a e-PWG, que apresenta padrões para o governo na Internet e indicadores e metas para avaliação de serviços eletrônicos, entre outros.

Dentro da arquitetura de interoperabilidade também estão definidos o e-VOG, vocabulários e ontologias do governo eletrônico e o e-PMG, padrão de metadados do governo eletrônico, essenciais para que haja um bom compartilhamento de dados, além de facilitar o desenvolvimento de conectores entre os sistemas governamentais.

Desde 2005 todos os sistemas desenvolvidos pelo executivo federal, por meio da portaria SLTI/MP $n^{\circ} 5$, devem seguir a e-PING, porém tal obrigatoriedade não atinge os sistemas legados, nem outros poderes ou outras instâncias, como os poderes estaduais e municipais. Assim, se a interoperabilidade é uma realidade para os novos sistemas federais, oferece pouco ganho efetivo para o cidadão, pois os principais sistemas das áreas fins, como os da previdência, saúde e educação, ainda carecem de interoperabilidade efetiva. Na contramão desta tendência temos a evolução da tecnologia bancária brasileira, que desde o século passado trabalha com interoperação de sistemas, culminando com o desenvolvimento do SPB, Sistema de Pagamentos Bancários, e o DDA, Débito Direto Autorizado, que trabalham com o conceito de camadas de integração, interligando sistemas das mais diversas instituições bancárias. 
É interessante notar que a despeito da e-PING os desenvolvimentos dos padrões de trocas de informações bancárias também seguiram padrões, já bem estabelecidos mundialmente (DA FONSECA, MEIRELLES e DINIZ, 2010).

\subsection{Processos Intergovernamentais}

A organização de cada estado nacional é uma evolução de sua formação sociopolítica. O Brasil começou como uma monarquia e passou a república, se organizando como uma federação a exemplo dos Estados Unidos da América. No entanto, a constituição de 1988 alterou a organização federativa de forma significativa ao criar a União e incluir os municípios, tornando-os entes federados e possibilitando suas autonomias políticoadministrativas (RIBEIRO, 2009), tornando a ação governamental mais local quanto possível. Cada país possui características próprias de organização e independência entre seus entes. Como exemplos, podemos citar Portugal, cuja divisão é por distritos, mas há duas regiões autônomas com governos próprios, as de Açores e Madeira. Já na organização americana, cada estado possui grande independência, porém os municípios não são entes federados, mas organizações territoriais dentro de cada estado. De outra forma, o modelo se reproduz quando se trata de organizações como a União Européia e o Mercosul, onde informações de diversos tipos devem ser trocadas entre os estados participantes. Dessa forma, apesar de estruturalmente diferente, relações intergovernamentais são muito presentes na sociedade moderna.

Quanto à estrutura existente no Brasil, a reforma redesenhou os padrões de prestação de serviços e definiu uma nova distribuição de função para cada nível governamental. No entanto, a constituição não especifica claramente a definição de funções, delegando a execução para uma cooperação entre municípios, estados e União, dando forma a uma estrutura cooperativa nas relações intergovernamentais (Abrucio \& Franzese, 2008).

Almeida (2007) ressalta que as novas regras trouxeram desafios para todos os níveis de governo, tanto no que diz respeito ao desenho de políticas, quanto como lidar com uma estrutura federativa do tipo cooperativo em que as responsabilidades na provisão de serviços básicos devem ser compartilhadas. Em várias competências previstas pela Constituição há repartição de funções, estando ao mesmo tempo os três níveis responsáveis por executá-las. Esse modelo federativo pode levar, muitas vezes, à 
execução de políticas públicas sem nenhuma integração, descoordenadas entre si. Essa estrutura pressupõe troca de informações, mas não há sistemas informatizados únicos centralizados e sim vários sistemas localizados. Abrucio (2008) argumenta que os processos de centralização ocorridos mais recentemente, tiveram na coordenação de políticas públicas um elemento-chave.

Segundo Souza (2010), atribuir encargos com exclusividade para cada ente federado seria a forma mais eficiente de organizar a prestação de serviços públicos, quando distribuída entre diversas jurisdições dotadas de autonomia. Com isso se evitaria as dificuldades associadas à atuação conjunta de vários governos e tornar-se-ia mais transparente para o cidadão quem responde por cada serviço. No entanto, a atribuição exclusiva de encargos pode gerar ineficiência por questões de escala, onde o serviço seria prejudicado se exercido apenas localmente. Se por um lado a descentralização é desejada, a ineficiência no serviço público que pode surgir não o é.

Oates (1999) considera adequado a atribuição de competências ao nível de governo mais próximo do cidadão - buscando as vantagens da descentralização - desde que as funções possam ser executadas com eficiência. Com isso se pressupõe que haveria tarefas a serem atribuídas ao governo local, outras aos estados e outras à União, originando um raciocínio que não prevê ações conjuntas ou compartilhadas, mas cujo compartilhamento de informações poderia tornar o processo mais eficiente.

Seguindo este raciocínio, Rezende (2006) conclui que "no âmbito da educação, faz sentido que o ensino fundamental seja atribuição local e o ensino universitário seja estadual. Da mesma forma, atendimento básico de saúde deve ser municipal, mas os hospitais têm dimensão adequada à esfera estadual ou federal”.

No entanto, algumas ações, como gerenciamento de hospitais, construções de rodovias, tratamento de lixo ou outras situações ambientais, pressupõem ação conjunta entre municípios, por questões de escala ou escopo, que pode ser através de consórcios, ou através da coordenação das ações pelos estados ou a União. No entanto, a eficiência das ações é inversamente proporcional ao número de entes envolvidos, pois em grupos maiores há dificuldades de coordenação e maior possibilidade de surgimento de ineficiências oriundas de comportamentos individualistas (REZENDE, 2006).

No Brasil, muitas vezes as competências são concorrentes. Assim, não apenas a cooperação é necessária, mas também uma forma de trocar informações que permita o 
acompanhamento simultâneo das ações dos diferentes entes, de forma a gerar coordenação e planejamento unificados. Há a necessidade de compreender a federação como algo maior do que simplesmente os seus integrantes. Dessa forma, a colaboração deve ser consolidada através de mecanismos de governança da interoperabilidade. A governança da interoperabilidade é utilizada para identificar os principais âmbitos a considerar nos acordos entre Governos que participam dos processos de interoperabilidade, incluindo os espaços de diálogo onde os ditos acordos são definidos, bem como os mecanismos de colaboração institucional para levá-los a cabo. Em suma, o propósito da governança da interoperabilidade é o de identificar e remover as barreiras potenciais, inclusive políticas, legislativas, gerenciais, econômicas, culturais e outras para acrescentar os serviços públicos e compartilhar informações entre diferentes entes governamentais. (CRIADO, GASCOU e JIMÉNEZ, 2010). Dessa forma, gera-se a necessidade de compreensão do governo eletrônico dentro do contexto da integração intergovernamental.

\subsection{Integração de sistemas para a cooperação governamental}

Para Fugini, Maggiolini e Pagamici (2005), as cidades ou o Estado são coletividades territoriais em que a estrutura burocrática da prefeitura ou do Estado é somente uma parte de um sistema muito mais amplo, no qual devem ser considerados, com uma visão unitária e integrada, os órgãos políticos elegíveis, a comunidade administrada e o inteiro território de competência. Desta forma, Fugini, Maggiolini e Pagamici (2005) entendem que o verdadeiro governo eletrônico é aquele em que os sistemas de informação também estejam integrados. Para que isso seja possível, é necessário que as estruturas e a sociedade, como responsáveis cada uma por uma parte da informação, se disponham a fornecer sua parte de conhecimento em um processo de colaboração e troca.

Para Riempp, Müller e Ahlemann (2008), a evolução nos serviços públicos ocorre à medida que as informações oriundas das várias esferas de governo, entidades e órgãos possam ser integradas de forma efetiva. Neste aspecto, o governo poderia ter como exemplo a iniciativa privada. As fronteiras organizacionais estão se dissolvendo para alcançar uma reação mais rápida às necessidades do consumidor e isso deveria valer também para o consumidor do governo, o cidadão. 
De acordo com Pacheco e Kern (2003), a baixa qualidade da informação e a falta de integração são problemas comuns em projetos de sistemas de informação governamentais. Os autores complementam que, vencendo esses problemas, é possível progredir muito rapidamente, com benefícios palpáveis para a sociedade, pois a oferta de informação gera sua própria demanda.

Na mesma linha, Luna (2007) apresenta a importância da integração horizontal no Governo, através de ações integradas, articulação governamental e integração de serviços. O autor apresenta a visão de governo canadense reproduzindo as palavras do coordenador de Gestão de Iniciativas Horizontais, James Lahey:

\footnotetext{
"Há algum tempo, os gerentes do serviço público reconheceram que trabalhar sem restrições impostas por fronteiras entre órgãos do governo é pré-requisito essencial para muitas de suas atividades (...). A necessidade da gestão horizontal tem se tornado mais premente em número crescente de casos, para que tarefas essenciais possam ser cumpridas. Sem este tipo de colaboração, torna-se muito difícil administrar questões transversais relacionadas a políticas ou prestar serviços aos cidadãos de maneira que façam sentido para eles.” (LUNA, 2007)
}

Luna cita ainda o exemplo da Inglaterra que declara a questão da integração como parte do programa de modernização do governo.

De acordo com Knight, Fernandes e Cunha (2007), os sistemas informatizados relevantes para a prestação de serviços prioritários ao cidadão e para a gestão de políticas públicas, bem como os de apoio à gestão, devem estar alinhados a uma estratégia de integração que proporcione o progressivo compartilhamento de dados e interligação dos fluxos de processos. A integração possibilita a obtenção de avanços palpáveis na prestação de serviços ao cidadão e na melhoria do processo decisório. Eles citam a iniciativa do governo canadense denominada GOL (Government On-Line, 2007), que tem como objetivo tornar o governo mais acessível e com melhores serviços, garantindo ainda a segurança e privacidade dos serviços on-line. Embora os autores mencionem que houve grande evolução por meio desta iniciativa, existe a necessidade de melhoria contínua e, para continuar avançando, uma das medidas é o fomento à interoperabilidade e integração nos níveis de negócios, informação e técnico. Também citam o caso do Chile que, embora tenha desenvolvido o governo eletrônico, ainda possui vários desafios a enfrentar, sendo um deles a integração dos serviços eletrônicos prestados, permitindo pontos de contato únicos, orientados ao processo e construindo uma forte colaboração recíproca entre eles. 
Outro desafio é a construção de uma integração vertical entre governo central, regional e local com foco nos serviços aos cidadãos. No caso de Sri Lanka, o governo criou uma Agência de Tecnologia da Informação e Comunicação (ATIC) que, dentro de sua política de tecnologia da informação e comunicação, previu uma reengenharia do governo, tendo como um dos pilares o compartilhamento eletrônico de bases de dados entre as agências governamentais, interconectando essas agências para atingir um nível maior de produtividade.

Para Santos (2002), o nível de excelência é alcançado quando todos os órgãos estão integrados por meios eletrônicos nas diferentes esferas e poderes da administração pública, estando o foco, deste modo, totalmente no cidadão. De acordo com Campos e Marques (2006), é necessária uma grande coordenação para gerir a partilha de informação entre organismos dispersos, mas necessariamente inter-relacionados, que exigem uma reorganização.

Dando sequência aos trabalhos de governo eletrônico desenvolvidos de 2000 a 2002, em 2003 o governo federal iniciou uma série de encontros e discussões para estabelecer um modelo de interoperabilidade de sistemas para o Brasil, que foi denominado e-PING.

A primeira versão do modelo surgiu em 2004, quando a interoperabilidade no sistema financeiro nacional já era uma realidade e um sucesso, através do Sistema de Pagamentos Brasileiro (SPB), que interliga as operações bancárias no país, sendo esta a primeira aplicação pública de grande monta a utilizar a interoperabilidade com uma camada de integração (SERPRO, 2004).

Com o governo reconhecendo e apoiando a interoperabilidade como uma solução de integração, os técnicos estaduais começaram a apresentar outras possibilidades de uso, para além das questões financeiras e tributárias ${ }^{1}$. Áreas fim de governo, como educação, saúde e segurança, poderiam se beneficiar positivamente das integrações possíveis com o modelo de interoperabilidade, permitindo a troca de informações entre sistemas cuja integração, antes, seria impensada, fosse pela complexidade dos mesmos ou por

\footnotetext{
${ }^{1}$ Um exemplo são as propostas para a Política Nacional de Informação e Informática em Saúde da $12^{\text {a }}$ Conferência Nacional de Saúde no DATASUS sobre utilização da interoperabilidade na integração de sistemas de saúde, realizada em 29 de março de 2004, acessível em: http://www2.datasus.gov.br/DATASUS/index.php?area=0501
} 
pertencerem a diferentes esferas e níveis de poder independentes (ALBUQUERQUE FILHO e PESSI, 2010).

Permitir a troca de informações sem interferir na independência dos sistemas é hoje um dos destaques das redes sociais, que usam webservices para gerar interoperabilidade entre seus sistemas. Assim como Facebook, Twitter, Google, etc. se beneficiam com trocas de dados e publicação de informações cruzadas, além de portais de diversos meios de comunicação (como UOL ${ }^{2}$ e Jornal Estado de São Paulo ${ }^{3}$ ), os governos também podem utilizar esses mecanismos para melhorar a forma como prestam serviços aos seus cidadãos.

Seguindo o mesmo raciocínio, os serviços de governo eletrônico podem ser oferecidos em diversas plataformas além da Internet, como celulares ou TV Digital. Esta forma de dispor conteúdo é conhecida como crossmedia, sendo que MIYAMARU e FILGUEIRAS descreveram a importância da interoperabilidade no processo:

Serviços de Governo normalmente interligam diferentes níveis e departamentos. Na maioria das vezes cada instância de governo possui sua própria plataforma tecnológica. Para entregar serviços entre meios um padrão de interoperabilidade precisa ser definido. O Governo Brasileiro uma iniciativa para padronizar as operações entre serviços on line, que pode ser estendida para diferentes meios. (MIYAMARU e FILGUEIRAS, 2009).

Mas, ao mesmo tempo em que a interoperabilidade passou a ser discutida com propriedade pelo Governo Federal, questões conjunturais levaram ao lento desenvolvimento do modelo. Segundo Pinto e Fernandes (PINTO e FERNANDES apud DINIZ, BARBOSA, et al., 2009): "[...] apesar do sucesso na institucionalização do

${ }^{2}$ UOL (acrônimo de Universo On Line) é um portal de conteúdo e compras na Internet. Surgiu inicialmente com apenas conteúdo próprio, porém evoluiu, agregando hoje conteúdo variado, oriundo de parcerias diversas. Muitos sites que antes eram independentes, como o Contas Abertas (site de transparência pública que apresenta os dados de execução orçamentária do governo federal de forma simplificada, facilitando a consulta e análise, usado principalmente por jornalistas) passaram a pertencer ao portal, que pode ser acessado em www.uol.com.br.

${ }^{3}$ Principal jornal de grande circulação do Estado de São Paulo, que realizou modificações na forma de apresentar o jornal impresso para aproximá-lo da linguagem da Internet, oferecendo o conteúdo on-line em www.estadao.com.br. 
Programa de Governo Eletrônico, ele vem perdendo a prioridade governamental desde a transição de governo ocorrida em 2003." (PINTO e FERNANDES, 2005).

Segundo os autores, foram quatro os fatores principais para a morosidade: mudança da liderança política, com os indicados do governo não desempenhando o mesmo papel que teve o anterior chefe da Casa Civil; falta de coordenação intraburocrática, com a diluição de representantes nos ministérios; dificuldade de articulação com a sociedade, devido às incertezas geradas pelos modelos adotados pelo governo e às restrições legais existentes; e a falta de recursos para projetos do setor.

Com a evolução, tanto da legislação sobre transparência como da tecnologia, ficou evidente o atraso na gerência das informações governamentais. Cunha et al resumiram muito bem a questão: “As empresas privadas têm investido muito em soluções para os problemas de interoperabilidade nos últimos anos. E o setor público está em posição desfavorável com sua forma arcaica de gerenciar problemas e criar soluções.” (2005)

Ao mesmo tempo, os órgãos de controle estaduais, em especial os órgãos de segurança, começaram a perceber as vantagens e possibilidades de trocas de informações entre sistemas, para garantir transparência e controle dos convênios e ações do Estado. Conforme Souza:

Fica então evidenciado que um dos maiores problemas da gestão da segurança pública brasileira (...) é a falta de ações integradas, colaborativas e de efetivo compartilhamento de informações (SOUZA, 2003).

Segundo o $\mathrm{W} \mathrm{C}^{4}$ a demanda por interoperabilidade entre sistemas cresce na Internet, seguindo a mesma evolução dos dispositivos acoplados à rede que necessitam de interoperabilidade entre si (W3C BRASIL, 2011).

Assim, tem-se o aumento do uso de interoperabilidade entre sistemas privados e o uso intensivo das redes sociais como mecanismos de cidadania, mostrando clara tendência de que o mesmo ocorrerá nos sistemas governamentais.

${ }^{4}$ W3C é um acrônimo para World Wide Web Consortion, o consórcio mundial que regula padrões para a Internet. 


\subsection{Eficiência na interoperabilidade intergovernamental}

A constituição da República Federativa do Brasil de 1988, em seu artigo 37 dispõe que "a administração pública direta ou indireta de qualquer dos Poderes da União, dos Estados, do Distrito Federal e dos Municípios obedecerá ao princípio de legalidade, impessoalidade, moralidade, publicidade e eficiência". O conceito de eficiência em administração pública é confundido com o de eficácia, conceitos complementares em administração.(BATISTA JUNIOR, 2004).

O Tribunal de Contas da União orienta que eficiência "é a relação entre os produtos (bens e serviços) gerados por uma atividade e os custos dos insumos empregados em um determinado período de tempo". (BRASIL, 2000)

Segundo o Exército Brasileiro, "a eficiência mensura a produtividade, assim, é a medida entre os recursos utilizados em comparação aos resultados dos processos". (PROGRAMA EXCELÊNCIA GERENCIAL, 2004)

Nesse sentido, Garcia (2008) define eficiência no âmbito da ciência da administração:

\footnotetext{
"a eficiência diz respeito à maneira de utilização dos recursos, ou ainda significa fazer as coisas de forma correta, solucionar problemas, cumprir com seu dever, diminuir custos. Portanto, a eficiência está relacionada ao fazer corretamente as coisas, otimizando os recursos disponíveis."
}

Foi visto que com o uso da interoperabilidade é possível melhorar a eficiência na execução de serviços públicos compartilhados, pois com a cooperação gerada pela interoperabilidade dos sistemas intergovernamentais gera-se compartilhamento de dados e equipamentos e consequentemente tem-se diminuição de custos de escala. No entanto, para que a interoperabilidade ocorra os entes participantes devem abdicar de suas individualidades, permitindo a geração de padrões que não apenas viabilizem, mas facilitem as trocas de dados entre os sistemas. No Brasil a melhor forma de viabilizar as trocas de dados é utilizar a e-PING (COMITÊ EXECUTIVO DE GOVERNO ELETRÔNICO, 2008) e modelos decorrentes desta arquitetura nacional de interoperabilidade. Assim, a eficiência gerada pela interoperabilidade entre sistemas pode ocorrer na melhoria de produtividade (com redução de custos ou tempos para a execução das trocas de dados) ou na reformulação administrativa ou de processos. São estas as 
principais questões a serem analisadas para verificar se o uso da interoperabilidade impactou na eficiência dos processos intergovernamentais de governo eletrônico.

\subsubsection{Dificuldades para adoção da interoperabilidade}

Se a interoperabilidade entre sistemas governamentais é positiva tanto para governos quanto para cidadãos, porque sua implantação não ocorre naturalmente? Arcieri et al (2002) afirmam que são de origem organizacional, e não técnica, os problemas difíceis de serem superados. Nesse sentido, citam que "um dos objetivos mais difíceis de alcançar no desenvolvimento de sistemas de informação cooperativos é a coerência dos conjuntos de dados, geralmente distribuídos" (ARCIERI ET AL, 2002). Cada organização deseja gerenciar seus dados de forma independente, porém para a troca coerente de informações as taxonomias devem ser intercambiáveis, ou seja, os dados devem ser interpretados da mesma forma pelos diferentes sistemas, o que exige a padronização destes. Um exemplo é o CEP, padrão necessário para a localização de endereços que se não for utilizado corretamente impede a localização do destinatário ou do remetente da correspondência. Uma solução seriam bases de dados públicas que fossem utilizadas pelos diversos sistemas, porém cada organização deseja possuir a própria base de dados. Assim, o governo gera incongruências como múltiplos cadastros dos cidadãos e de empresas, dificultando a localização das informações. A dificuldade de cruzar dados com nomenclaturas diversas foi um dos problemas encontrados pela corregedoria do Estado de São Paulo quando da constatação da necessidade de um padrão (ALBUQUERQUE FILHO e PESSI, 2010).

Santos L. (2002) considera que são pressupostos fundamentais para a adoção da interoperabilidade a resolução política dos conflitos, estabelecendo estruturas padronizadas, unificadas e controladas, bem como bancos de dados que se interrelacionem e conversem entre si. As ilhas de informação deveriam ser dissolvidas de forma a conciliar interesses, unificando bancos de dados e protocolos e estabelecendo mecanismos que conectem as redes, mesmo mantendo-as separadas, diminuindo retrabalho de funcionários públicos, melhorando o fluxo das informações e a reprodução da informação a ser fornecida pelo cidadão. As próprias redes já estabelecidas pelos governos locais podem ser aproveitadas para estas ações, mas são dependentes da articulação governamental. 
Para Vassilakis e Lepouras (2006), os serviços eletrônicos são inevitáveis e estão sendo criados, mas a evolução deles depende de uma série de fatores, tais como:

1) Combinação da prestação de serviços em determinado momento da vida do cidadão ou da empresa;

2) Catalogação de serviços com múltiplas taxonomias, para que possam ser localizados mais facilmente;

3) Modelagem dos sistemas de forma a permitir adaptação mais rápida às mudanças de legislação ou processos, visando desburocratizar serviços;

4) Definir, para serviços que são dependentes de múltiplos órgãos públicos, responsáveis administrativos em cada etapa que garantam a manutenção de padrões.

Segundo os autores:

\footnotetext{
"esses fatores podem ser solucionados com a representação semântica dos vários aspectos dos serviços eletrônicos, conceitos, relacionamentos e com o uso de ontologias definindo as responsabilidades, metadados, documentos e legislação, permitindo, desta forma, a interoperabilidade" (VASSILAKIS e LEPOURAS, 2006).
}

De acordo com Diniz (2005), a eficiência do uso de diversos canais de comunicação com o cidadão exige a construção de uma plataforma comum de integração dos serviços e aplicações.

A plataforma de interoperabilidade é definida por Barros, Cepik e Canabarro (2010) correspondendo aos componentes tecnológicos necessários para que ocorra o intercâmbio de dados entre provedores e consumidores de informação. Estas plataformas, que buscam a padronização de um ambiente comum de troca de informação e de entrega de serviços, independente dos sistemas que processam as informações, são vitais para tornar viáveis as iniciativas de governo eletrônico.

Wauters (2010) corrobora a opinião de Diniz quando afirma que a "interoperabilidade é um facilitador essencial para o futuro dos serviços de governo eletrônico".

Pardo e Burke (2008) identificaram que a interoperabilidade no governo, para que possa ser efetiva, precisa ser abordada por diversas dimensões, apresentadas na tabela abaixo: 
Tabela 5: Dimensões da Interoperabilidade.

\begin{tabular}{|c|c|}
\hline Dimensão & Descrição \\
\hline GOVERNANÇA & $\begin{array}{l}\text { A existência de regras e procedimentos adequados para direcionar e } \\
\text { supervisionar as iniciativas de interoperabilidade do governo e para garantir } \\
\text { que os investimentos em interoperabilidade dos governos estejam alinhados } \\
\text { com as prioridades e metas definidas no planejamento estratégico. }\end{array}$ \\
\hline $\begin{array}{l}\text { PLANEJAMENTO } \\
\text { ESTRATÉGICO }\end{array}$ & $\begin{array}{l}\text { O planejamento estratégico deve ser bem preparado e prever todos os recursos } \\
\text { e integração com outros elementos de gestão. }\end{array}$ \\
\hline $\begin{array}{l}\text { DESENVOLVER } \\
\text { CASOS DE SUCESSO }\end{array}$ & $\begin{array}{l}\text { É necessário existir casos de sucesso e pilotos para convencer os principais } \\
\text { patrocinadores e interessados que a interoperabilidade trará benefícios efetivos, } \\
\text { dentro dos custos estimados. }\end{array}$ \\
\hline $\begin{array}{l}\text { GESTÃO } \\
\text { PROJETOS }\end{array}$ & $\begin{array}{l}\text { É fundamental a gestão estruturada de projetos para garantir o adequado } \\
\text { acompanhamento, controle de prazos e recursos e administração de riscos. }\end{array}$ \\
\hline $\begin{array}{l}\text { IDENTIFICAÇÃO DOS } \\
\text { PRINCIPAIS ATORES }\end{array}$ & $\begin{array}{l}\text { Identificar quem são as pessoas importantes para que elas possam auxiliar na } \\
\text { implementação do projeto e garantir seu envolvimento na motivação e } \\
\text { execução das tarefas. }\end{array}$ \\
\hline $\begin{array}{l}\text { ARQUITETURA } \\
\text { TECNOLÓGICA }\end{array}$ & $\begin{array}{l}\text { O sucesso sob o aspecto técnico é totalmente dependente da correta escolha da } \\
\text { arquitetura tecnológica para que os requisitos de negócio sejam plenamente } \\
\text { atendidos. }\end{array}$ \\
\hline $\begin{array}{l}\text { AVALIAÇÃO } \\
\text { DESEMPENHO }\end{array}$ & $\begin{array}{l}\text { É fundamental o acompanhamento da evolução do projeto para que os } \\
\text { objetivos sejam alcançados e ajustes de curso possam ser feitos a tempo. }\end{array}$ \\
\hline COLABORAÇÃO & $\begin{array}{l}\text { A colaboração dos diversos participantes do projeto deve ser incentivada para o } \\
\text { sucesso do projeto. }\end{array}$ \\
\hline $\begin{array}{l}\text { COMPATIBILIZAÇÃO } \\
\text { DAS ORGANIZAÇÕES }\end{array}$ & $\begin{array}{l}\text { É fundamental que haja uma compatibilização de informações e das estruturas } \\
\text { das organizações para os estilos de trabalho e para que as relações interpessoais } \\
\text { possam ser trabalhadas para melhoria da tomada de decisões e solução de } \\
\text { conflitos }\end{array}$ \\
\hline $\begin{array}{ll}\text { POLÍTICA } & \text { DE } \\
\text { TRATAMENTO } & \text { DA } \\
\text { INFORMAÇÃO } & \end{array}$ & $\begin{array}{l}\text { Devem ser desenvolvidas políticas claras para lidar com coleta, uso, divulgação } \\
\text { e armazenamento de informações, bem como a privacidade, confidencialidade } \\
\text { e segurança }\end{array}$ \\
\hline $\begin{array}{l}\text { GESTÃO } \\
\text { MUDANÇAS }\end{array}$ & $\begin{array}{l}\text { Devem ser planejadas as ações e divulgação de informações visando tratar } \\
\text { possíveis adaptações ou mudanças na dinâmica dos processos, evitando } \\
\text { atitudes negativas e minimizando impactos gerados pelos novos processos. }\end{array}$ \\
\hline $\begin{array}{l}\text { SEGURANÇA } \\
\text { INFORMAÇÃO }\end{array}$ & $\begin{array}{l}\text { Tratamento adequado das formas de coleta, armazenamento, uso e manipulação } \\
\text { de dados, documentação de bases de dados e registros de sistemas, definição de } \\
\text { padrão de qualidade dos dados e dicionários. Garantia de existência de } \\
\text { protocolos de segurança adequados para os dados, aplicações, sistemas e redes. }\end{array}$ \\
\hline $\begin{array}{l}\text { COMPATIBILIDADE } \\
\text { TECNOLÓGICA }\end{array}$ & $\begin{array}{l}\text { A presença de padrões de hardware, software, conectividade para permitir o } \\
\text { compartilhamento de informações. }\end{array}$ \\
\hline
\end{tabular}

Fonte: adaptado de Pardo e Burke, 2008 
No entanto, apesar da existência de diversas diretrizes, informações e modelos para aplicação, a evolução da interoperabilidade em Governo Eletrônico enfrenta dificuldades.

Em 2007, a Secretaria de Logística e Tecnologia da Informação apresentou uma pesquisa realizada sobre o e-PING (SLTI, 2007), que tinha como objetivo verificar a situação da sua utilização. Essa pesquisa foi realizada com gestores e técnicos de tecnologia da informação e comunicação dos órgãos federais.

Quando foram questionados sobre seu conhecimento sobre e-PING, a grande maioria disse possuir apenas conhecimentos gerais e, portanto, não estavam em condições de utilizar o padrão. Na mesma pesquisa, foi questionado se a organização à qual o servidor público estava vinculado utilizava o e-PING. A maioria declarou que não.

Em uma pergunta aberta, solicitou-se que fossem apontadas as dificuldades de utilizar padrões de interoperabilidade. Os principais pontos encontrados foram: a dificuldade de adaptar os sistemas antigos, pouco conhecimento técnico do padrão, falta de uso do ePING nos sistemas estruturantes do governo, deficiência do e-PING em detalhamento do uso de padrões, cultura de desenvolvimento de sistemas isolacionistas e falta de política de disseminação do e-PING.

Quando questionados sobre se a organização a qual pertenciam usava algum padrão de metadados, a maioria informou que não. Além disso, mencionaram que os desenvolvedores de sistemas não estavam preocupados em permitir que seus sistemas tivessem capacidades futuras de interoperar.

Sobre o e-PING, Taragino et al. (2005) citam que, antes do modelo federal, a troca de dados apresentava diversas dificuldades, principalmente a carência semântica sobre os dados. Complementam afirmando que a falta de padronização atual ainda exige uma interpretação humana dos dados, o que dificulta a tarefa de localização de erros e é custoso.

Uma pesquisa semelhante foi realizada no Estado de São Paulo por Garda (2011), com 26 técnicos estaduais de 22 órgãos públicos diferentes, sendo que $96 \%$ destes trabalhavam diretamente na gestão, desenvolvimento ou operação de sistemas de informação.

Na pesquisa, todos os consultados assinalaram que a integração de sistemas no Estado é importante. Ainda conforme a pesquisa, $100 \%$ dos consultados informaram existir a necessidade de integração com outros sistemas internos, sendo que para $85 \%$ essa integração já foi realizada em algum nível. A necessidade de integração com outras 
organizações foi apontada por 92\% e $84 \%$ afirmaram que a integração já existia em algum nível. No entanto, a integração de sistemas foi confundida por alguns respondentes com ações de Business Intelligence. Por fim, foi perguntado se foi seguido algum padrão de troca de informação no processo de integração. Metade falou que sim, mas a maioria não adotou a e-PING. No todo da pesquisa percebe-se a importância da integração dos sistemas no Estado e que não são questões técnicas as limitantes da implantação. A tabela seis resume os motivos apontados para adoção, elencados pela frequência com que apareceram.

Tabela 6: resultados da pesquisa no Estado de São Paulo

\begin{tabular}{|c|l|}
\hline Ranking & \multicolumn{1}{|c|}{ Motivos para adotar } \\
\hline 01 & Evitar duplicidade \\
\hline 02 & Reduz retrabalho de inserção de dados e duplicação de dados \\
\hline 03 & Maior agilidade na recuperação de informações \\
\hline 04 & Coordenar ações de TIC nos órgãos \\
\hline 05 & Maior agilidade e confiabilidade na troca de informações entre sistemas \\
\hline 06 & Permite consistências cruzadas \\
\hline 07 & Melhorar a produtividade \\
\hline 08 & O governo é essencialmente prestador de serviços e o relacionamento com a sociedade deve ser \\
\hline 09 & Informações coletadas e tratadas em um sistema podem ser úteis para outros sistemas \\
\hline 10 & Melhoria da qualidade da informação \\
\hline 11 & Redução de prazos \\
\hline 12 & Maior confiabilidade \\
\hline 13 & Maior agilidade na resposta \\
\hline 14 & Melhor Gestão da Informação \\
\hline 15 & Garantia de execução dos processos \\
\hline 16 & Maior inteligência na tomada de decisões \\
\hline 17 & Para que possa avaliar os resultados de sua gestão e prestar contas ao cidadão \\
\hline
\end{tabular}

Fonte: adaptado de Garda, 2011

No entanto, apesar de tantas motivações para adoção, a interoperabilidade pouco avançou no estado de São Paulo. Sendo assim, a análise dos problemas e dificuldades que levam à não implementação são de essencial compreensão, pois só compreendendo as causas é que o problema pode ser eliminado. 
Santos e Reinhard (2010) analisaram as barreiras para a implantação da interoperabilidade no Brasil. Entre os estudos analisados foram apresentadas as ideias de Anderssen e Dawes e de Scholl e Klischewiski.

Anderseen e Dawes (1991) classificam as barreiras para adoção da interoperabilidade nos governos em quatro naturezas distintas:

Política: falta de definição das diretrizes para as políticas adotadas; conflitos na definição dos níveis de privacidade para acesso às informações; cultura organizacional predominante contrária; ambiguidade do responsável pela coleta e guarda das informações; descontinuidade administrativa.

Organizacional: cultura organizacional; nível das competências dos envolvidos no processo; falta de experiência e ausência de boa vontade dos colaboradores.

Financeira: falta de recursos em outros órgãos para prover informação; a forma como os recursos são adquiridos (normalmente pelo menor preço ao invés do maior valor).

Técnica: Incompatibilidade entre hardware e software; direitos de propriedade não verificados; capacidade insuficiente para geração e armazenamento de dados pelos sistemas; falta de um padrão de metadados.

Já Scholl e Klischewiski (2007) acreditam que são nove as restrições à adoção da interoperabilidade pelos governos:

Legal / Constitucional: a integração e interoperabilidade entre sistemas pode ser considerada inconstitucional ou ilegal, porque o acesso a dados requer poderes que normalmente estão divididos em diversas áreas de governo;

Jurisdicional: nem sempre o governo tem o poder de impor a interoperabilidade entre órgãos ou entidades não governamentais, que não são obrigadas a fornecer as informações. Com isso acordos precisam ser firmados, pois o fornecimento dos dados é voluntário;

Colaborativo: as organizações possuem interesses que as distinguem quanto à interoperabilidade. Experiências passadas, organização sociopolítica e estilo de liderança influenciam na disposição de interoperar;

Organizacional: processos e recursos são diferentes entre as organizações, que precisam alinhar seus processos e padrões para poderem usufruir da interoperabilidade entre os sistemas; 
Informacional: enquanto informações transacionais podem ser mais facilmente compartilhadas, informações estratégicas ou organizacionais não o são. Se faz necessário o estabelecimento de padrões de controle e qualidade na análise e compartilhamento de informações;

Gerencial: a complexidade da interoperabilidade aumenta quando interesses difusos ou necessidades estão envolvidos. Dessa forma, as demandas gerenciais extrapolam a capacidade de interoperação dos parceiros. No entanto, se os interesses forem controlados, a interoperabilidade pode acontecer;

Custo: A extrapolação dos custos de um projeto de interoperabilidade pode ultrapassar a capacidade de financiamento dos parceiros envolvidos. Para evitar este tipo de problema é necessário um levantamento realista das necessidades de recursos para a execução plena do projeto, pois nada adianta se for implementado pela metade;

Tecnologia: a heterogeneidade das plataformas de governo eletrônico e as capacidades das redes podem restringir o processo de interoperabilidade. No entanto, as constantes evoluções tecnológicas podem rapidamente eliminar estas restrições;

Performance: Quanto maior o número de organizações interoperando, menor a performance dos sistemas. A priorização das necessidades e o planejamento estruturado do aumento de participantes pode facilmente eliminar esta restrição.

Segundo Scholl (2005) as restrições tecnológicas e de performance são muito mais fáceis de serem superadas do que as organizacionais, legais, políticas e sociais, que necessitam de mudanças maiores para sua superação. 


\section{METODOLOGIA}

Ao responder a questão de como se dá o processo de interoperabilidade intergovernamental em processos de governo eletrônico, busca-se uma análise de natureza predominantemente descritiva. Já ao questionar sobre qual o impacto na eficiência dos processos, busca-se a compreensão do fenômeno em suas peculiaridades. Godoy (1995) sugere que a análise de caráter qualitativo é mais indicada quando o estudo tem natureza descritiva e busca a compreensão de um fenômeno em sua totalidade e complexidade, que é o caso do escopo do estudo, sendo interessante a evolução da pesquisa utilizando uma metodologia qualitativa.

No entender de Strauss e Corbin (2008), com uma pesquisa qualitativa é qualquer tipo de pesquisa onde se objetiva descobrir ou compreender os fenômenos por trás de eventos a respeito dos quais muito pouco se sabe, ou de maneira a obter novas visões e opiniões acerca daquilo que já se conhece o suficiente, sem utilizar meios diversos de procedimentos estatísticos ou outras ferramentas de quantificação.

Já Chizzotti (2010) considera que o termo qualitativo implica partilhar com pessoas, fatos e locais objetos da pesquisa, extraindo significados que serão traduzidos em texto para apresentar os significados patentes ou ocultos do objeto pesquisado. Partilha-se o pressuposto básico de que a investigação dos fenômenos humanos pode prescindir de quantificações estatísticas para sua análise.

Para Godoy (1995), a pesquisa de natureza qualitativa não visa enumerar ou realizar qualquer tipo de medição dos eventos que toma por objeto, mas parte, antes, de questões amplas que se definem no decorrer do estudo. Dessa forma, muitos elementos relacionados serão percebidos e descobertos apenas durante o processo de pesquisa empírica, de maneira diferente do que acontece com uma pesquisa quantitativa, situação na qual o pesquisador dirige seu trabalho partindo de um plano já estabelecido, anteriormente, lidando com hipóteses objetivamente delineadas e variáveis definidas de maneira operacional. 


\subsection{Estratégia de pesquisa}

Na busca da compreensão de como se desenvolve algo, é adequado utilizar uma abordagem exploratória, que visa proporcionar maior familiaridade com o problema, tornando-o explícito. Para tanto se realiza levantamento bibliográfico e entrevistas com pessoas que tiveram experiências práticas com o problema pesquisado (SILVA e MENEZES, 2001). Da mesma forma a abordagem é recomendada para analisar qual o impacto sobre algo.

Dentre os procedimentos o que mais se adéqua ao escopo é o estudo de caso, pois permite aprofundar e detalhar as situações estudadas, conforme apresentado a seguir.

\subsection{O Método do Estudo de Caso}

Para Yin (2003) o estudo de caso "é uma inquirição empírica que investiga um fenômeno contemporâneo dentro de um contexto da vida real, quando a fronteira entre o fenômeno e o contexto não é claramente evidente e onde múltiplas fontes de evidência são utilizadas". Para o autor, esta definição "mais técnica" oferece melhores critérios para diferenciar o método do estudo de caso de outras técnicas de pesquisa, como o método histórico, o experimental e o survey.

Ainda sobre o estudo de caso, Goode e Hatt (1969) afirmam que o mesmo "não é uma técnica específica. É um meio de organizar dados sociais preservando o caráter unitário do objeto social estudado". Simplificando, Tull (1976) entende o estudo de caso como "uma análise intensiva de uma situação particular". Bonoma (1985), por sua vez, defende que "o estudo de caso é uma descrição de uma situação gerencial".

Segundo Tull (1976), o método do estudo de caso é considerado mais adequado para pesquisas de caráter exploratório. Isto, para Yin (2003), é um dos fatores que podem ter contribuído para a mistificação do mesmo, dificultando o entendimento de sua natureza, bem como o processo através do qual o mesmo é desenhado e conduzido. 


\subsubsection{O uso do Método do Estudo de Caso}

Quando compara o método em questão com outros métodos de pesquisa, Yin (2003) afirma que, para que se dê uma boa definição do método mais adequado a ser utilizado, é preciso, primeiro, que se analise as questões que são postas pela e para a investigação. $O$ Estudo de Caso é útil, especificamente, para responder às indagações de "como" e "por que", de natureza explicativa.

Para Yin (2003), tais questões conduzem ao uso do método de Estudo de Caso porque lidam com relações operacionais que demandam um rastreamento ao longo do tempo, em detrimento de uma simples quantificação de frequência ou incidência.

Contudo, os métodos Histórico e Experimental também têm por objetivo a resposta a tais tipos de perguntas. Entretanto, o Método Histórico é recomendado quando o investigador não tem acesso ou meios de controle dos eventos comportamentais, situação na qual lida (e pesquisa) um passado já "morto" (YIN, 2003). Nessa situação se torna impossível, por exemplo, a tomada de depoimentos de pessoas, limitando as fontes de pesquisa a documentos e outros tipos de artefatos.

Por sua vez, o Método Experimental configura uma situação na qual o pesquisador é capaz de manipular o comportamento diretamente, de forma precisa e sistemática, como ocorre, por exemplo, em experimentos laboratoriais. Neste caso, o fenômeno, como objeto de estudo, é isolado de seu contexto e assim estudado (YIN, 1981).

Não obstante, Yin (2003) entende que o Estudo de Caso deve ser preferido quando o estudo a ser realizado tem como objeto fenômenos contemporâneos, naquelas situações em que os comportamentos relevantes não possam ser manipulados, mas nas quais ainda seja possível realizar observações diretas e entrevistas metódicas e sistemáticas.

Assim, ainda que se assemelhe ao Método Histórico, o Estudo de Caso é caracterizado, principalmente, pela "capacidade de lidar com uma completa variedade de evidências documentos, artefatos, entrevistas e observações". Yin (2003)

No entender de Bonoma (1985) tal método é útil "quando um fenômeno é amplo e complexo, onde o corpo de conhecimentos existente é insuficiente para permitir a proposição de questões causais e quando um fenômeno não pode ser estudado fora do contexto no qual ele naturalmente ocorre". 
Bonoma (1985) afirma que o Estudo de Caso objetiva não a quantificação ou a enumeração, mas a (1) descrição; (2) classificação (desenvolvimento de tipologia); (3) desenvolvimento teórico; e (4) o teste limitado da teoria. Em uma palavra, o objetivo é a compreensão.

Sinteticamente, Yin (2003) define quatro situações em que se deve aplicar o método do Estudo de Caso, quais sejam:

1. De maneira a explicar ligações de causa nas intervenções reais demasiado complexas para serem tratadas através dos "surveys" ou por estratégias experimentais;

2. Para descrever o contexto real em que tal intervenção se deu;

3. Para avaliar, mesmo que de maneira descritiva, a intervenção realizada; e

4. Para que se faça uma exploração das situações em que a(s) intervenção(ões) avaliada não apresente resultados objetivos, claros e/ou específicos.

A respeito da adoção do método do Estudo de Caso em pesquisas na área de sistemas de informação, em especial, Benbasat, Goldstein e Mead (1987, apud Souza, 2000) sustentam que o uso do mesmo é conveniente quando se busca capturar o conhecimento de profissionais e, partindo daí, formular teorias. Segundo os autores, cabe aos acadêmicos aproveitar o conhecimento acumulado originário do processo de tentativa-eerro do qual se valem os profissionais, formalizando-o para então adentrar uma fase de testes (e teorias). Assim, antes que se dê essa formalização do conhecimento, o Estudo de Caso é válido como meio de documentar e arquivar as experiências da vivência real.

\subsection{O projeto de pesquisa com o método do Estudo de Caso}

Yin (2003) conceitua o Projeto de Pesquisa como "a sequência lógica que conecta os dados empíricos às questões iniciais de estudo da pesquisa e, por fim, às suas conclusões". (p.27)

Assim, a elaboração do Projeto de Pesquisa tem influência direta sobre os resultados que serão obtidos, bem como na validade das conclusões as quais o trabalho conduzirá. 
Ainda, o Projeto de Pesquisa atua como guia para o pesquisador, apontando o itinerário a ser seguido.

Essa posição é defendida por Nachmias e Nachmias (apud Yin, 2003), que descrevem o Projeto de Pesquisa como uma planta que:

"guia o investigador no processo de coleta, análise e interpretação das observações. É um modelo lógico que conduz o pesquisador ao formular as inferências a respeito das relações causais entre as variáveis em observação [...] e define [...] se as interpretações obtidas podem ser generalizadas para a população maior ou para situações diferentes."

O Projeto de Pesquisa aborda quatro problemas: (1) quais questões/problemas devem ser estudadas; (2) quais os dados relevantes; (3) quais dados precisam ser obtidos; (4) como proceder para a análise dos resultados. Fica claro, portanto, que o Projeto de Pesquisa aborda os aspectos lógicos da pesquisa, e não os logísticos. Ademais, é um trabalho completo que tem por objetivo conduzir e auxiliar o pesquisador. A seguir é estruturado o projeto de pesquisa.

\subsubsection{Delimitações da pesquisa - questões a serem estudadas}

Uma vez que o estudo de caso é o método indicado para responder a questões como "como" e "porque", de natureza explicativa, é importante, então, que se definam tais questões de maneira clara e precisa.

Recordando a questão de pesquisa deste trabalho frente à literatura estudada fica claro que a dimensão do estudo proposto é inviável para o período de uma dissertação, visto a amplitude de situações a serem abordadas quando se pretende analisar como se desenvolve o processo da interoperabilidade.

Segundo Silva e Menezes (2001), o problema de pesquisa deve ter dimensão restrita para permitir sua viabilidade. Mesmo considerando as restrições oriundas do fato de serem sistemas intergovernamentais em processos de governo eletrônico, uma análise mundial é claramente inviável, bem como da federação brasileira, onde são 27 estados e mais de 5.000 municípios para serem considerados. 
Assim, com a clareza das limitações financeiras e de prazo para a execução dos trabalhos resolveu-se delimitar a pesquisa na relação intergovernamental do estado de São Paulo com seu maior município e capital do estado.

Com 11.253.503 habitantes (Censo 2010, IBGE) São Paulo concentra cerca de um quarto da população do Estado, sendo que ações de governo eletrônico que ocorram no município sempre terão impacto significativo em outros municípios e estados.

Scholl e Klischewski (2007) propõe uma estrutura para a pesquisa sobre interoperabilidade focada em três direções: (1) foco e razões, (2) limitações e restrições e (3) processo e resultados. A principal razão desta proposta é concluir a exploração da fase de construção da teoria sobre o tema, buscando avançar para o teste de hipóteses sobre a teoria construída. A estrutura proposta vai ao encontro das propostas de pesquisa apresentadas neste trabalho. As três direções originam perguntas bem específicas, apresentadas na tabela abaixo:

\section{Tabela 7: Questões relacionadas às direções de pesquisa}

\begin{tabular}{|l|l|}
\hline Direção & Questão relacionada \\
\hline Foco e proposição & O Governo eletrônico busca a interoperabilidade em que áreas e com que propósito? \\
\hline $\begin{array}{l}\text { Limitações e } \\
\text { Restrições }\end{array}$ & $\begin{array}{l}\text { Quais são as restrições e limitações da interoperabilidade em governo eletrônico? } \\
\text { Qual a natureza e características e como elas interagem, contrabalanceiam ou } \\
\text { reforçam uma a outra? Como mitigar estas limitações e restrições? }\end{array}$ \\
\hline $\begin{array}{l}\text { Processo e } \\
\text { resultados }\end{array}$ & $\begin{array}{l}\text { O que leva ao sucesso ou fracasso de um processo de interoperabilidade em governo } \\
\text { eletrônico? Que resultados intencionais ou não são desejados e como tratar os } \\
\text { indesejados? }\end{array}$ \\
\hline
\end{tabular}

Fonte: com base em Scholl e Klischewski, 2007

Ao se analisar a dimensão de foco e proposição, Scholl e Klischewski propõe uma análise tridimensional. Uma primeira dimensão é se a interoperabilidade é para um propósito específico ou geral; a segunda dimensão aborda a frequência da interoperabilidade: permanente ou frequente, ocasional ou pouco frequente e esporádica ou conforme a necessidade. Por fim, a terceira dimensão se baseia em quatro abordagens comuns nos esforços acadêmicos e práticos de interoperabilidade: as que se relacionam com questões de governança, políticas e legais e suas ramificações; as relacionadas com questões financeiras e de financiamento de projetos; dos padrões e premissas inter e intragovernamentais para a interoperação; e as exigências tecnológicas e padrões técnicos para as trocas entre os sistemas. 
No município de São Paulo foram verificadas áreas com possibilidade de estudo no tema proposto e em cada área foi encontrada uma situação de interoperabilidade com o Estado: Na saúde há integração no sistema de distribuição de remédios; na segurança há troca de informações referentes a ocorrências policiais e depredação do patrimônio público; no transporte há a integração dos sistemas de cobrança, através do bilhete único; na educação há complementariedade de esforços no gerenciamento de matrículas; enchentes e trânsito possuem integração no mapeamento de áreas, com troca de informações georreferenciadas.

Porém, algumas áreas possuem restrição ao acesso às informações, seja por questões de sigilo (segurança, saúde e transporte), seja por dificuldade de acesso para a realização da pesquisa (trânsito e enchentes). A área com maior facilidade de acesso às informações é a educação, onde o acesso aos interlocutores se mostrou viável. Dentro da educação, a troca de dados mais significativa ocorre no processo de matrícula escolar do ensino fundamental.

O estudo da matrícula escolar do ensino fundamental possibilita a análise nas três dimensões propostas, possibilitando maior coerência metodológica.

Dessa forma, com a definição do escopo a questão de pesquisa foi redimensionada para:

Como se desenvolve e qual o impacto da interoperabilidade na geração da eficiência em processos intergovernamentais de governo eletrônico entre os sistemas de matrícula escolar do Estado e da cidade de São Paulo?

Apesar da limitação de escopo, a pesquisa ainda apresenta amplo campo de estudo, sendo mantido seu potencial acadêmico.

Portanto, o estudo deste caso em particular, permite verificar quais problemas possam, eventualmente, ter surgido durante o processo de implementação, de que forma foram evitados ou contornados, bem como as melhorias obtidas em razão da troca de informações por interoperabilidade entre os sistemas de matrícula nas escolas municipais e estaduais. 


\subsubsection{Dados relevantes}

Para compreender os impactos na eficiência há a necessidade de compreender, primeiro, o próprio objeto de estudo. Dessa forma, é necessário obter informações sobre como a interoperabilidade influencia nos processos intergovernamentais, bem como analisar como se dá o processo de matrícula no Estado de São Paulo e no município de São Paulo, qual a relação entre estes dois processos e onde a interoperabilidade interferiu. Uma vez conhecidos os processos, cabe verificar se a interoperabilidade foi motivada por uma necessidade de maior eficiência na execução e se esta melhora na eficiência é percebida pelos atores envolvidos, bem como se é efetiva. Por fim, quais ações e situações foram positivas e quais foram negativas no processo de implantação, para que sejam compreendidas as motivações que levaram ao projeto ser concluído satisfatoriamente.

Informações sobre a conjuntura em que o processo ocorreu também podem auxiliar na compreensão do processo. A análise com bases na natureza das barreiras e restrições à adoção da interoperabilidade por governos identificadas na revisão da literatura são um roteiro para o levantamento de informações relevantes, que devem esclarecer sobre estes tópicos.

\subsubsection{Dados a serem obtidos}

$\mathrm{Na}$ literatura podemos encontrar diversos trabalhos sobre interoperabilidade, mas muitos dados necessitam ser obtidos em campo. A descrição simplificada do processo de matrícula pode ser obtida com análise bibliográfica, porém dados sobre o processo de implantação, seus apoios e restrições, e outras informações mais detalhadas que levem à compreensão do modelo utilizado no estado para interoperar os sistemas implica na realização de entrevistas com os atores envolvidos.

\subsection{Proposições e Modelo de Pesquisa}

Para Yin (2003) a definição de proposições é um importante elemento do processo de pesquisa na medida em que a conduzem rumo a certos aspectos que necessitam ser apreciados dentro dos objetivos almejados pelo estudo. 
Podemos conceituar proposições como assertivas que estipulam, de algum modo, relações de cunho teórico entre os fatores examinados pelo estudo.

O autor ressalta que mesmo quando do uso de pesquisas de caráter exploratório, nas quais se objetiva encontrar novas ideias e pressupostos de maneira a explicar eventos ou fenômenos, é importante que se proceda partindo de uma referência na teoria, o que permite que a pesquisa se inicie com lógica e de maneira direcionada, ainda que, posteriormente, as premissas se revelem erradas e sejam abandonadas. Ainda, as proposições não devem ser confundidas com hipóteses de pesquisa, uma vez que não serão comprovadas estatisticamente.

Uma primeira proposição é que o modelo desenvolvido para adoção no Estado de São Paulo segue, em termos gerais, as determinações do e-PING, tendo sido, porém, adaptado para atender às especificidades locais.

Além disso, percebe-se que, apesar de existir, atualmente, uma concordância no que diz respeito à necessidade de integrar sistemas e informações, na prática, a implantação de um modelo de interoperabilidade esbarra em dificuldades e problemas que retardam ou mesmo impedem sua adoção.

Selltiz, Jahoda et. al. (1972) também atentam para o fato de que as preposições de pesquisa devem ser formuladas, no caso de pesquisas exploratórias, de maneira a conservar certa flexibilidade, para que se viabilize a apreciação de várias dimensões do fenômeno.

Nesse sentido, vários autores, como Garda (2011), Santos e Reinhard (2007) levantaram a necessidade da interoperação no Brasil, porém a mesma possui barreiras para adoção.

Uma preposição é a de que as naturezas levantadas por Anderseen e Dawes (1991) servem de base para compreender as barreiras à adoção da interoperabilidade.

Na estrutura de pesquisa proposta por Scholl e Klischewski (2007) baseada em suas três dimensões as naturezas podem ser reconhecidas nas direções da dimensão um, unificando a análise entre os dois autores e ampliando a compreensão do processo.

Ao se verificar a forma como a interoperabilidade está ocorrendo entre os sistemas de matrícula do Estado e Município poderá ser identificada a dimensão e a direção em que se enquadra o processo, permitindo uma visão mais clara das influências que podem surgir sobre o processo, como se vê nas tabelas a seguir: 
Tabela 8: Integração e interoperação para propósitos específicos

\begin{tabular}{|c|c|c|c|c|}
\hline \multicolumn{5}{|c|}{ Desejo ou Necessidade específicos } \\
\hline Frequência & Governança & Economia & Organização & TIC \\
\hline $\begin{array}{l}\text { Ad-hoc } \\
\text { necessária uma } \\
\text { única vez }\end{array}$ & $\begin{array}{l}\text { Baseada em acordos gerais } \\
\text { previamente assinados ou acordos mais } \\
\text { específicos de direitos e procedimentos } \\
\text { de acesso e interoperação }\end{array}$ & $\begin{array}{l}\text { Modesta ou de alto } \\
\text { custo potencial / } \\
\text { retorno baixo, se } \\
\text { houver }\end{array}$ & $\begin{array}{l}\text { Grupos de interesse; } \\
\text { grupo de projeto; força } \\
\text { tarefa (por exemplo } \\
\text { resposta a catástrofes); }\end{array}$ & $\begin{array}{l}\text { Uso de funções e fontes de informação existentes já prontas } \\
\text { para interoperarem; compartilhamento de informação e } \\
\text { interoperabilidade e algum processo transacional ad-hoc, } \\
\text { com baixa eficiência e efetividade. }\end{array}$ \\
\hline $\begin{array}{l}\text { Necessidade } \\
\text { ocasional } \\
\text { frequência } \\
\text { moderada }\end{array}$ & $\begin{array}{l}\text { Com base em acordos específicos de } \\
\text { direitos e procedimentos de acesso e } \\
\text { interoperação }\end{array}$ & $\begin{array}{l}\text { Moderado a alto } \\
\text { custo potencial / } \\
\text { retorno intangível }\end{array}$ & $\begin{array}{l}\text { Grupo de projeto ou } \\
\text { cooperação }\end{array}$ & $\begin{array}{l}\text { Uso de funções novas e preexistentes e fontes de } \\
\text { informações porntas para a interoperabilidade. } \\
\text { Interoperabilidade regular e processamento de transações } \\
\text { com baixo volume e eficiência e efetividade moderadas }\end{array}$ \\
\hline $\begin{array}{l}\text { Necessidade } \\
\text { permanente } \\
\text { frequente }\end{array}$ & $\begin{array}{l}\text { Baseada em acordos específicos de } \\
\text { direito ao acesso e interoperação, } \\
\text { padrões de integração de processos de } \\
\text { negócio, formatos de informação e } \\
\text { procedimentos }\end{array}$ & $\begin{array}{l}\text { Alto custo, retorno } \\
\text { elevado }\end{array}$ & $\begin{array}{l}\text { Grupo de projeto } \\
\text { estendido; federação }\end{array}$ & $\begin{array}{l}\text { Estabelecimentos de padrões para arquitetura de negócios; } \\
\text { funções e fontes de informação para interoperabilidade } \\
\text { existentes são criadas e mantidas regularmente; transações } \\
\text { e interoperabilidade regularmente executadas e com alta } \\
\text { eficiência e efetividade }\end{array}$ \\
\hline
\end{tabular}

Fonte: adaptado de Scholl e Klischewski, 2007 
Tabela 9: Integração e interoperação para propósitos gerais

\begin{tabular}{|c|c|c|c|c|}
\hline \multicolumn{5}{|c|}{ Desejo ou Necessidade Gerais } \\
\hline Frequência & Governança & Economia & Organização & TIC \\
\hline $\begin{array}{l}\text { Ad-hoc / necessária } \\
\text { uma única vez }\end{array}$ & $\begin{array}{l}\text { Baseada em acordos gerais previamente } \\
\text { assinados }\end{array}$ & $\begin{array}{l}\text { Modesto custo /retorno } \\
\text { incerto }\end{array}$ & $\begin{array}{l}\text { Baixa afiliação; Grupos de } \\
\text { interesse; (por exemplo, para } \\
\text { resposta pontual a catástrofes); }\end{array}$ & $\begin{array}{l}\text { Distribuição de informação para } \\
\text { busca; nenhuma ou limitadas trocas } \\
\text { transacionais }\end{array}$ \\
\hline $\begin{array}{l}\text { Necessidade } \\
\text { ocasional ou } \\
\text { frequência moderada }\end{array}$ & $\begin{array}{l}\text { Baseada em acordos gerais previamente } \\
\text { assinados }\end{array}$ & $\begin{array}{l}\text { Modesto para } \\
\text { moderado custo / } \\
\text { retorno intangível }\end{array}$ & Grupo de projeto; cooperação. & $\begin{array}{l}\text { Distribuição de informação para } \\
\text { busca; trocas transacionais modestas }\end{array}$ \\
\hline $\begin{array}{l}\text { Necessidade } \\
\text { permanente } \\
\text { frequente }\end{array}$ & $\begin{array}{l}\text { Baseada em acordos gerais previamente } \\
\text { assinados e acordos específicos de acesso e } \\
\text { direitos e procedimentos para interoperação. }\end{array}$ & $\begin{array}{l}\text { Moderado para alto } \\
\text { custo, retorno } \\
\text { desconhecido. }\end{array}$ & $\begin{array}{l}\text { Grupo de projeto extendido; } \\
\text { federação }\end{array}$ & $\begin{array}{l}\text { Distribuição de informação para } \\
\text { busca; moderada interoperação, } \\
\text { interoperabilidade limitada. }\end{array}$ \\
\hline
\end{tabular}

Fonte: adaptado de Scholl e Klischewski, 2007 
Com base nas informações coletadas sobre o caso, tem-se que a interoperabilidade ocorreu para um propósito específico, com necessidade permanente ou frequente de troca de dados. Assim, segundo a tabela oito devemos encontrar:

- acordos específicos de direito ao acesso e interoperação, padrões de integração de processos de negócio, formatos de informação e procedimentos que darão governança para o processo de interoperabilidade;

- custos elevados de implantação, mas retornos também elevados;

- estabelecimentos de padrões para arquitetura de negócios; funções e fontes de informação para interoperabilidade criadas e mantidas regularmente; transações e interoperabilidade regularmente executadas e com alta eficiência e efetividade.

Por fim, o levantamento teórico realizado permitiu a formulação dos seguintes proposições:

- a interoperabilidade leva ao aumento da eficiência governamental ao integrar processos e eliminar os casos de duplicação de processos em localidades distintas;

- os principais desafios para a implantação da interoperabilidade são de natureza organizacional;

- a principal dificuldade técnica quando da implantação da interoperabilidade é a coerência dos conjuntos de dados;

- a influência política e a definição clara de ações de cada ente federado nos processos compartilhados garante maior efetividade do processo.

A validade destas proposições será verificada após a análise dos dados coletados tanto nas entrevistas quanto na análise de documentação.

\subsection{O Caso}

O caso aqui analisado trata da interoperabilidade construída entre o JCA - sistema de matrículas do Estado de São Paulo - e o EOL, sistema de gerenciamento escolar do município de São Paulo.

A necessidade de integração de dados entre os dois sistemas se impôs no final de 2009 e início de 2010, quando se constatou que 40 mil das matrículas feitas para o Ensino 
Fundamental na capital não haviam se concretizado. A partir da crise gerada por essa situação, Governador e Prefeito se reuniram com seus respectivos secretários de Educação e concluíram que o problema fora causado pela dificuldade de troca de informações entre os sistemas municipal e estadual.

Até então, tal troca se procedia da seguinte forma: para a renovação de uma matrícula, o Município enviava um arquivo que era analisado pelo Estado, que retornava outro arquivo com as incongruências encontradas, para que fossem corrigidas e reenviadas. Para as novas matrículas, a secretaria de cada escola acessava os dois sistemas e digitava as informações.

Com o objetivo de agilizar e melhorar esse processo, foi desenvolvida uma camada de integração; foram criados web services para interligar o EOL a essa camada de integração, bem como robots que transferissem essas informações para o JCA.

As entrevistas efetuadas no curso deste trabalho possibilitaram o estabelecimento de uma linha histórica de desenvolvimento do caso; a análise documental realizada permitiu a coleta de informações específicas sobre as soluções adotadas, bem como informações sobre a interferência para que o processo fosse realizado em um período de tempo menor em relação àquele que é padrão no Estado. A interoperabilidade entre os sistemas, ainda que apenas parcial, buscou eliminar a necessidade de dupla digitação por parte das secretarias escolares e simplificar o processo de rematrícula.

Ressalve-se que a interoperabilidade ocorre apenas entre esses dois sistemas, sendo que há muito mais a interoperar, tanto na Educação, como no Estado como um todo.

\subsection{Coleta de Dados}

Segundo Yin (2003) há seis fontes de evidências que podem ser utilizadas para a coleta dos dados necessários para um Estudo de Caso: documentos, registros de arquivos, entrevistas (abertas, fechadas e levantamentos), observação direta, observação participante e artefatos físicos.

Neste trabalho, utilizaram-se entrevistas de natureza qualitativa, além da análise de documentos, registros, artigos de jornais, vídeos de reportagens, relatórios internos dos órgãos, apresentações em PowerPoint, imagens e diagramas que ilustram o trabalho 
realizado. As entrevistas realizaram-se com participantes do processo, onde foram definidos seis grupos de atores que participaram, em algum momento, do processo: dirigentes do Estado (Secretários municipal e Estadual de educação, Governador e Prefeito), que foram responsáveis por garantir politicamente a realização do projeto; integrantes da Secretaria de Estado da Educação e da Secretaria Municipal de Educação, que foram diretamente afetados pelo projeto e que tiveram o maior impacto dos resultados; integrantes da Prodesp, da Prodam e do Projeto Integração de sistemas do Estado, responsáveis por definir e realizar tecnicamente o projeto. Destes grupos, foram entrevistados:

1. Dirigentes do Estado:

a. Secretário Municipal de Educação;

b. Chefe de Gabinete da Secretaria de Educação do Estado;

2. Integrantes da Secretaria de Estado da Educação:

a. Coordenador do GDAE;

b. Responsável pelo JCA;

3. Integrantes da Secretaria Municipal de Educação:

a. Assessor técnico da Secretaria de Educação do Município, responsável pelos sistemas de gestão e matrículas (EOL);

b. Diretor de Escola Municipal de Ensino Fundamental

4. Integrantes da Prodam:

a. Gerente de contas Prodam para Secretaria municipal de Educação;

b. Assessor Executivo da Prodam

5. Integrantes da Prodesp:

a. Diretor de atendimento, Prodesp;

b. Desenvolvedor Prodesp locado na Secretaria de Educação do Estado, responsável pelos sistemas de matrícula e acompanhamento escolar;

6. Integrantes do Projeto de integração do Estado:

a. Corregedor Geral da Administração; 
b. Presidente do Cepam - Centro de Estudos e pesquisas da Administração Municipal;

c. Superintendente de Processos e Tecnologia para Governo da FDTE - Fundação para o Desenvolvimento Tecnológico da Engenharia;

Yin (2003) defende que entrevistas são uma importante fonte de evidências para o estudo de caso, na medida em que os mesmos lidam, comumente, com atividades de pessoas e grupos, como é o caso em questão, em que diversas instituições e órgãos governamentais estão envolvidos.

Tais entrevistas foram conduzidas a partir de um roteiro composto por seis questões abertas, de maneira a permitir maior flexibilidade nas respostas, necessária devido à natureza exploratória da pesquisa realizada, permitindo a originalidade das respostas.

Segundo Boni e Quaresma (2005) a técnica de entrevistas abertas é adequada para o detalhamento de questões e formulação mais precisa de conceitos, servindo para explorar questões com maior profundidade e dando liberdade ao entrevistado para discorrer sobre o assunto ou questão em análise, sendo as perguntas respondidas dentro de uma conversação informal.

\subsection{O Roteiro para a Entrevista}

A elaboração do roteiro para as entrevistas deu-se a partir das proposições iniciais de pesquisa, já mencionadas, bem como do modelo de pesquisa elaborado e das informações relevantes encontradas durante a revisão da literatura.

Scholl e Klischewski (2007) propõe questões específicas para cada uma das três dimensões que analisam na proposta de arquitetura de pesquisa para interoperabilidade. São questões que focalizam o universo geral de pesquisa em interoperabilidade, mas que podem ser avaliadas para adequar as questões específicas do caso de forma a gerar informação generalizável. São elas:

Foco e proposição:

- Quais as áreas onde a integração e interoperação são mais frequentes?

- Quais são os desejos e necessidades mais ou menos aparentes? 
- Que tipos de organização são mais ou menos frequentes e em que áreas?

Limitações e restrições

- Qual a influência das limitações e restrições?

- O que mitigou as limitações e restrições?

- Que outras limitações, restrições, catalisadores ou inibidores podem ser identificados?

Processo e resultados

- Que indicadores de sucesso, se existirem, são usados na prática?

- Como é definido sucesso ou fracasso?

- Como comparar indicadores entre casos?

- Que medidas de sucesso / fracasso são geralmente aceitas?

- Como são distribuídos os resultados, em termos da matriz de resultados apresentada?

Todas estas questões complementam o objeto do trabalho, em especial as questões relativas a limitações e restrições e processo e resultados.

Com base nas informações levantadas foram elaboradas perguntas para servirem como fio condutor das entrevistas, não limitando a resposta do entrevistado ou conduzindo-a. Com as perguntas abertas foi dada liberdade para o entrevistado divagar, pois o fato do entrevistado ficar a vontade gera uma maior riqueza de relatos. Desta forma, às vezes não foi possível seguir o roteiro à risca, servindo esse apenas como fio condutor do processo.

As perguntas do roteiro são as apresentadas abaixo:

- Como começou? O que motivou a interoperabilidade entre os sistemas?

- Qual foi a sua participação no processo?

- Como aconteceu? Na sua visão, como o projeto se desenrolou?

- O que auxiliou para que o projeto avançasse? Consegue definir fatores que influenciaram positivamente e fatores que influenciaram negativamente no projeto? Como foram minimizados os fatores negativos?

- Na sua visão, como foram os resultados da interoperabilidade para a eficiência do processo? Consegue citar vantagens obtidas? Há desvantagens? 
- Você visualiza novas ações para ampliar a interoperabilidade entre os sistemas educacionais, em especial o de matrículas escolares? O que mais há para desenvolver?

A primeira pergunta do roteiro visa estabelecer a compreensão do entrevistado sobre o caso em análise, quais suas restrições e compreender diferentes posições sobre um mesmo fato.

A segunda pergunta busca contextualizar o entrevistado, definindo os limites de sua participação.

A terceira pergunta busca gerar o máximo de informação sobre o conhecimento do entrevistado quanto a mudanças no processo, ou seja, sobre como se desenvolveu o projeto de interoperabilidade como um todo.

Na quarta pergunta mantém-se o foco em como o processo foi realizado, mas começa-se a buscar o conhecimento sobre os resultados do projeto.

A quinta pergunta foca diretamente nas informações sobre qual o impacto da interoperabilidade na eficiência dos processos, estabelecendo a base para compreender os resultados do projeto dentro do escopo do estudo. Na quinta pergunta busca-se, através do contraditório, compreender melhor os aspectos que foram atendidos pelo processo e os não atendidos, sendo que a melhoria da eficiência do processo pode ser questionada por respostas levantadas nesta questão, mesmo que de forma indireta. É aqui que também se procura estabelecer a percepção do entrevistado sobre as mudanças no processo geradas pela interoperabilidade dos sistemas.

A quinta pergunta também permite obter informação para a construção da matriz de resultados de Scholl e Klischewski (2007), que os classifica conforme o sucesso e desejo:

Tabela 10; Resultados potenciais de projetos de interoperabilidade em e-Gov

\begin{tabular}{c|c|c|} 
& Desejável & Indesejável \\
\hline Sucesso & Resultado não problemático & Resultado problemático \\
\hline Fracasso & Resultado problemático & Resultado não problemático \\
\hline
\end{tabular}

Fonte: Scholl e Klischewski, 2007 
A sexta pergunta procura contextualizar melhor os resultados obtidos, procurando determinar outros resultados desejados, mas que não foram atingidos ainda.

Estas perguntas servem como roteiro para orientar a entrevista, sendo que durante as entrevistas foram realizadas outras perguntas de acordo com o relato desenvolvido, de maneira a gerar o máximo de esclarecimento sobre todos os aspectos do caso. Também foi dada liberdade para a divagação sobre os assuntos debatidos, visando deixar o entrevistado mais relaxado.

Ao final, as entrevistas foram transcritas e analisadas conforme o conteúdo, gerando agrupamentos sobre diversos temas. Os agrupamentos com informações relacionadas com o escopo do estudo foram utilizados durante a análise do caso, seja para ilustrar o histórico de implantação, seja para corroborar ou negar as proposições formuladas. As entrevistas foram mantidas na integra para consulta no anexo 1, ao final deste trabalho. Com isso pretende-se também disponibilizar um material rico para consultas e formulação de trabalhos posteriores.

\subsection{Ligação entre os Dados e as Proposições}

Para se proceder à análise dos dados obtidos por meio das entrevistas tomou-se por base tanto o projeto de pesquisa como um todo quanto os procedimentos adequados ao Estudo de Caso, com a finalidade de relacionar as informações trazidas pelas entrevistas com as proposições inicialmente estabelecidas.

De acordo com Yin (2003), para tanto, torna-se imperativo estabelecer uma estratégia geral de análise: "O objetivo final da análise é o de tratar as evidencias de forma adequada para se obter conclusões analíticas convincentes e eliminar interpretações alternativas".

O mesmo autor elenca os modelos mais usados:

Padrão Combinado: um dos métodos mais recomendados consiste na comparação entre os padrões empíricos e os previstos. A coincidência entre estes contribui para o aumento da validade interna do Estudo de Caso. Quando se tratar de estudo explanatório, a comparação pode ser estabelecida entre os padrões e as variáveis dependentes e interdependentes. 
Elaboração de Explicações: nesse caso, a intenção é proceder à análise do Estudo de Caso, elaborando explicações sobre o mesmo. De acordo com Yin (1981), a elaboração de explicações constitui-se: do estabelecimento preciso de uma relação com os elementos do caso; da consideração de possibilidades de explicações alternativas; da elaboração de explicações lógicas, que conduzam a conclusões adequadas aos fatos do caso.

Distinção entre Notas e Narrativas: procedimento que evita que o relato feito a partir de uma entrevista individual, reunião, documentos ou relatórios seja influenciado pela forma de redação, prejudicando a análise das evidências. Os relatos devem, sempre, se ater apenas aos fatos.

Tabulação dos Eventos Significativos: os dados que refletem os eventos mais importantes do Estudo de Caso podem ser tabulados de acordo com um método, estabelecido pelo pesquisador. O procedimento é recomendável no caso de terem sido utilizados categorias ou códigos. No entanto, Yin (1981) alerta para o fato de que podem surgir dificuldades de análise quando as categorias utilizadas pelo pesquisador forem muito pequenas ou muito numerosas.

No presente estudo, dois foram os modelos utilizados: o padrão combinado, para confrontar os problemas relacionados à interoperabilidade detectados na revisão da literatura àqueles percebidos no caso e a elaboração de explicações, realizadas na própria narrativa do caso. Para tanto as entrevistas foram esmiuçadas e referenciadas quando da elaboração do histórico da implantação do projeto, bem como foram pinçadas as informações que corroboram ou negam as proposições. Por fim, buscou-se a análise conforme os padrões definidos na revisão bibliográfica, permitindo uma análise mais profunda dos mecanismos que influenciam na implantação..

\subsection{Apresentação e Análise do Caso}

Yin (2003) aponta que, quando da elaboração do relatório de apresentação do caso, para que se dê o efetivo Estudo de Caso, deve-se manter atento para alguns aspectos:

- A diversidade de possíveis construções para os relatos de Estudos de Caso;

- A forma das ilustrações para o estudo de caso; 
- Os procedimentos a serem seguidos quando da construção;

- As características fundamentais de um relatório adequado e objetivo, que deve cobrir o projeto e o conteúdo.

Com base nos relatos e documentos obtidos e analisados, foi desenvolvida a narrativa do caso, iniciando-se nos acontecimentos que antecederam o caso em si, mas que influenciaram o desenrolar das atividades, seguindo até o final de 2011, quando os sistemas se encontravam no estágio de desenvolvimento atual. Nas conclusões do trabalho serão citados desenvolvimentos futuros previstos para os sistemas, pois são conjecturas sobre o desenrolar futuro dos trabalhos, não havendo embasamento de que os sistemas seguirão na direção apontada nas entrevistas (algumas até conflitantes).

\subsection{Critérios para Interpretar os Resultados e Limitações da Pesquisa}

Para Yin (2003), é frequente encontrarmos críticas ao método do estudo de caso, considerado "fraco" pelos pesquisadores sociais, que entendem que os resultados obtidos através desse método não podem ser generalizados de maneira a explicar uma situação maior. Por outro lado, Yin defende que problemas semelhantes podem ser encontrados mesmo quando do uso de métodos experimentais, tendo em vista que também não é possível generalizar informações partindo de um único experimento. Para o autor, fatos científicos devem ser embasados em diversos experimentos, replicando um único fenômeno sob condições diferenciadas.

Assim, o mesmo raciocínio pode ser utilizado nos estudos de caso (a replicação analítica e teórica). Dessa forma, os estudos de caso, assim como os experimentos, podem ser generalizados em proposições teóricas, mas não para populações ou universos.

Segundo Yin (2003), sob essa perspectiva, um caso não é a representação de uma amostra, e cabe ao pesquisador expandir e generalizar as teorias (generalização analítica) e não enumerar ou medir frequências (generalização estatística).

Dessa maneira, os resultados deste trabalho não podem ser generalizados estatisticamente, mas sim de maneira analítica, tendo em vista as dimensões e aspectos de sua construção e desenvolvimento. Disto, entende-se que o usuário desta pesquisa é o indivíduo mais indicado para realizar uma avaliação externa ou, em outras palavras, analisar se o caso 
aqui apresentado, bem como os resultados encontrados pela pesquisa, empregam-se ao seu caso (validade externa). Da mesma forma, Stake (2005) sugere que o estudo de caso seja submetido à análise crítica de membros avaliadores, permitindo clarificar o sentido com múltiplas percepções. No entanto, não foi possível esta análise, sendo que o caso em questão deve ser analisado com a clareza de que podem ocorrer vieses de interpretação causados pela limitação do pesquisador.

Por outro lado, há a questão da validade interna do estudo de caso, bem como o rigor da pesquisa. Desta forma, tomaram-se precauções quando da condução da pesquisa, elencadas abaixo:

- elaboração de um roteiro para dirigir as entrevistas;

- as entrevistas foram conduzidas pelo próprio pesquisador, que revisou as transcrições;

- utilizaram-se múltiplas fontes de evidência (triangulação), de maneira a confirmar ou complementar as informações obtidas através das entrevistas.

Quanto às limitações da presente pesquisa, no que diz respeito ao método empregado, podem ser citadas as que seguem, baseadas nos entenderes de Bido (apud Souza, 2000):

- Mesmo com todas as precauções tomadas quando da realização das entrevistas, é importante considerar que os resultados têm uma natureza parcial, não representando a totalidade do fenômeno objeto de estudo;

- A descrição do caso, por parte dos entrevistados, foi obviamente influenciada por suas opiniões.

Por fim, há de se ter em mente que nem todos os dados e fatos importantes para a pesquisa se encontravam disponíveis em registros ou documentos, tendo a memória dos entrevistados desempenhado papel relevante ao processo, o que pode levar à imprecisão das informações e/ou à falta das mesmas.

Nesse tipo de pesquisa a opinião do pesquisador pode se tornar um empecilho para o julgamento correto dos fatos e seus desmembramentos, como mostrado na metodologia. Para minimizar essa influência, procurou-se privilegiar as entrevistas e as opiniões apresentadas pelos entrevistados. O caso foi basicamente construído sobre estas entrevistas, pois há muito pouco material de consulta, apenas os relatórios oficiais do desenvolvimento da interoperabilidade entre os sistemas, algumas ilustrações e diagramas 
e parcas notícias que fizeram referência direta aos problemas levantados. Algumas reuniões, fundamentais para a compreensão do caso, não foram registradas em ata, reforçando o fato de o principal conteúdo ser oriundo das entrevistas. Por esse motivo, foram mantidas as falas originais dos entrevistados na concatenação de ideias e descrição do caso, de forma a gerar fluidez entre as diferentes entrevistas e facilitar a compreensão. Também, buscando uma maior facilidade da leitura, a origem política e a origem tecnológica do caso foram descritas separadamente, mas referenciando os pontos de intersecção. Dessa forma, ficou mais fácil compreender as implicações das duas áreas no desenvolvimento do processo.

O caso está dividido em capítulos. No primeiro, é apresentado o estudo bibliográfico sobre a interoperabilidade no estado. Em seguida são apresentadas as ações dentro do núcleo político que levaram à decisão de: pensar a interoperabilidade na educação entre o Estado e o município. O capítulo seguinte focaliza as tomadas de decisão dentro do núcleo técnico, que justificam a forma como a interoperabilidade foi construída entre os sistemas, quais os problemas enfrentados pela equipe técnica e como foram superados; em seguida, a descrição dos sistemas e suas características; após, o levantamento dos pontos técnicos que facilitaram ou dificultaram a construção da interoperabilidade entre os sistemas. Por fim, é apresentada a solução adotada e como foi realizada a implantação. No capítulo de resultados, enfocam-se as consequências da interoperabilidade entre os sistemas apresentadas pelos entrevistados envolvidos com o sistema após a implantação, bem como suas visões do que falta melhorar no processo. Finalmente, é analisado o processo frente à sua eficiência corroborando ou não com as proposições levantadas e apresentando as conclusões. 


\section{PESQUISA EMPÍRICA}

Para a apresentação do caso, inicialmente será apresentada a evolução da interoperabilidade no Estado de São Paulo baseada em estudo bibliográfico. Em seguida é apresentada uma descrição do caso, construída com base em entrevistas e em documentos coletados.

\subsection{Interoperabilidade no Estado de São Paulo}

Em 1994, a implantação de sistemas gerenciais de governo passou a ser uma prioridade no Estado de São Paulo, acompanhando o que se iniciava no governo federal. O SIAFEM, derivado do SIAFE Federal, gerenciava o orçamento e a execução financeira de todos os órgãos do Estado. Foi desenvolvida a BEC, sistema de compras também unificado e outros sistemas voltados para as áreas fim, como o GDAE, sistema de Gerenciamento Escolar desenvolvido em 1995 para organizar as informações sobre escolas, alunos, professores, salas de aula, matrículas, frequência escolar, etc. Porém, ainda não se pensava em comunicação entre sistemas e, apesar da clara melhoria de desempenho com o alinhamento de informações entre as diversas Secretarias de Estado, os processos continuavam segmentados, mantendo-se o isolamento.

No Estado de São Paulo a mudança de visão se iniciou em 1997, quando foi inaugurado o primeiro Poupatempo, que agrupava diversos serviços de governo em um único lugar. O objetivo era facilitar a vida do cidadão, que não precisaria se deslocar para diversas repartições, podendo realizar todo o atendimento em um único local. No entanto, continuou não havendo troca de informação entre os diversos serviços, como o simples compartilhamento de endereço do cidadão ou a emissão conjunta de documentos.

Dias (2008), analisando o período de governo no Estado de São Paulo de 1994 até 2006, encontrou relação entre o uso de Tecnologias da Informação e a evolução da Reforma da Administração Pública que, se por um lado foi variável ao longo dos doze anos analisados, "de modo geral a análise do caso mostra o significativo papel desempenhado por Tecnologia da Informação no Governo do Estado de São Paulo, e a forte relação entre as políticas de Tecnologia da Informação e administração" (DIAS, 2008). Segundo a autora, a influência da Nova Gestão Pública garantiu que os sistemas estaduais 
evoluíssem para um modelo que integrava horizontalmente e por função (compras, orçamento, protocolo, etc.), apesar de não haver, ainda, a integração por processos.

Durante o período de 2002 a 2006, a partir do programa de cooperação @LIS (COMMISSION, 2004) - Alliance for the Information Society, lançado pela Comissão Europeia para auxiliar no desenvolvimento da "Sociedade da Informação" na América Latina, foi desenvolvido o primeiro trabalho de integração no Estado, o e-GOIA (EUROPEAID CO-OPERATION OFFICE, 2006).

Segundo Garda (2011), o e-Goia nasceu da crescente necessidade do governo converter o relacionamento presencial com o cidadão para uma interação eletrônica mais eficiente e eficaz. Com o projeto visava-se estabelecer formas diversas de acesso aos serviços públicos, revisando processos internos de forma a diminuir a burocracia e integrar ações, tornando o governo mais transparente para o cidadão.

Ainda segundo Garda (2011), o projeto objetivava desenvolver o governo eletrônico para acesso de cidadãos de baixa renda, buscando um espaço único na Internet no qual os cidadãos pudessem interagir com o poder público e entre si, bem como ter acesso aos serviços públicos virtualmente. No entanto, o projeto conseguiu apenas produzir um sistema de demonstração, sendo abandonado em 2006.

Em 2007, a partir de uma necessidade detectada na Corregedoria Geral da Administração, órgão ligado à Casa Civil do Estado de São Paulo, o governo iniciou um trabalho de avaliação para verificar qual a melhor solução para integrar sistemas e processos relacionados com as áreas de controle da corregedoria, em especial a execução orçamentária, a contratação de serviços, as compras de produtos e os convênios com municípios e entidades filantrópicas. Desse estudo verificou-se que a interoperabilidade entre os sistemas era uma solução mais viável que o desenvolvimento de um novo sistema integrado, um ERP estadual, que era a ideia original. Assim, em 2008 se iniciou o desenvolvimento do modelo e especificação da plataforma de integração com os requisitos de interoperabilidade dos sistemas de controle público em uso pelo Estado e destes com os sistemas municipais (ALBUQUERQUE FILHO e PESSI, 2010). O modelo aprofundava o e-PING, buscando adequar o modelo federal à realidade estadual e definir algumas soluções tecnológicas a serem adotadas.

O projeto abordava a questão de integração, que surgiu com a constatação da Corregedoria Geral da Administração do Estado de São Paulo de que os sistemas do 
Estado não forneciam informação suficientemente consolidada para permitir uma análise clara das ações objeto de diligências. Segundo o Presidente da Corregedoria na época, "apesar de existirem sistemas e dados em profusão, a falta de comunicação entre esses (sistemas) impede a correlação, exigindo dos corregedores um trabalho braçal de análise manual das informações" (ALBUQUERQUE FILHO e PESSI, 2010). Com a elaboração do modelo, pretendeu-se apresentar para o Estado uma solução para facilitar a comunicação necessária entre os sistemas. A partir do modelo desenvolvido, foram verificadas as opções de soluções que poderiam ser adotadas em contraponto à solução escolhida pela Corregedoria, bem como analisada, dentro do modelo de interoperabilidade adotado, a relevância de se trabalhar tendo processos como foco.

Ao se analisar o governo com base em processos, e não em atividades e/ou funções, quebrou-se a visão tradicional por estrutura hierárquica, característica de análises governamentais. Segundo Enoki:

\footnotetext{
Enquanto uma estrutura hierárquica é, tipicamente, uma visão fragmentada e estática das responsabilidades e das relações de subordinação, a estrutura por processo é uma visão dinâmica da forma pela qual a organização produz valor. A visão do processo evidencia a sequência de atividades que são realizadas, cruzando departamentos e níveis hierárquicos, até a saída dos produtos (ENOKI, 2006).
}

Com isso, a visão burocrática se transforma. Não que as regras deixam de existir, mas passam para outro nível de interação.

O modelo estadual parte da e-PING, porém estabelece alguns detalhes sobre metodologias a serem adotadas que não são foco do modelo federal, por particularizarem a solução. A intenção foi não contrapor as arquiteturas, situação que apenas dificultaria o desenvolvimento das interoperações com o governo federal. Assim, adotando-se as recomendações da e-PING, o governo do Estado procurou apresentar um modelo estruturado e uma metodologia de implantação que pudesse ser facilmente executada. Tomou por base as experiências bem sucedidas nos sistemas bancários e desenvolveu um modelo que prevê a revisão de processos e a interoperabilidade a partir de uma camada de integração. 


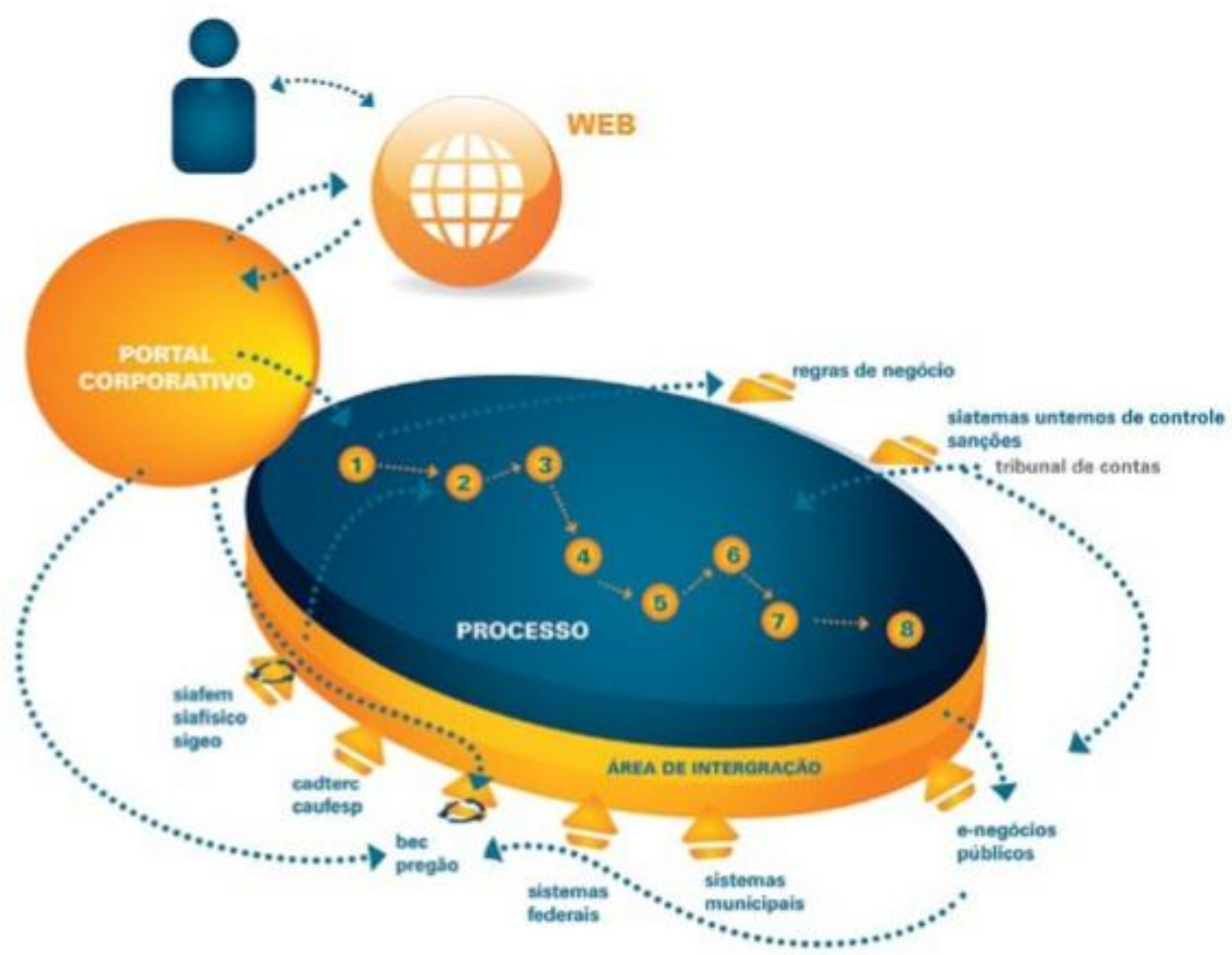

Figura 1: A camada de integração.

Fonte: ALBUQUERQUE FILHO e PESSI, 2010

A figura 1 apresenta o modelo de interoperabilidade utilizando uma camada de integração com uma interface baseada em processos e unificada para o usuário. O modelo de interoperabilidade desenvolvido no Governo do Estado de São Paulo determina que a integração dos sistemas de suporte à gestão, com sistemas operacionais, deve ser feita por meio de um ambiente único de integração, comumente denominado camada de integração (ALBUQUERQUE FILHO e PESSI, 2010). Este é, na realidade, um dos principais desafios na construção de uma plataforma para sistemas de informações para gestão, sendo necessária atenção especial à arquitetura de informações que suportará os processos de gestão (modelagem de dados, objetos e componentes do repositório central). Uma arquitetura de software é um conjunto de declarações que descrevem seus componentes e associam funcionalidades de um sistema a estes componentes. Descreve a estrutura técnica, restrições e características, bem como as interfaces existentes entre seus componentes. A arquitetura é o projeto básico para o sistema e, portanto, o plano de alto nível implícito para sua construção (ALBUQUERQUE FILHO, 2009). É importante 
implantar uma arquitetura de integração de informações que compatibilize modelos de dados diversos e de difícil manipulação. Esta arquitetura deverá ser construída com princípios de abstração que garantam flexibilidade e perenidade, absorvendo, sem dificuldades, quaisquer novas demandas ou inserções de sistemas transacionais, ao mesmo tempo em que deve proporcionar alto desempenho no tratamento das informações (Governo Eletrônico, 2009). Com a arquitetura proposta, todos os sistemas são referenciados em uma base comum, como se fosse uma base integrada e única, mas com “apontadores" (pointers) para cada conteúdo específico.

Ainda dentro do modelo, foram definidas formas de interoperabilidade a serem preferencialmente utilizadas, como o uso de web services, que são definidos como aplicações de software cujas interfaces e ligações são capazes de serem definidas, descritas e descobertas por artefatos baseados em XML (KAO, 2001). Além disso, possuem suporte para integração direta com outras aplicações de software, utilizando, como padrão de interoperabilidade, mensagens escritas em XML e encapsuladas em protocolos de aplicação padrão da Internet.

A necessidade de integração entre os diversos sistemas de informação de governo, desenvolvidos em diferentes tecnologias, às vezes de forma simultânea e em tempo real, implica na adoção de um padrão de interoperabilidade que garanta escalabilidade e facilidade de uso. Podem ser transformados em Web services desde um formulário pertencente a uma página web, até um componente de software, que encapsula uma complexa regra de negócio, o que torna seu uso bastante flexível, contemplando tanto transferências de documentos entre instituições, como solicitações para execução de serviços remotos. Contudo, em algumas situações, os sistemas não permitem esta forma de integração. Nestes casos em que a tecnologia não for aplicável, é proposto que as várias interfaces (telas) com usuários sejam acessadas por "robots" de interface, que simulam a operação manual de um operador do sistema, recebendo as informações (na interface comum) e as transferindo para as interfaces dos correspondentes sistemas préexistentes, sem que estes tenham que ser alterados. 


\subsection{O caso das Matrículas Escolares no Estado de São Paulo}

O Estado de São Paulo é responsável, anualmente, por gerenciar cerca de 10 milhões de matrículas, um quinto do total nacional. Destas, seis milhões são de ensino fundamental ( $1^{\circ}$ ao $9^{\circ}$ ano) e 1,7 milhões são matrículas de educação infantil (creche e pré-escola). Deste montante cerca de dois milhões e meio acontecem no município de São Paulo.

A matrícula no Estado de São Paulo começa por um processo denominado matrícula antecipada, que busca garantir a manutenção do atendimento e continuidade dos estudos aos alunos já matriculados e o atendimento planejado de novas demandas. Após a matrícula antecipada, são chamados os novos alunos ingressantes no sistema. Em 2009, um erro de comunicação entre os sistemas do Estado e do município, em São Paulo, deixou 40 mil crianças sem matrícula definida. Aproximadamente uma em cada 60 crianças ficou sem matrícula, o que gerou uma grave repercussão nos meios de comunicação. Com a pressão sobre os secretários de educação do estado e do município, os técnicos foram obrigados a buscar uma solução para o problema, sendo proposta a interoperabilidade para que os dados pudessem ser conferidos em tempo real. O serviço foi implantado, gerando impacto direto nos usuários dos sistemas nas escolas municipais e na operação dos sistemas pelas equipes internas das secretarias.

A partir dos relatos obtidos nas entrevistas foi possível reconstituir o histórico de como os fatos ocorreram, de modo que houvesse um ambiente propício para a realização da interoperabilidade entre os sistemas de matrícula Estadual e Municipal no município de São Paulo.

\subsubsection{O processo de matrícula no Estado de São Paulo}

A matrícula no Estado de São Paulo é organizada anualmente a partir de resoluções da Secretaria Estadual de Educação. Em 2010 a matrícula foi regida pela resolução $S E n^{\circ} 55$, de 11 de agosto de 2009. Em seu artigo $1^{\circ}$ a resolução define que as ações para a efetivação do processo de atendimento à demanda escolar do ensino fundamental, para o ano de 2010, deveriam respeitar os seguintes procedimentos: (I) matrícula antecipada dos ingressantes no ensino fundamental e chamada escolar de 
crianças e adolescentes, candidatos ao ensino público; (II) - manutenção do atendimento aos alunos já matriculados, em continuidade de estudos.

As etapas da matrícula antecipada são detalhadas no artigo $3^{\circ}$ e consistem de:

I - o cadastramento dos alunos demandantes de vaga no ensino fundamental público;

II - a programação conjunta da oferta de vagas em escolas estaduais e municipais, para o ano letivo de 2010;

III - a compatibilização entre a demanda e as vagas disponíveis;

IV - a efetivação da matrícula dos alunos;

V - a divulgação dos resultados para a comunidade.

De 1 a 30 de setembro de 2009 foram matriculadas as crianças que completaram seis e sete anos até 30 de junho de 2010, tanto as que frequentavam quanto as que não frequentavam a pré-escola municipal, no $1^{\circ}$ e $2^{\circ}$ ano do fundamental, respectivamente. No mesmo período foram matriculadas as crianças com oito anos ou mais que se encontravam fora da escola pública, candidatos a qualquer série/ano, inclusive em classes de educação de jovens e adultos (EJA).

No período de 20 de outubro a 23 de novembro as matrículas foram reabertas, para atender alunos que não conseguiram realizar a matrícula no período anterior.

A programação de vagas de todas as escolas estaduais e municipais deveria ser realizada exclusivamente por meio da digitação da coleta de classes no Sistema de Cadastro de Alunos da Secretaria de Estado, após planejamento conjunto do atendimento escolar para o ano letivo de 2010, assegurando a continuidade de estudos dos alunos já matriculados. A matrícula só se efetivava após a compatibilização demanda/vaga, mediante a digitação da formação das classes e a efetivação da matrícula no Sistema de Cadastro de Alunos da Secretaria de Estado.

No entanto, a resolução permitia novas matrículas durante todo o ano letivo de 2010 , desde que devidamente registrados no cadastro de alunos do estado.

$\mathrm{O}$ atendimento à demanda do Ensino Fundamental no Estado de São Paulo seguiu o seguinte cronograma: 
Até 21/08/2009 - Orientação, pelas Diretorias de Ensino, às escolas estaduais e Órgãos Municipais sobre procedimentos para a matrícula antecipada, objetivando o planejamento conjunto de vagas para o atendimento escolar do ano letivo de 2010.

01 a 22/09/2009 - Coleta de classes de todos os níveis de ensino, previstas para o ano letivo de 2010, das escolas estaduais e municipais. As Diretorias de Ensino foram responsáveis por gerar os números de classes e digitar o quadro resumo das escolas estaduais de sua jurisdição, no Sistema de Cadastro de Alunos, de acordo com o planejamento prévio homologado pelas Coordenadorias de Ensino.

01 a 30/09/2009 - Fase I - Definição, no Sistema de Cadastro de Alunos da Secretaria de Estado, dos alunos que, em 2009, frequentavam a última etapa da pré-escola nas escolas públicas municipais ou conveniadas e que deveriam ser atendidos no ensino fundamental público.

01 a 30/09/2009 - Fase II - Chamada escolar e cadastramento, nas escolas públicas, de candidatos ao ensino fundamental que não frequentavam, em 2009, escola de educação infantil pública; digitação completa ou complementação da Ficha Cadastral dessas crianças no Sistema de Cadastro de Alunos do Estado, com especial atenção para as informações relativas ao endereço completo, tendo em vista o encaminhamento de correspondência.

01 a 30/09/2009 - Fase III - Chamada escolar e cadastramento nas escolas, das crianças e jovens que se encontravam fora da escola pública, com idade a partir de 8 (oito) anos completos em 2009, candidatos à matrícula em qualquer série do ensino fundamental, inclusive na modalidade de educação de jovens e adultos; digitação completa ou complementação da Ficha Cadastral dos candidatos no Sistema de Cadastro de Alunos do Estado, com especial atenção para as informações relativas ao endereço completo, tendo em vista o encaminhamento de correspondência.

06 a 29/10/2009 - Compatibilização entre demanda e vagas existentes, incluindo propostas específicas para o atendimento nas áreas/escolas congestionadas, com responsabilidade compartilhada entre Estado e Município.

13/10 a 10/11/2009 - Digitação da matrícula, no Sistema de Cadastro de Alunos, dos candidatos ao ingresso no ensino fundamental, definidos na fase I e dos cadastrados nas fases II e III, nas escolas estaduais e municipais. 
A partir de 16/11/2009 - Competia à escola de origem a divulgação do resultado da matrícula dos alunos definidos na fase I e dos cadastrados nas fases II e III, mediante afixação de listas com a relação nominal dos alunos, nas escolas estaduais e municipais. Para cadastrados nas fases II e III foi enviada correspondência conjunta Estado/Município, endereçada aos pais ou responsável, emitida pela Secretaria de Estado da Educação, centralizadamente.

20/10 a 23/11/2009 - Cadastramento e digitação, no Sistema de Cadastro de Alunos do Estado, dos candidatos à vaga no ensino fundamental, inclusive na modalidade de educação de jovens e adultos, que não se cadastraram nas fases II e III, nos prazos previstos para o processo.

A partir de 23/11/2009 - Digitação das matrículas, para o ano letivo de 2010, dos alunos das demais séries/anos do ensino fundamental em continuidade de estudos, inclusive na modalidade de educação de jovens e adultos.

24/11 a 04/12/2009 - Compatibilização dos cadastrados após o prazo das fases II e III.

07 a 11//12/2009 - Digitação, no Sistema de Cadastro de Alunos do Estado, das matrículas solicitadas após o prazo estabelecido nas fases II e III, em todas as séries do ensino fundamental, inclusive na modalidade de educação de jovens e adultos, para o ano letivo de 2010. Foi de competência da escola de cadastramento a divulgação do resultado das matrículas, mediante afixação de listas com a relação nominal dos alunos, nas escolas estaduais e municipais.

01 a 22/12/2009 - Digitação do rendimento escolar individualizado, de todos os alunos das escolas estaduais, no Sistema de Cadastro de Alunos.

11/01/2010 - Prazo final para as escolas estaduais concluírem a digitação das matrículas de seus alunos em continuidade de estudos, para o ano letivo de 2010.

A partir de 12/01/10 - Inscrição/Cadastramento dos candidatos à vaga, na rede pública, que perderam os prazos previstos de inscrição pelo Programa da Matrícula Antecipada 2010, executado no último trimestre de 2009. No cadastramento desses candidatos não deveriam ser incluídos aqueles caracterizados como solicitações de transferência de escola, ou seja, aluno com matrícula em 2010, sendo vedada a exclusão de aluno já matriculado. Para esse caso foi utilizada exclusivamente a opção específica do Sistema para essa finalidade, disponibilizada em 2010. 
Após o início das aulas - a compatibilização dos candidatos inscritos nas escolas estaduais e municipais ocorreu sempre que houve demanda a ser atendida, independente do número de candidatos cadastrados, com digitação imediata da matrícula no Sistema de Cadastro de Alunos do Estado, pelos órgãos regionais, e divulgação sob responsabilidade da escola de cadastramento.

Todo o cadastro era definido no sistema do estado, tornando desnecessária a utilização de outros sistemas pelos municípios. No entanto, diversos municípios possuíam sistemas próprios para gerenciamento das escolas municipais, o que era o caso do município de São Paulo. Na capital, as definições de classes, turmas e matrículas foram inicialmente realizadas no sistema municipal de matrículas e gerenciamento escolar. Durante o período de matrículas, estas eram enviadas para o sistema estadual através de troca não sincronizada de arquivos, que eram gerados no sistema municipal e inseridos no sistema estadual. Esta troca de arquivos era realizada de forma manual, o que acabou acarretando em erro na matrícula de diversos estudantes.

Para deixar mais claro, o processo de matrícula possuía o seguinte fluxo no sistema da prefeitura de São Paulo:

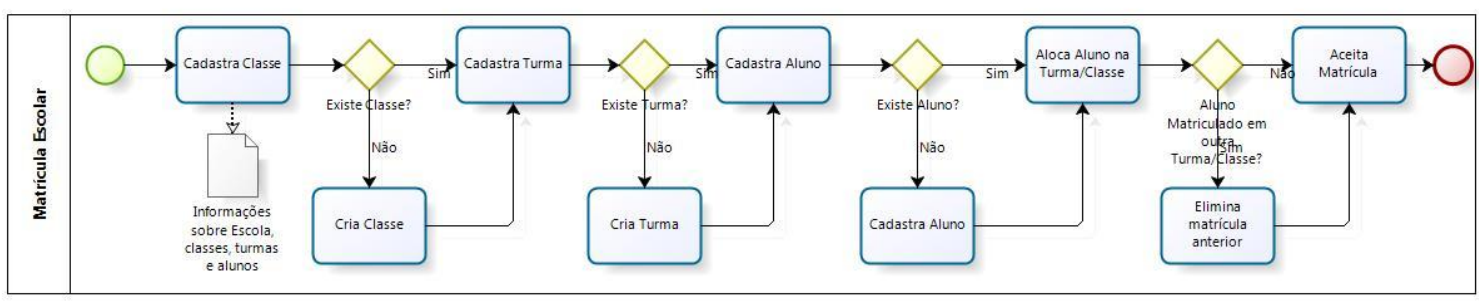

Figura 2: Processo de matrícula escolar.

O processo de matrícula antecipada era realizado nas seguintes etapas:

1. A Prodam enviava, antes da matrícula antecipada, um arquivo para a Prodesp inserir os dados de classes e turmas no sistema do estado;

2. Com as classes e turmas criadas era enviado um segundo arquivo, com os alunos já cadastrados para serem alocados nas turmas e classes existentes; A Prodesp enviava um arquivo de retorno, informando erros no cadastramento. Uma vez verificados os erros, era gerado novo arquivo que era enviado para a Prodesp 
3. Novos alunos eram primeiro cadastrados no sistema do estado, sendo que uma vez validados eram cadastrados no sistema da prefeitura e a matrícula era efetivada no município;

4. Após, era enviado novo arquivo, com os dados dos novos alunos cadastrados.

O problema aconteceu nesta última etapa. Como os alunos podiam ser cadastrados no sistema do município sem estarem cadastrados no sistema do estado, muitas escolas realizavam a matrícula antes de conferir se o aluno podia ser regularmente matriculado. Com isso um dos arquivos enviados gerou erro, mas a falha não foi verificada e todos os alunos cujos dados estavam neste arquivo tiveram suas matrículas ignoradas, segundo o que foi apurado nas entrevistas. Assim, a falha do processo recaiu sobre o sistema.

\subsubsection{A origem da interoperabilidade como solução para o processo de matrículas no Estado}

A interoperabilidade entre os sistemas de matrícula do Estado e do Município de São Paulo é a evolução de uma série de fatos que, somados, resultaram em uma das primeiras integrações entre Estado e município nas áreas sociais. "Para mim o processo iniciou em 2007, quando assumi a Corregedoria Geral da Administração do Estado", conta o Corregedor Geral à época.

Em 2007, a Corregedoria possuía centenas de diligências a finalizar e o número de corregedores era reduzido. O corregedor resolveu rever os processos de trabalho e, durante esta empreitada, ficou claro que o principal problema era a dificuldade de cruzar as informações dos diferentes sistemas disponíveis no Estado (que, no caso de compras governamentais, chegavam a doze).

Ao apresentar a questão para o Secretário da Casa Civil (secretaria à qual a Corregedoria é vinculada no Estado de São Paulo) este "tomou as dores" da Corregedoria e buscou um acordo com o Secretário de Gestão Pública, pois o gerenciamento de sistemas do Estado estava (e, com poucas exceções, ainda está) incluído nas obrigações dessa secretaria. Chegaram a um acordo e publicaram a resolução conjunta CC/SGP/PGE-1 no 67 de 09 de abril de 2007, que incumbiu a Corregedoria Geral da Administração de "colher informações, analisar e propor, em 90 dias, medidas para o aperfeiçoamento dos sistemas 
gerenciais e de tratamento de informações da Administração Pública Estadual” (CGU, 2007).

Em um primeiro momento, o corregedor desejava construir um grande ERP, um sistema que substituísse os atuais sistemas por outro mais moderno e que abraçasse todos os processos necessários. Chamou o sistema de SECI: Sistema Estadual de Controle Interno, mas não sabia como integrar esse sistema aos sistemas proprietários do Estado.

A partir da publicação da resolução, a Corregedoria, junto com o Grupo Gestor de Tecnologia da Informação da Secretaria de Gestão Pública, organizou um encontro entre os principais dirigentes da área de tecnologia do Estado a fim de debaterem soluções para o problema da integração de sistemas do Estado. No encontro, cada representante de sistema defendia a supremacia do seu próprio sistema para, com novos investimentos, substituir os outros, corroborando o já afirmado por Arcieri ET AL. (2002), de que na área pública faltava coordenação de trabalho entre as áreas, o que dificultava qualquer integração.

Após o encontro, o corregedor já percebera que não seria possível trabalhar com a ideia de um sistema único, mas não encontrava solução para o problema. Passados os 90 dias estipulados pela resolução, o corregedor ainda não compreendia plenamente o problema enfrentado, nem conseguira definir a solução. O prazo foi sendo prorrogado até 2008 e o corregedor já considerava a possibilidade de abandonar o projeto. "Foi quando tive uma reunião com um especialista, então professor da FGV (e Superintendente na FDTE), que me apresentou a solução baseada na interoperabilidade entre os sistemas estaduais", afirma o corregedor. O Superintendente comenta, em sua entrevista: "uma vez o Michel (Michael Paul Zeitlin, ex-Secretário dos Transportes e ex-Diretor da EAESP-FGV) conversando com o Corregedor quando assumiu a corregedoria, na conversa o Michel falou 'eu sei quem pode te ajudar'. Então foi ele quem fez a ligação, eu tive alguns contatos com o Corregedor, expus as ideias antes de qualquer concretização e ele gostou das ideias".

A partir desse encontro, o corregedor apresentou à Casa Civil um relatório, expondo a necessidade de interoperabilidade dos sistemas para viabilizar a construção de um sistema de correição eficaz. O projeto foi aprovado, mas o corregedor não possuía força política suficiente para desenvolver e implantar o projeto: "eu possuía o apoio do Secretário da Casa Civil e do Beraldo (Secretário de Gestão Pública), mas precisava de mais apoio para 
viabilizar o projeto". Em março, começou a apresentar o projeto para toda autoridade que o visitava. Em junho, chegou a solicitar uma proposta comercial por parte do Superintendente, mas a FGV passava por um processo turbulento na época, o que dificultava a contratação.

Em paralelo, o Centro de Estudos e Pesquisas em Administração Municipal - Cepam, fundação Estadual vinculada à Secretaria de Planejamento e Desenvolvimento Regional, passava por grandes mudanças estruturais, retomando seu papel histórico de interlocutor do Estado junto aos municípios. Também conhecido pelo nome que recebeu em 1976, Fundação Prefeito Faria Lima, o Cepam tem como missão "Fortalecer os municípios, desenvolvendo a gestão e as políticas públicas" (CEPAM, 2008). Em 2008, em consequência de inovações na forma de contratar serviços de impressão coorporativa para o Cepam, seu gerente de informática era convocado constantemente para prestar explicações na corregedoria. Em março de 2008, ele almoçou com o corregedor, que expôs o problema que estava tendo para avançar com o projeto de integração. O gerente sugeriu que o Cepam poderia auxiliar, desde que também fosse analisada a possibilidade de interoperar com os sistemas municipais. O corregedor se interessou e foi agendado um encontro dele com o Presidente do Cepam.

"Quando o Cepam foi chamado para trabalhar com a Corregedoria no desenvolvimento do modelo para o Estado, ressaltei que era necessário acrescentar a interoperabilidade com os municípios, ou não teria projeto", conta o Presidente. O Corregedor não via problemas nesta solução, principalmente porque o apoio do Cepam reforçava politicamente o projeto, aproximando a Secretaria de Planejamento. Criavam-se, assim, condições políticas para a implantação, premissa para que um projeto de interoperabilidade acontecesse (SANTOS, 2002). Em 03 de dezembro de 2008 a Corregedoria e o Cepam assinavam o contrato para dar início aos trabalhos que levariam à criação do modelo de interoperabilidade.

\subsubsection{Interoperabilidade na educação: uma união de fatores}

A decisão de trabalhar com os sistemas da educação para gerar a interoperabilidade não era uma opção do início do projeto. O Corregedor lembrou que: "em uma segunda reunião acordamos a importância de também tratarmos alguma área fim de governo, pois, para os municípios, estas eram mais relevantes. Ficamos entre educação, assistência 
social e saúde, sendo que acabamos escolhendo a primeira por possuir sistemas melhor estabelecidos e com uma maior relevância do Estado no processo do que nas outras áreas, onde a maioria dos sistemas era federal". Assim, a educação passou a ser estudada por uma questão puramente acessória. Isto ficou claro no desenvolvimento dos trabalhos, pois a interoperabilidade na educação só foi estudada a partir do oitavo mês de trabalho do grupo, em um projeto previsto para ser finalizado após um ano.

O oitavo relatório do desenvolvimento do modelo para interoperabilidade de sistemas no Estado (FDTE, 2009) informa que, em 06 de outubro de 2009, ocorreu a primeira reunião na Secretaria de Educação do Estado de São Paulo, na Praça da República - Colégio Caetano de Campos, inicialmente agendada apenas com o Chefe de Gabinete da Secretaria de Educação do Estado de São Paulo. Na reunião foi apresentado o Projeto Gestão Integrada, que foi muito bem recebido e a proposta do piloto foi aceita pela Secretaria. O Chefe de Gabinete comentou que a Secretaria já estava procurando uma solução para a conectividade com os municípios e que a proposta de interoperabilidade foi a primeira solução factível apresentada. Quem estava conduzindo o processo de integração de sistemas era a diretora do Centro de Informações da Educação (CIE), que foi chamada para a reunião. O projeto foi novamente apresentado e, em contrapartida foram apresentados os sistemas de informação para o gerenciamento de matrículas, escolas, classes e professores. A Diretora do CIE ficou interessada em conduzir o piloto, solicitando que agendássemos nova reunião com os técnicos para detalhar os sistemas e as possibilidades de integração. Foi agendada nova reunião para a semana seguinte e, em 16 de outubro de 2009, foi realizada uma reunião em que foram apresentadas as principais funcionalidades do Sistema de Cadastro de Alunos.

Estavam presentes integrantes da equipe do Cepam que analisava os sistemas passíveis de serem interoperáveis no Estado. Pela secretaria participaram a Diretora do CIE e o responsável pelo controle de matrículas. Na reunião ficou claro o desconforto da equipe da Secretaria com a questão. A diretora constantemente questionava o fato dos sistemas dos municípios terem acesso direto ao sistema estadual. Em sua visão, o sistema seria prejudicado e dados poderiam ser perdidos com esse acesso direto. $\mathrm{O}$ trabalho maior da equipe do Cepam foi convencer os interlocutores da Secretaria de que a interoperabilidade não acarretaria problemas para o Estado, e sim uma melhoria significativa para os municípios. A equipe da secretaria continuou com dificuldade em aceitar que a interoperação entre sistemas seria positiva; no entanto, meses depois o 
Cepam seria procurado para avançar com o projeto, em razão de um problema relacionado às matrículas que afetou a imagem do município e do Estado.

\subsubsection{A influência da opinião pública}

"Quando recebi a ligação do Sinval no meu gabinete, já sabia que tinha um pepino enorme para apresentar ao prefeito. Chamei os técnicos e discutimos sobre a origem do problema, ficando claro que era por falha de comunicação com o Estado, um problema operacional. Fui para a reunião com o prefeito sabendo que teríamos que brigar com o Estado, mas esta não era uma opção". É desta forma que o Ex-secretário de Educação do município relatou sua reação após saber da existência de uma reportagem que iria ao ar na TV Globo sobre os problemas na realização de matrículas escolares enfrentados pelos paulistanos.

O Secretário ficou sabendo a respeito da reportagem após receber uma ligação da TV, pedindo que se posicionasse sobre o tema. Como era de praxe nessas situações, o Secretário de Comunicação da Prefeitura foi chamado para avaliar a repercussão da notícia. Ao chamar os técnicos da Secretaria, ficou claro que o problema era muito maior: havia uma disparidade de cerca de 40.000 alunos entre o sistema municipal de matrículas e o sistema estadual; estes alunos não foram matriculados corretamente, pois o sistema do Estado informava que os dados eram incongruentes ou conflitantes. A solução para a questão operacional seria mudar a forma de trocar informações com o Estado, o que exigia uma conversa do Prefeito com o Governador, não bastando apenas a conversa entre os secretários.

"Nessa mesma tarde fomos até o gabinete e o Kassab já me pôs contra a parede. Expliquei o problema e ele ligou para o Serra, marcando para o dia seguinte um encontro, junto com os Secretários. É que com a repercussão não bastava apenas resolver o problema, precisávamos mostrar para a mídia que nós estávamos preocupados”. Para a reunião foram convocados também os presidentes da Prodesp e da Prodam, o que permitiu que houvesse o comprometimento de todos desde o início.

Nessa reunião foi firmado o compromisso de integração dos sistemas. A Prodesp ficou responsável por coordenar os trabalhos e definir a solução tecnológica a ser adotada; a Prodam faria as adaptações necessárias ao EOL para a troca de dados e as equipes das 
Secretarias de Educação do Estado e do Município dariam o suporte necessário para a efetivação do processo. No dia seguinte foi realizada uma reunião dos Secretários com as equipes técnicas das duas secretarias, para apresentar a decisão sobre como seriam conduzidos os trabalhos. Ficou agendada uma reunião técnica para o mês seguinte, quando a Prodesp apresentaria um modelo de implantação do processo. A questão política estava resolvida e restava então definir tecnicamente como seria o processo de integração.

\subsubsection{O problema das matrículas no município de São Paulo}

No Estado de São Paulo, em média 3,9\% das crianças estão fora da escola. A tabela abaixo apresenta a evolução da taxa de frequência escolar de 2004 a 2009:

Tabela 11: Evolução da taxa de frequência líquida a estabelecimento de ensino das pessoas de 7 a 14 anos (Ensino Fundamental)

\begin{tabular}{|l|l|l|l|l|l|l|c|}
\hline Região & 2004 & 2005 & 2006 & 2007 & 2008 & 2009 & Média \\
\hline Estado de São Paulo & 96,3 & 96,9 & 97,1 & 96,3 & 96,6 & 93,4 & 96,10 \\
\hline Região Metropolitana de São Paulo & 96,2 & 97,3 & 97,4 & 95,9 & 96,6 & 92,5 & 95,98 \\
\hline
\end{tabular}

Fonte: Secretaria Estadual de Educação, 2010

Na tabela, percebe-se a significativa queda das taxas de frequência em 2009. Isso se deve ao fato de que, neste ano, as crianças com seis anos que iriam completar sete durante o ano, passaram a ser matriculadas na rede pública, aumentando o contingente de crianças e, consequentemente, o número de crianças fora da escola. O problema foi sanado aos poucos, mas a questão da matrícula das crianças com sete anos incompletos persiste até hoje. Um dos motivos, citados pelos técnicos da Secretaria do Estado é o fato do município definir datas de corte diferentes do Estado. Em 2011, as crianças que aniversariavam até 31/03 eram matriculadas na rede municipal, mas em Campinas a data era 30/06. Em razão disso, uma criança transferida de Campinas para São Paulo tinha problemas para ser matriculada na rede municipal, acabando por ser encaminhada para uma escola Estadual. Isso prejudicou muito o processo de matrícula em 2009, mas não foi o que causou o problema em 2010.

Em 2010 houve uma queda de 71.895 crianças matriculadas. Parte se deveu à queda do número de crianças no município, mas parte aconteceu pelas mudanças no critério de aceitação de crianças com sete anos incompletos e pela falha nas informações necessárias 
para a efetivação das matrículas. As crianças acabaram sendo matriculadas, mas no sistema constava uma diferença de 45 mil alunos que deveriam estar matriculados, mas que não constavam no sistema. O problema só foi corrigido em maio de 2010.

A origem do problema foi a forma como as matrículas eram atualizadas. O município de São Paulo possui 5.643 estabelecimentos de ensino de educação básica, sendo 1.760 da rede municipal. Cada estabelecimento da rede possui duas pessoas, ao menos, responsáveis por registrar as matrículas nos sistemas estadual e municipal, ou seja, 3.520 funcionários. Na tabela a seguir apresentamos as matrículas no município de São Paulo de 2008 a 2010, mostrando o salto no número de matrículas em 2009:

Tabela 12: Matrículas de 2008 a 2010 da Rede Municipal de Ensino no Município de São Paulo por tipo de estabelecimento.

\begin{tabular}{|c|c|c|c|}
\hline Tipo de Escola & 2008 & 2009 & 2010 \\
\hline Rede Municipal de Ensino & 953.967 & 1.016 .251 & 980.303 \\
\hline $\begin{array}{l}\text { Centro de Convivência Infantil/Centro Infantil de Proteção à } \\
\text { Saúde (CCI/CIPS) }\end{array}$ & 438 & 546 & 416 \\
\hline Centro de Educação e Cultura Indígena (CECI) & 308 & 340 & 322 \\
\hline Centro de Educação Infantil Conveniado (Rede Indireta) & 35.609 & 43.961 & 44.119 \\
\hline Centro de Educação Infantil Municipal (Creche da Rede Direta) & 35.818 & 40.070 & 37.865 \\
\hline $\begin{array}{l}\text { Centro de Educação Infantil no Centro Educacional Unificado } \\
\text { (CEU/CEI) }\end{array}$ & 6.203 & 10.520 & 10.188 \\
\hline Centro Integrado de Educação de Jovens e Adultos (CIEJA) & 8.050 & 9.118 & 11.185 \\
\hline Centro Municipal de Capacitação e Treinamento (CMCT) & 0 & 893 & 511 \\
\hline Creche Particular Conveniada & 52.921 & 78.382 & 79.510 \\
\hline Escola Municipal de Educação Especial (EMEE) & 1.316 & 1.433 & 1.361 \\
\hline Escola Municipal de Educação Infantil (EMEI) & 225.402 & 231.326 & 210.772 \\
\hline $\begin{array}{l}\text { Escola Municipal de Educação Infantil no Centro Educacional } \\
\text { Unificado (CEU/EMEI) }\end{array}$ & 16.392 & 26.028 & 26.125 \\
\hline Escola Municipal de Ensino Fundamental (EMEF) & 530.062 & 512.283 & 496.672 \\
\hline Escola Municipal de Ensinos Fundamental e Médio (EMEFM) & 11.977 & 11.244 & 11.370 \\
\hline $\begin{array}{l}\text { Escola Municipal de Ensino Fundamental no Centro Educacional } \\
\text { Unificado (CEU/EMEF) }\end{array}$ & 29.471 & 50.107 & 49.887 \\
\hline Total & 1.909 .942 & 2.034 .511 & 1.962 .616 \\
\hline
\end{tabular}

Nas escolas municipais há o EOL, mas este não se comunicava com o JCA, o sistema do Estado. As novas matrículas eram inseridas manualmente nas escolas nos dois sistemas, o 
que acarretava diversos erros. Além disso, os critérios díspares para a matrícula geravam incongruências, tais como crianças que eram impedidas de se matricular nas escolas municipais, mas que podiam fazê-lo nas escolas estaduais. Além das matrículas regulares, os alunos que já se encontravam matriculados na rede e que permaneciam nas respectivas escolas eram matriculados antecipadamente, em um processo à parte. "Na verdade, já havia uma troca de informações na matrícula antecipada desde 2006, quando a Prodesp recebia um arquivo da Prodam e inseria as informações no sistema, verificando as inconsistências" - relata o Diretor de atendimento da Prodesp. Na época, o arquivo era trabalhado para compatibilizar as informações, que eram inseridas individualmente por um Robot no sistema do Estado. As inconsistências eram assinaladas e o arquivo devolvido para a Prodam, que realizava as modificações. Foi nesse processo de leitura e troca de arquivos que as equipes deixaram de verificar um lote de crianças que foram consideradas matriculadas pelo município, porém não foram assimiladas pelo Estado, ou seja, foi um erro de procedimento. Ambos os sistemas funcionavam bem, mas a troca manual de informações acarretou o erro.

\subsubsection{A busca de uma solução integrada}

Com a ordem superior para resolver o problema, não havia mais como ignorar a verdadeira questão: se para os técnicos do Estado o JCA e todos os sistemas integrantes do GDAE eram suficientes para gerenciar a educação tanto do Estado quanto dos municípios e escolas particulares, para os municípios e para as escolas particulares isso não era uma verdade. O EOL organizava informações estratégicas para o município na educação, além de poder ser integrado com outros cadastros municipais, o que não acontecia com o JCA e os outros sistemas disponíveis no GDAE. A solução para os técnicos estaduais era, naturalmente, excluir o EOL, ou ignorá-lo, como vinham fazendo há anos. Porém, essa não era mais uma opção, havia a necessidade de construir uma ponte entre os sistemas.

\subsubsection{A opção pela Interoperabilidade}

Enquanto não acontecia a reunião para definir a forma como seria realizada a troca de informações entre os sistemas, a equipe da Prodesp pensava na solução técnica. A 
integração das bases foi descartada logo de início por três questões básicas: os sistemas eram desenvolvidos em plataformas diferentes (Natural com base de dados Adabas para o JCA e .Net com base SQL Server para o EOL); as regras de matrícula eram diferentes (regras de negócio dispares), tal como a data limite para as crianças que completam 7 anos durante o ano letivo; e a forma como os dados eram salvos, como o uso de acentuação no município e o não uso no sistema do Estado.

Segundo o Superintendente "o Estado já trabalhava com interoperabilidade desde 2003, quando desenvolvemos um trabalho para a Secretaria de Transportes. No município, em 1999, realizamos um trabalho para interoperação de dados para a Secretaria Municipal de Saúde, mas acabou não indo para frente". A análise técnica apontava para a interoperabilidade entre os dois sistemas, suplantando as dificuldades da equipe do Estado em "abrir mão" da exclusividade e do isolamento do sistema.

Uma ação aplicável de imediato era ter uma estrutura de metadados comum para compartilhar as informações, pois este estudo já fora realizado para viabilizar a troca de arquivos manual. A partir da definiçãa de metadados, a Prodesp elaborou um modelo de integração que apresentou em uma reunião conjunta das Secretarias. O Diretor da Prodesp relatou que "a Prodesp já possuía amplo conhecimento em interoperabilidade, mas principalmente entre sistemas internos do Estado". A experiência de integração com o município abria novas possibilidades para o Estado, que se preparava para disponibilizar em um site os dados abertos de governo. "Antes da reunião avaliamos de que forma poderíamos interoperar os sistemas com o menor custo possível. Decidimos por construir uma plataforma de integração que serviria para que outros municípios também se integrassem com o Estado facilmente, porém a integração com o JCA, para minimizar investimentos, foi realizada por meio de um gateway de integração, que simulava um operador do sistema". O simulador de operador (robot) já era utilizado para inserir as informações da matrícula antecipada, o que simplificava muito o desenvolvimento.

Assim, após um mês de estudos, a Prodesp já tinha como apresentar uma solução para o problema. A equipe que desenvolvia o modelo de interoperabilidade para o Estado também estava presente à reunião, para garantir que a solução adotada estaria aderente ao modelo proposto.

No projeto apresentado, o EOL se comunica por Web Service com uma camada de integração que armazena o dado e o encaminha para um Robot (gateway) que simula a 
operação no sistema JCA por um terminal 3270. O JCA retorna com instruções para o gateway e a camada de integração e, novamente por web service, a informação é retornada para o terminal do EOL.

Na reunião foi apresentado o seguinte modelo de troca de dados entre os sistemas:

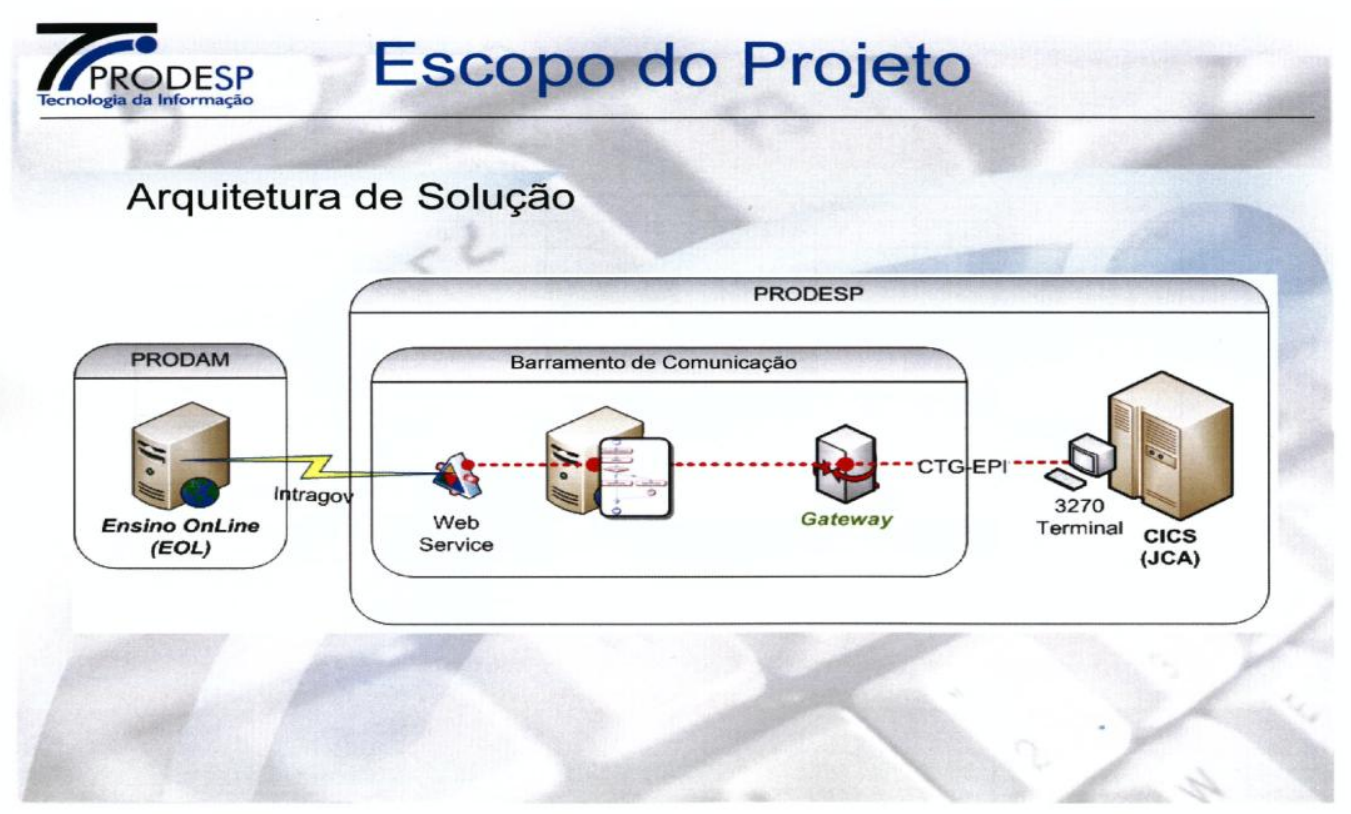

Figura 3: Esquema de comunicação entre EOL e JCA

Fonte: Prodesp, 2010

"Fora do período de rematrícula o sistema funciona bem, porém no auge da matrícula e da rematrícula o sistema apresenta diversas falhas e desempenho reduzido", relatou o Assessor técnico municipal na entrevista.

Para entender melhor o que acontece é preciso conhecer como são os sistemas envolvidos, bem como mais detalhes do modelo de integração, apresentados a seguir.

\subsubsection{O Sistema de Matrículas do Estado de São Paulo - JCA}

O Sistema de Cadastro de Alunos do Estado de São Paulo foi instituído pelo Decreto $N^{o}$ 40.290, de 31 de agosto de 1995 e desenvolvido pela Prodesp para a Secretaria de Educação do Estado de São Paulo. Permite o cadastro e identificação de todos os alunos da Educação Infantil, Ensino Fundamental e Ensino Médio de todas as escolas das redes 
de ensino do Estado de São Paulo; controla todas as turmas e tipos de ensino, bem como a movimentação das matrículas.

O JCA é um dos sistemas integrantes do GEDAE - Gestão Dinâmica da Administração Escolar, um portal voltado para a administração escolar e a coleta de informações gerenciais. Na página seguinte vemos a tela inicial do GDAE: 


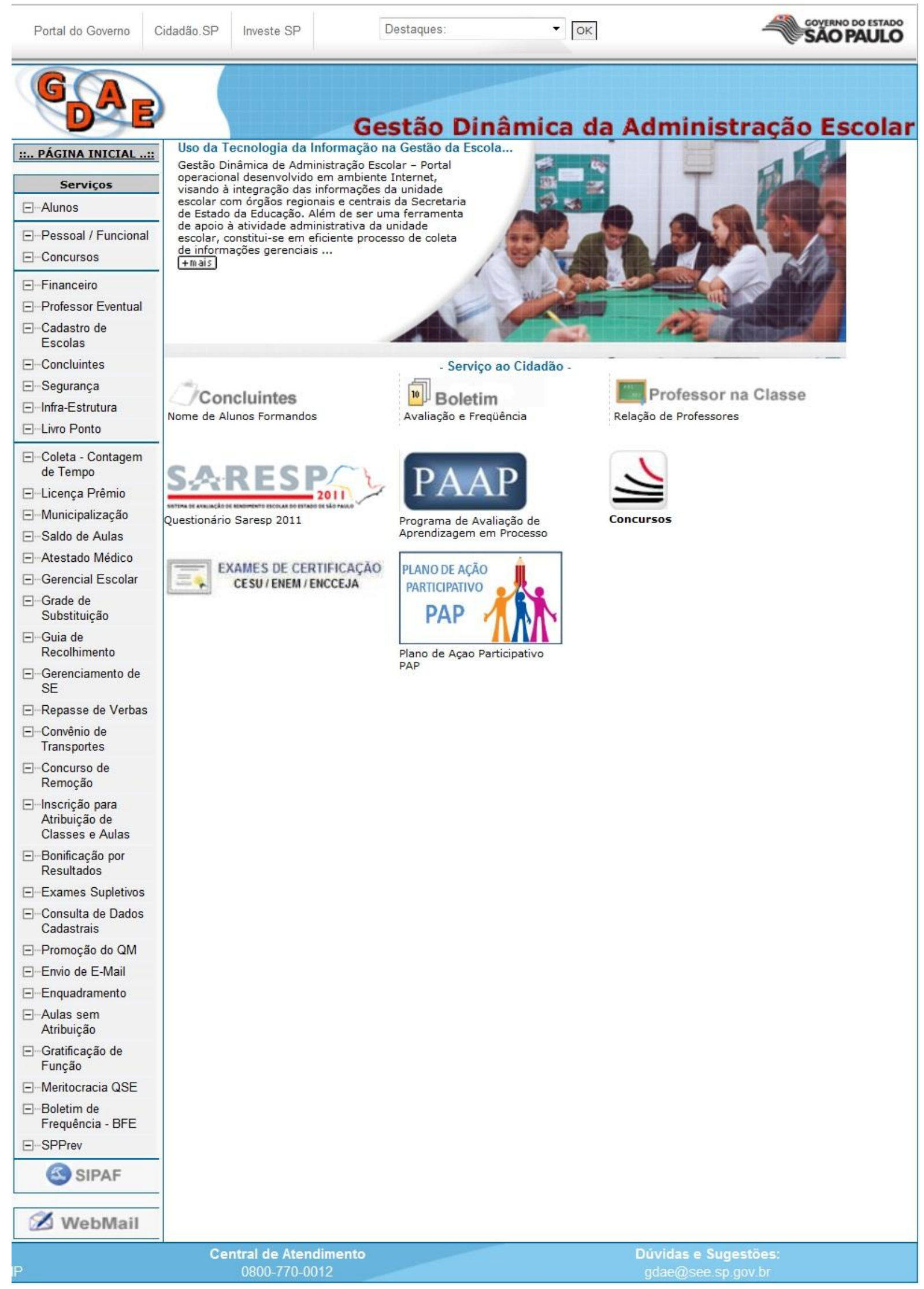

Figura 4: Tela de abertura do GDAE.

Fonte: http://www.gdae.sp.gov.br/gdae/PortalGdae/Default.jsp 
A legitimidade do uso do sistema é dada pela deliberação CEE $n^{\circ}$ 02/00, que dispõe sobre o cadastramento geral dos alunos de educação básica no sistema de ensino do Estado de São Paulo, pela resolução SE N. ${ }^{\circ}$ 12, de 8 de fevereiro de 2007, que institui o Sistema de Cadastro de Alunos do Estado de São Paulo como instrumento de coleta de dados do Censo Escolar e pela Resolução SE 20, de 17-2-2010, que atribui responsabilidades pelas informações lançadas nos Sistemas de Informação Corporativos da Secretaria de Estado da Educação. Além do cadastro, o sistema registra a alocação de classe para o aluno, originando a matrícula escolar.

Para acessar o JCA é necessário primeiro se registrar via GDAE, entrar no programa emulador de terminal e realizar nova identificação de usuário. Não são todos os estabelecimentos de ensino que possuem acesso, apenas as Secretarias Municipais e Estadual de Educação, as Diretorias de Ensino, as escolas públicas e algumas redes particulares. O usuário precisa estar previamente cadastrado e após passar por diversas telas de acesso e registro é apresentada a tela inicial do JCA:

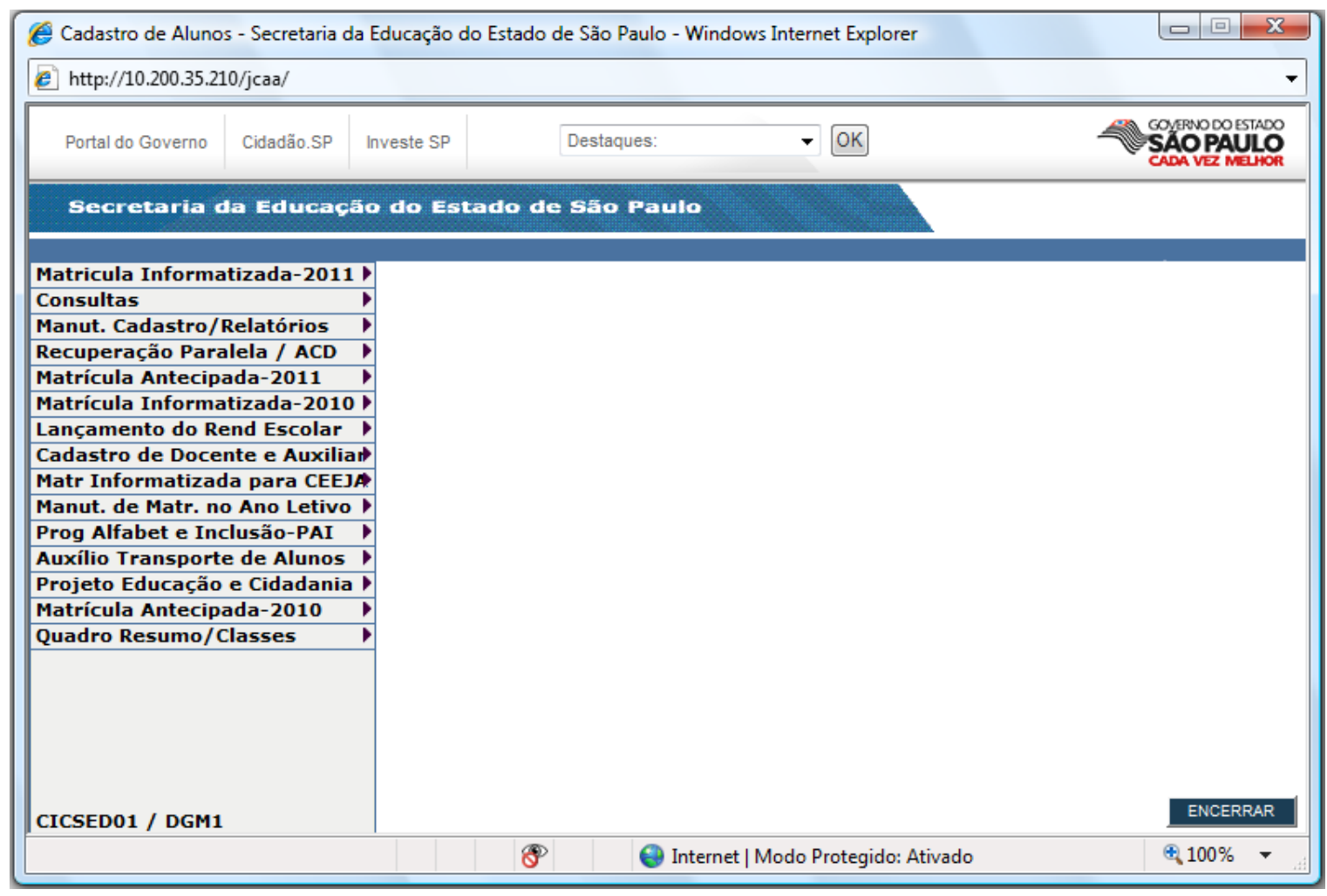

Figura 5: Tela inicial do JCA.

Fonte: SEE, 2010 
O modelo do sistema é cliente servidor, sendo que, para facilitar o acesso às escolas particulares, o terminal é simulado em qualquer PC com acesso à Internet.

Os estabelecimentos que não possuem acesso ao sistema devem se dirigir a uma escola pública ou qualquer outro local com acesso e solicitar a inclusão dos dados dos alunos e respectivas matrículas no sistema. No cadastro do aluno e de suas informações particulares não é permitido o uso de acentuação, para compatibilização com o sistema federal. Isso gera problemas para os municípios, cujos sistemas já utilizam acentuação para identificar os alunos, no retorno de informações, pois existem casos de homônimos decorrentes da falta de acentuação. Esse é um dos motivos que leva à necessidade de intervenção humana no cadastro dentro do sistema, pois a identificação automática gera erros. Uma vez o aluno cadastrado, os erros são minimizados.

\subsubsection{Estrutura do Sistema JCA}

O sistema é composto por diversos módulos, sendo os principais:

Cadastro e Manutenção dos Dados do Aluno: inclusão, alteração dos dados de identificação do Aluno (nome, filiação, endereço, documentação, etc.).

Cadastro e Manutenção das Turmas da Escola: cadastro das turmas da escola identificando período, tipo de ensino, série, habilitação, sala, etc. e registro dos alunos em cada turma.

Manutenção das Matrículas: registro dos eventos de Transferência, Abandono, Não Comparecimento e Reclassificação das matrículas dos alunos.

Manutenção do Cadastro de Docentes / Disciplinas / Turmas: inclusão, alteração dos dados de identificação do Docente (nome, filiação, documentação, formação, etc.); cadastro das Disciplinas de cada turma e registros dos Docentes de cada disciplina da turma.

Controle do Transporte Escolar: identificação dos alunos transportados, do tipo de transporte, distância e provedor.

Matricula Informatizada para CEES: módulo para o controle e manutenção da situação dos alunos matriculados nos Centros de Ensino Supletivo. 
Programa de Alfabetização e Inclusão - PAI: o objetivo do programa é atender a jovens e adultos, a partir de 15 anos de idade, que não tiveram acesso à escolarização formal na idade própria. O módulo propicia o cadastro das turmas e seus respectivos alunos, bem como a manutenção da situação da matrícula de cada aluno.

Projeto Escola da Juventude: é uma alternativa de EJA (Ensino de Jovens e Adultos), voltada para jovens de 18 a 29 anos que estão fora da escola por não disporem de tempo para frequentar aulas durante os dias de semana. As atividades são oferecidas nos finais de semana, tendo como base o uso de materiais impressos e mídias digitais para apoiar o desenvolvimento da aprendizagem. Além disso, tem uma forte ênfase na inclusão digital. O módulo controla o cadastro das turmas e seus respectivos alunos, bem como faz a manutenção da situação das matrículas de cada aluno.

Projeto Educação e Cidadania: módulo que tem por objetivo cadastrar as turmas das Unidades de Internação Provisória e registrar os alunos que dão entrada nessas unidades/turma fazendo o acompanhamento de sua situação dentro da UIP.

Programa Segurança nas Escolas: registro das ocorrências da escola, detalhando as informações (classificadas por tipo, subtipo, local, existência ou não de BO, data do BO e identificação da delegacia de policia na qual foi lavrado); tipos de ocorrência: contra a pessoa (23 subtipos) e contra o patrimônio (14 subtipos).

\subsubsection{Benefícios}

O JCA, em conjunto com todos os sistemas disponibilizados no portal GDAE, proporciona à SEE uma ferramenta para o total controle sobre a demanda e a oferta da Educação Básica no Estado de São Paulo. Gera um único número do estudante, o RG Escolar, possuindo rotinas de consistências, que através de fonemas evitam a geração de mais de um RA por aluno. No caso de homônimos com mães homônimas, o sistema apresenta as inconsistências para serem sanadas manualmente, com o acréscimo de dados. O aluno, munido do RA, passa a ter identificação única no Estado. O número do RA pode ser transformado, no final da vida letiva, no RG do cidadão. Além disso, o sistema disponibiliza a obtenção de diversos relatórios e informações individualizadas:

1. Permite a localização de um aluno com uma simples consulta, atendendo a diversas solicitações do Poder Público com grande agilidade e precisão. 
2. Permite a obtenção dos dados da ficha do aluno de maneira instantânea por diferentes formas de acesso: por RA; por nome fonético; por nome completo; por escola; por número da classe; por nome do PA; por nome da mãe e por RG civil.

3. Disponibiliza consultas aos dados da turma de cada escola, desde 1995, informando os totais de cada turma, os alunos transferidos, as ausências, os abandonos, etc., permitindo a apresentação da lista de alunos da turma e acesso à ficha de cada um.

4. Apresenta uma visão da utilização da escola por ano letivo, tipo de ensino e turno, apresentando totais de turmas e alunos.

5. Permite a consulta do histórico de matrículas do aluno, desde 1995, de maneira instantânea, por diferentes formas de acesso: RA, nome fonético ou nome completo do aluno.

6. Disponibiliza consultas gerenciais da escola.

7. Consulta totais e respectivas percentagens de alunos por ano de nascimento/sexo/tipo de ensino/série.

8. Apresenta consulta da tabela de ocupação da escola de maneira on-line, com quantidade de alunos e identificação da turma que ocupa cada sala de aula em cada período.

Desta forma, o Estado de São Paulo passou a ter uma ferramenta gerencial de qualidade para suas escolas, diminuindo custos e melhorando o atendimento para a população. O sistema é estável, sendo que não estão sendo pensadas grandes alterações no médio prazo. No entanto, constantemente são realizados ajustes para adaptar o sistema às novas exigências do MEC e da Secretaria Estadual de Educação.

\subsubsection{Tecnologias utilizadas}

No desenvolvimento do JCA foi utilizada a arquitetura Cliente/Servidor. Para o acesso via Web é utilizado um emulador de terminal. O sistema operacional do servidor no qual se localizam os dados é o Z/OS. O sistema foi desenvolvido em linguagem Natural e utiliza o banco de dados Adabas. As regras aplicáveis a cada situação de matrícula estão 
embutidas na codificação da interface, sendo necessário um novo desenvolvimento da aplicação para a separação das regras. Isso dificulta o desenvolvimento de web services para a conexão direta com o banco, pois, sem passar pelas interfaces, as regras não são verificadas e os dados podem estar inconsistentes, não sendo possível a inserção por esse método. Entrevistei um especialista da Software AG que informou que é possível, com a atualização da versão dos softwares instalados na Prodesp para o desenvolvimento, separar as regras da camada de interface, permitindo uma verdadeira interoperabilidade do sistema.

\subsubsection{O EOL - Escola on-Line}

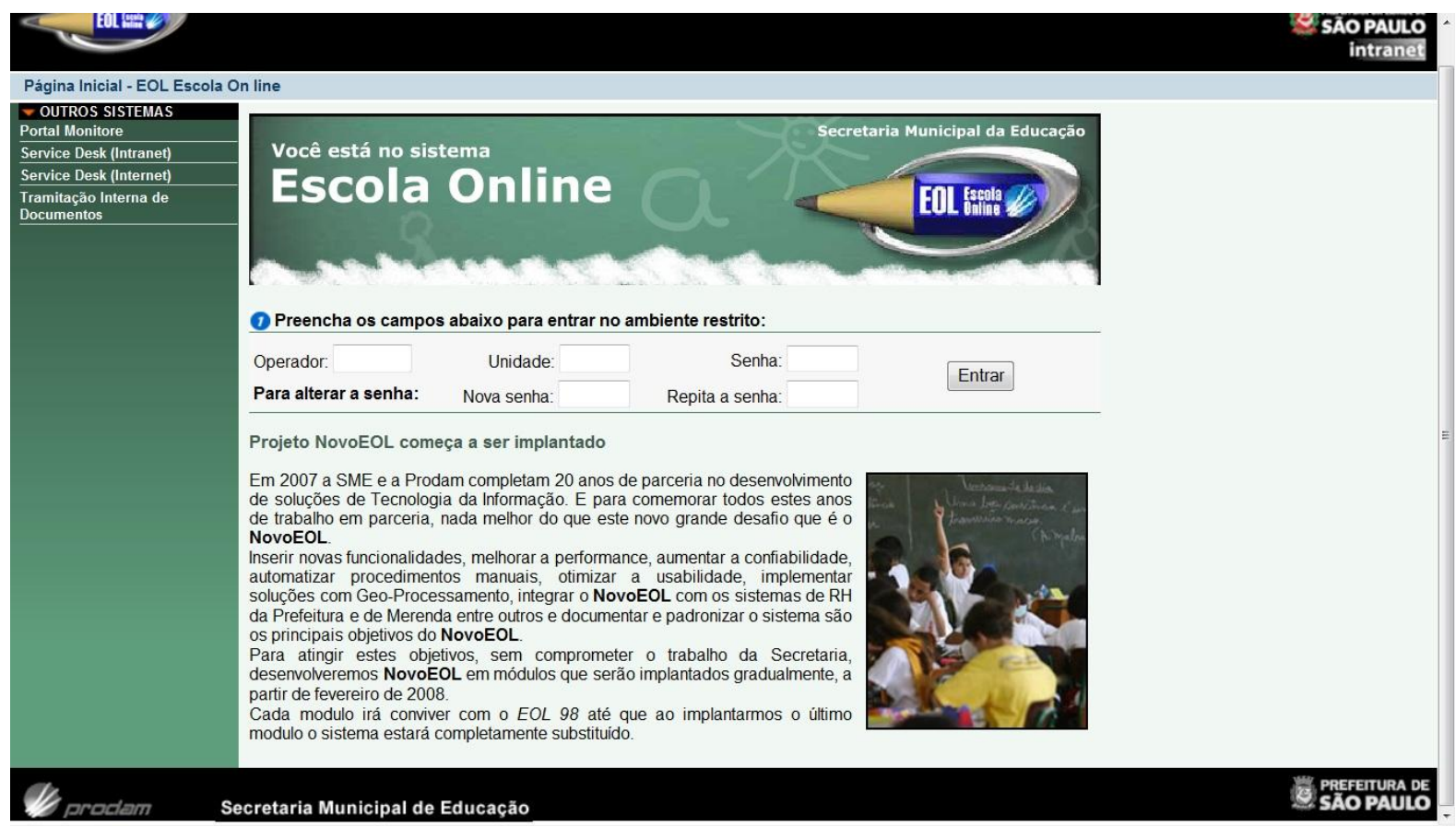

Figura 6: Página inicial do sistema Escola On line - EOL.

Fonte: http://eol.prefeitura.sp.gov.br/index.asp

Acima apresentamos a tela inicial do EOL - Escola On-Line, uma ferramenta de gestão escolar constituída por um conjunto integrado de informações e processos, destinada a apoiar a ação administrativa e a tomada de decisão nas escolas e órgãos administrativos da Secretaria Municipal de Educação de São Paulo. É formado por um conjunto integrado de sistemas e seu objetivo é suprir a secretaria, em tempo real, com informações significativas, de modo a apoiar a ação administrativa e a tomada de decisões tanto nas 
escolas quanto nas delegacias de ensino e órgãos da administração superior, bem como disponibilizar informações de interesse público.

O cenário de atuação do sistema EOL é constituído por mais de 850 escolas que oferecem educação infantil, ensino fundamental, ensino médio, ensino supletivo e educação especial; cerca de 50 mil servidores (professores, especialistas, administrativos e operacionais); cerca de um milhão de alunos e 13 DREMs - Diretorias Regionais de Educação. Foi desenvolvido pela Prodam para a SME e implantado em setembro de 1998. Segundo Whalter Araujo de Aquino "para diminuir a resistência dos diretores das escolas ao novo sistema os equipamentos de acesso foram instalados em 15 dias nas 824 escolas da época. Em cada escola duas pessoas foram capacitadas no uso do sistema e em seis meses todos já tinham condições de usar o sistema". "O êxito do sistema foi obtido na efetivação das matrículas de 1999, com o bloqueio de matrículas em duplicidade, consulta ao saldo de vagas, realização de reserva e efetivação de matrículas, tudo em tempo real" (ALMEIDA, 2000).

Em 2007, iniciou-se um processo de revisão tecnológica de todos os módulos do EOL. A instalação dos novos módulos se iniciou em 2008 e até 2013 todos os módulos do novo EOL devem estar instalados. O sistema é dinâmico e está em constante evolução.

\subsubsection{Estrutura do Sistema EOL}

As aplicações do EOL são acessadas pela Internet e sua base de dados está centralizada na Prodam - Cia. de Processamento de Dados do Município de São Paulo. As informações podem ser seletivamente acessadas (é definido perfil de usuário do sistema) a partir de qualquer ponto da rede.

O sistema é constituído pelos módulos Gerencial, Operacional, Administrativo e Público, que tratam as informações sob diversos agrupamentos e abrangências, com acesso a cada módulo definido de acordo com a identificação do usuário.

O módulo Gerencial disponibiliza consultas à informações da SME como um todo, por segmentações regionais e pesquisas por escola.

O módulo Administrativo tem recursos que permitem às DREMs operar no universo de informações das escolas a elas subordinadas. 
O módulo Operacional permite operação exclusiva com os dados de uma escola.

O módulo Público disponibiliza informações de interesse do cidadão.

\subsubsection{Benefícios}

Nos anos 2000 já era possível realizar matrículas on-line, bem como a colocação de alunos em lista de espera e controle de vagas, além de rematrículas, movimentação de alunos e emissão do Diário de Classe. O sistema também já permitia a inscrição no concurso de remoção e a concessão e controle das verbas de primeiro escalão. No módulo Gerencial já eram fornecidas as informações a nível geral da secretaria, por delegacia regional e por escola. No módulo público, a população podia realizar: reserva de matrículas; consultas às vagas nas escolas; localização de escolas municipais, estaduais e particulares no mapa da cidade; matrícula automática no $1^{\circ}$ ano do ensino fundamental dos alunos das escolas municipais de educação infantil (anualmente, aproximadamente 100 mil alunos), e visualizar o gerenciamento de recursos humanos (ficha cadastral e vida funcional, concursos de remoção e acompanhamento do processo de ingresso do servidor/professor) (ALMEIDA, 2000).

Segundo Almeida (2000) o EOL “proporciona segurança, simplificação e agilidade no tratamento das informações relacionadas aos processos administrativos da escola, informações em tempo real, aos diferentes níveis gerenciais da SME e, ao cidadão, informações como vagas disponíveis e localização de escolas no mapa do município".

Na Secretaria Municipal de Educação o sistema permite pesquisas em tempo real a partir de uma única base de dados. Houve redução do fluxo de papéis, constituído por grande volume de relatórios e formulários, memorandos e protocolos, que ocorre entre escolas, delegacias regionais e órgãos administrativos e a total eliminação dos processos de atribuição de aulas e de remoção de servidores, que passaram a ser informatizados. Uma melhoria significativa foi a possibilidade de saber com exatidão o número de alunos matriculados em menos de dois minutos, processo que antes levava três meses para ser realizado manualmente.

Com o processo de matrícula informatizado não havia mais a necessidade dos pais irem até a escola para a matrícula, além de existir a reserva de matrícula automática para o $1^{\circ}$ ano. No primeiro ano de funcionamento os pais ainda seguiam para as escolas para 
confirmar se os filhos estavam matriculados, pois não tinham confiança no sistema. A partir do segundo ano as filas diminuíram até deixarem de existir. "O processo de atribuição de aulas, que tinha a duração mínima de 20 dias, passou a ser realizado em cinco dias" (ALMEIDA, 2000).

O sistema bloqueia, no ato, a realização de reserva ou matrícula em duplicidade, permitindo o aproveitamento de apenas uma vaga por aluno e dimensionamento real da carência efetiva de vagas. Em qualquer ponto da rede pode ser pesquisado o número de vagas existentes e efetuada a reserva de matrícula. O cidadão só comparece à escola para confirmar a matrícula e apresentar a documentação.

\subsubsection{Tecnologias utilizadas}

Projetado para uso em plataforma baixa, o EOL foi desenvolvido em .NET, utilizando banco de dados SQL Server. Está instalado em um servidor Intel com Windows Server 2008, na Prodam. É acessado por meio de 30.000 computadores instalados nas escolas. Cada escola possui também um servidor Linux que concentra as bases locais e se comunica com a base central do EOL por Intranet ou Internet.

A Prodam também disponibiliza um Help Desk e treinamento para os técnicos das escolas para a manutenção local do sistema.

\subsubsection{A Interoperabilidade entre os Sistemas}

Para que a interoperação entre os sistemas ocorresse dentro do prazo acordado entre Governador e Prefeito (matrícula antecipada de 2011), foram aproveitadas as definições de metadados que já possibilitavam a geração dos arquivos para transmissão em lote das informações de matrícula entre as secretarias e definidos os grupos de informações que seriam trocados em tempo real. A figura 8 apresenta este fluxo, tanto das informações de banco de dados quanto das informações operacionais.

A geração da interoperabilidade entre os sistemas foi programada para ser realizada em fases, sendo que, na primeira fase, seriam trocadas as informações relativas a: dependências físicas da escola; coleta de classes; dados do aluno (com possibilidade de consulta em tempo real) e dados para matrícula antecipada. Na segunda fase seriam 
trocados os dados de novas matrículas (toda matrícula que não faz parte da matrícula antecipada).

A seguir é apresentado o fluxo de interoperação entre o EOL e o JCA:

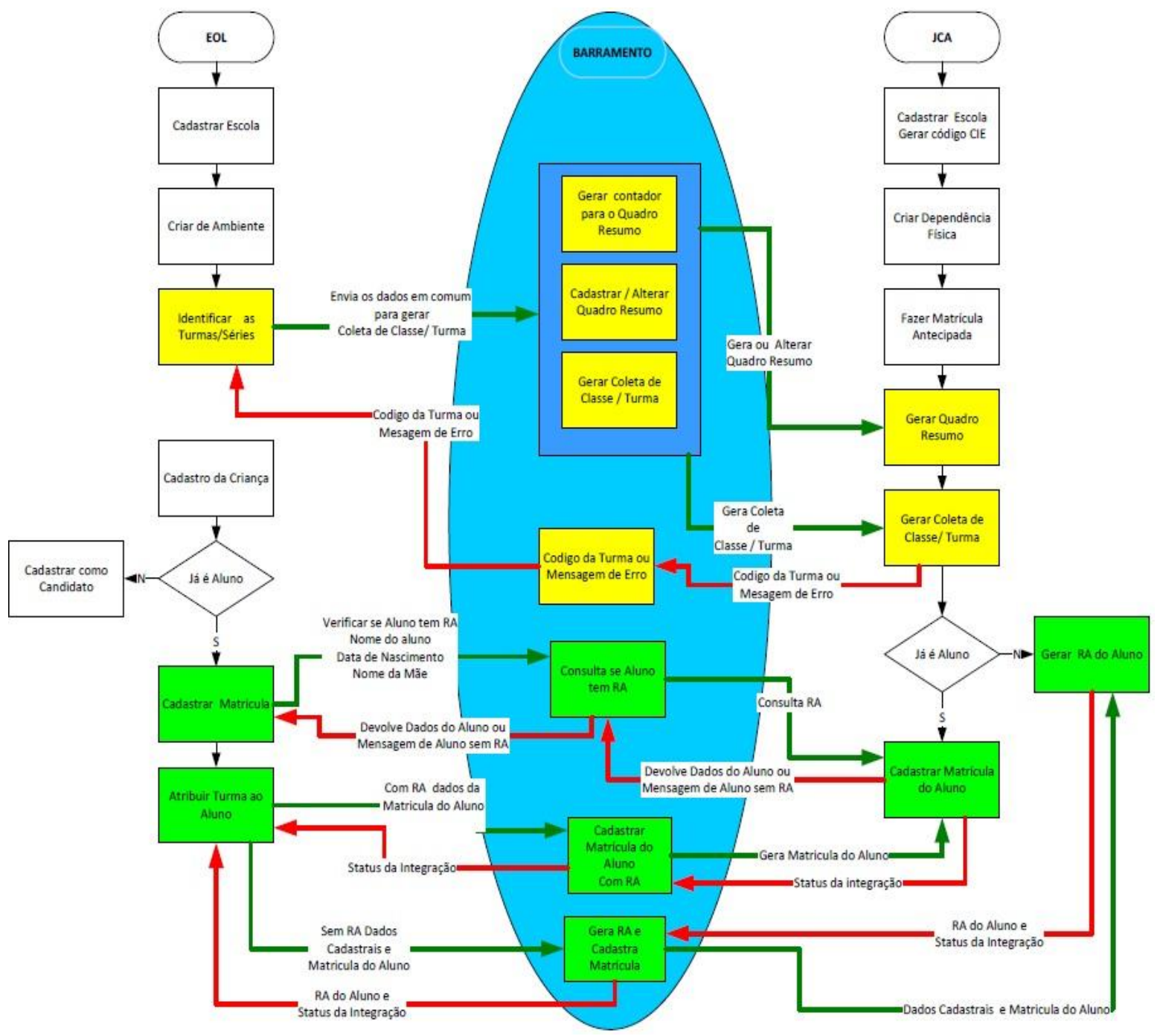

Figura 7: Fluxo de dados EOL x JCA.

Fonte: Secretaria Estadual de Educação, 2012

\subsubsection{O Barramento de Comunicação}

Para a construção do barramento de comunicação foi utilizada a ferramenta Ensemble da Intersystems. Segundo o site do fabricante: "Ensemble é o software de integração mais fácil de usar, pois não é um pacote de partes separadas. Ele foi criado como um pacote de tecnologia único e de forma arquitetural consistente (servidor de integração, servidor de dados, servidor de aplicativo, e software de desenvolvimento de portal)" (INTERSYSTEMS, 2012). Segundo o Diretor da Prodesp, “já tínhamos firmado um 
acordo em novembro de 2009 com a Intersystems para fornecimento do Ensemble quando a Secretaria de Educação apresentou sua necessidade”. O Diretor, então, ligou para a empresa e perguntou se seria possível testar o produto em um POC para a Secretaria de Educação.

O POC - Proof of Concept, é uma forma de avaliação em que a empresa realiza algum serviço para o cliente para provar que o produto funciona em tudo o que foi prometido, sendo o serviço pago e contratado em seguida. Na administração pública não há garantia de contratação do POC, pois seria necessária uma licitação posterior que poderia ser ganha por qualquer fornecedor. Porém, como a Intersystems possuía um acordo, esta etapa não era mais necessária, pois o acordo é fruto de uma licitação.

O Diretor precisava do POC, pois não tinha tempo hábil para licitar outra solução. Poderia construir a camada de integração utilizando os recursos já existentes na Prodesp, mas não conseguiria cumprir o prazo solicitado pelos governantes. O ano de 2010 era um ano eleitoral; em 2011 a administração seria trocada e ele sabia da importância de ser bem avaliado pela nova gestão para manter sua posição na Prodesp.

A empresa concordou em correr os riscos e implantou o sistema na Prodesp, auxiliando no cumprimento dos prazos exigidos. Em 11 de maio de 2010 a diretoria da Prodesp aprovou a contratação da Intersystems por inexigibilidade, que recuperou o investimento realizado, regularizando toda a situação do sistema (TCE-SP, 2011).

\subsubsection{Uso de WebServices}

Para a integração do Ensemble com o EOL foram construídos Web services com base nos processos existentes de geração de arquivo para transmissão em lote. O novo serviço busca as informações de cada registro de turmas, classes, alunos e, finalmente, matrícula dentro das bases de dados do EOL. Então, essas informações são transportadas para a camada de comunicação, na qual os dados são temporariamente armazenados para serem trocados com o JCA. A principal mudança em relação ao método anterior é que, agora, não bastava apenas gerar os arquivos, mas eles tinham que ser entregues de acordo com as necessidades do JCA, como se fosse um operador digitando no sistema. Assim, ao ser gerada nova matrícula, há a necessidade de envio, em sequência, dos dados para confirmação da escola, da classe, da turma e do aluno a ser matriculado. Quando se tratar 
de um novo aluno, esta informação precisa ser gerada no JCA para depois ser encaminhada a matrícula. Se houver divergência nas informações de escola, classe ou turma, a matrícula também não é realizada, sendo ignorada pelo sistema e emitidas mensagens de erro. A tradução dos erros relatados pelo JCA para o EOL é realizada pelo ensemble, que transforma esses erros em solicitações que o EOL apresenta para o usuário do sistema que está tentando uma matrícula.

Assim, o serviço de matrícula é composto de diversos web services, um para cada operação específica, bem como web services de retorno, seja para informar erros ocorridos, seja para confirmar a matrícula realizada com êxito.

Durante a primeira fase de integração apareceram muitos erros não documentados, dificultando a tradução pelo ensemble e inviabilizando as correções no EOL. Assim, para que os pais e alunos não fossem prejudicados, o EOL gerava a matrícula quando o erro não era identificado, e o registro ficava assinalado para envio posterior. Esses erros eram tratados à parte, por outros processos apresentados no capítulo 7.5.4.

\subsubsection{Uso de Robots de Integração}

Para a conexão na outra ponta, a integração do Ensemble com o JCA, foi construído um simulador de operador. Este processo, descrito no capítulo 5.5.2, simula toda a digitação, desde as telas de registro no sistema até a sequência de telas de operação. Todo o workflow do sistema precisa ser analisado para que o robot siga a mesma sequência de ações de forma a evitar erros de processamento. Esse simulador possui construção complexa e qualquer mudança em telas do sistema que altere um campo, a propriedade de um campo ou mesmo sua localização na tela implica em mudanças no robot. Entretanto, parte da estrutura do robot já estava desenvolvida para a troca de arquivos em lote. $\mathrm{O}$ simulador de operações precisava ser adaptado para, ao invés de trabalhar a partir de um arquivo, trabalhar com os dados sendo gerados pela camada de comunicação, o ensemble. Assim, o desenvolvimento da conexão com o JCA seria mais rápido e a um custo menor. No entanto, desde o início os técnicos sabiam que haveria uma perda de desempenho decorrente do fato de que a simulação exigia muito mais operações do que se fosse utilizado um web service, por exemplo. No entanto, o fato das regras de matrícula estarem embutidas nas telas do JCA, dificultava a geração de conexões diretas com o banco de dados, pois não era possível garantir que as regras já estabelecidas seriam cumpridas. 
A busca de homônimos é um exemplo: o sistema possui diversos mecanismos de verificação, desde a comparação direta, fonética, por semelhança, etc. Transpor todas estas regras para a camada de comunicação tornaria o processo mais eficiente, porém geraria um tempo de desenvolvimento muito maior. Como tempo era o fator mais escasso do projeto, optou-se pela solução de menor desempenho, que poderia ser alterada no futuro, salienta Marcos Tadeu.

\subsubsection{Problemas na implantação}

Quando do primeiro envio diversos erros ocorreram, pois os metadados e as regras de validação não foram devidamente analisados. Para tratar os erros e organizar as correções foram definidos diversos fluxos. Um destes fluxos, o de envio de informações sobre classes, é apresentado na figura 8:

\section{Processo "Envio das informações"}

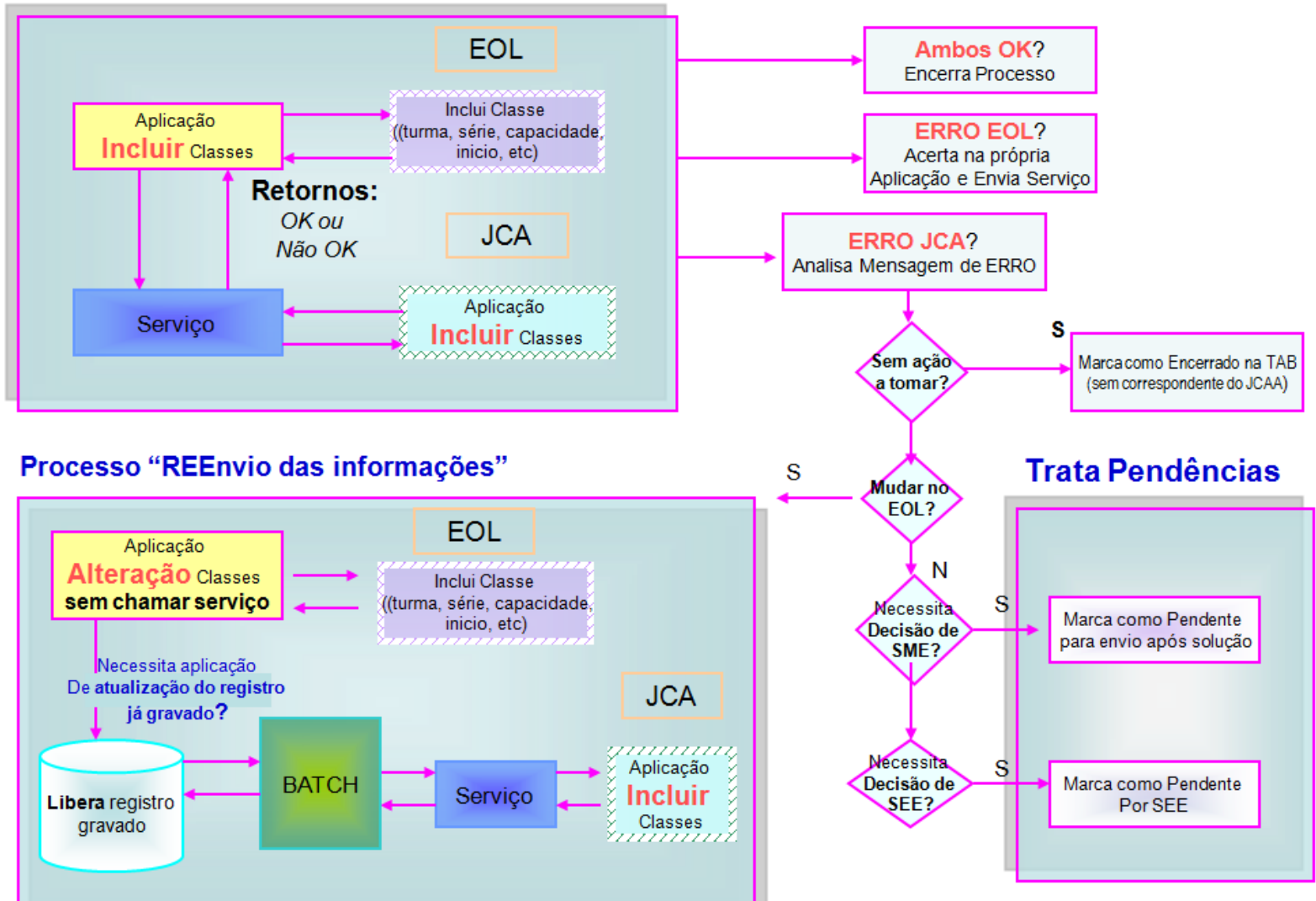

Figura 8: Processos de envio e reenvio de informações entre EOL e JCA.

Fonte: Prodam, 2012 
Como o EOL está em processo de evolução e se encontra em plataforma baixa, os técnicos rapidamente conseguem realizar adaptações no sistema. Assim, se ocorrer um erro de transmissão fruto de problemas internos do EOL, as mudanças são realizadas imediatamente. Quando ocorre erro no JCA são geradas mensagens de erro. As mensagens são analisadas pelas equipes para determinar o tipo de ação a realizar. Se for possível identificar o registro no EOL que gerou o erro e este estiver correto, é gerado um arquivo para transmissão em lote (ignorando o serviço de interoperação entre os sistemas) que é encaminhado para que a Prodesp insira as informações no JCA. Em alguns casos a informação aparece como erro, mas ocorreu a inserção de dados no JCA, sendo o erro ignorado. Em outras situações, a regra de matrícula não é compatível, necessitando de avaliação superior (SME ou SEE) para a correção e reenvio. Os erros continuam acontecendo, tendo sido criado um fluxo para liberação de registros pendentes, apresentado na figura 9:

\section{Processo "Liberação dos registros pendentes"}

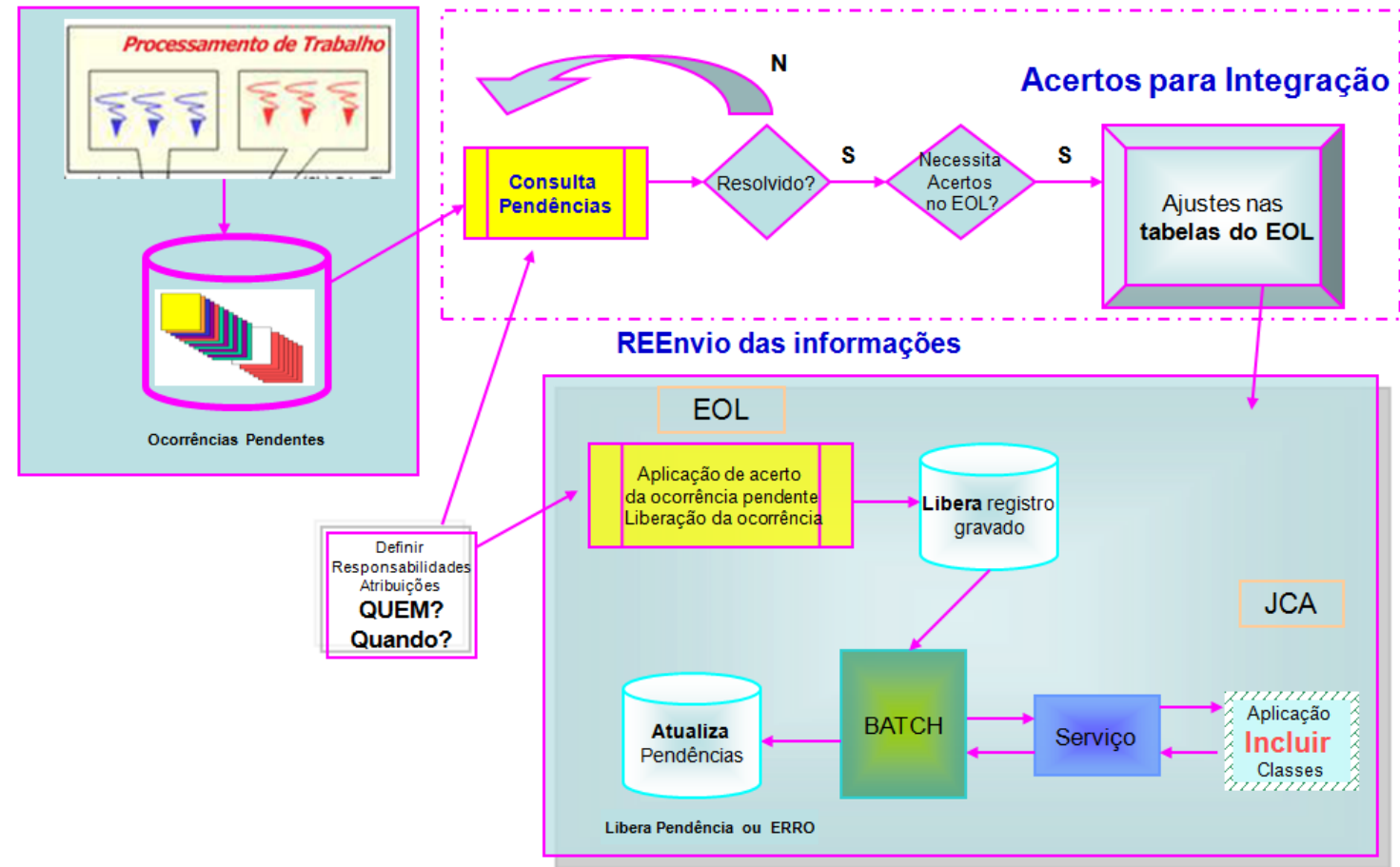

Figura 9: Processo de liberação de registros pendentes na interoperabilidade entre EOL e JCA.

Fonte: Prodam, 2012

A liberação dos registros é realizada por meio de troca de arquivos, sendo ativado novamente o serviço para transmissão dos dados de forma a confirmar que as correções 
realmente liberam o registro gravado. Valmir pontuou que, por diversas noites no período de rematrícula, ele teve de produzir e reenviar arquivos. Era um processo muito semelhante ao que existia anteriormente, ou seja, parte dos dadas não interoperavam entre os sistemas, necessitando de outro mecanismo de transferência. A falha é totalmente atribuída, por Valmir, ao processo de conexão por robots com o JCA. 


\section{RESULTADOS}

Com os esforços empreendidos pela Prodesp e Prodam na construção da solução de interoperabilidade entre os sistemas, apoiadas pelas Secretarias de Educação do Estado e do Município, foram percebidos avanços no processo de matrícula como um todo, mas persistem problemas na troca de dados, resultantes da forma como o processo de desenvolvimento ocorreu e dos procedimentos que não foram adotados (conforme as boas práticas levantadas). Apesar da interoperabilidade entre os sistemas ainda ocorrer de forma incompleta (segundo a definição adotada) e com muitos erros de transmissão, os entrevistados relataram diversos resultados positivos resultantes do fato dos sistemas conseguirem interoperar, apresentados a seguir.

\subsection{No Estado}

Apesar das resistências iniciais, os técnicos do Estado são unânimes em afirmar que a interoperabilidade entre os sistemas resultou em melhorias no processo de matrícula:

1. O processo ficou muito mais ágil, com as escolas conseguindo realizar novas matrículas em tempo real, informando os pais sobre a possibilidade de vaga em cada escola de forma a atender melhor os alunos;

2. O número de crianças com problemas na matrícula diminuiu consideravelmente;

3. Ficou mais clara a distribuição de vagas na capital, bem como os critérios de matrícula, levando as equipe a um entendimento maior;

4. Foi percebido que a interoperabilidade pode ser expandida para outros municípios, sendo analisada para os sistemas dos municípios de Osasco, São Bernardo e Guarulhos, na região metropolitana de São Paulo, entre outros. Um dos objetivos é eliminar os problemas de crianças migrantes, que aparecem matriculadas em municípios diferentes. 


\subsection{No município}

Para os técnicos da Prodam e integrantes da Secretaria Municipal de Educação os efeitos da interoperabilidade com o sistema do Estado foram ainda mais significativos:

1. Eliminou-se a necessidade, nas escolas, de dupla digitação (EOL e JCA);

2. O processo de matrícula antecipada ficou extremamente simplificado, praticamente eliminando a possibilidade de falha humana na troca de informações;

3. As novas matrículas passaram a ser realizadas diretamente no EOL, simplificando o trabalho nas escolas e diretorias de ensino;

4. A alocação de salas tornou-se mais ágil, permitindo um atendimento personalizado aos pais e alunos.

Alexandre Schneider coloca que "o sucesso da interoperabilidade entre os sistemas auxiliou na minha imagem junto ao Governador e o Prefeito, ampliando minhas possibilidades políticas”. Na conclusão desta dissertação, Schneider fora escolhido para ser o vice na chapa apoiada pelo Prefeito e pelo Governador, corroborando a visão positiva sobre seu trabalho na Secretaria de Educação do município.

No entanto, os técnicos ainda consideram que muito há para fazer, principalmente no Estado, pois a falta de uma conexão real da camada de comunicação com o JCA e o fato das regras não serem compartilhadas, complica muito o processo. Na visão de Valmir Aquilino de Freitas, da Secretaria Municipal de Educação, há a necessidade de um trabalho maior na definição das regras de matrícula para evitar que os erros continuem, bem como o compartilhamento destas regras por todos os municípios do Estado.

Para o Estado, o saldo da interoperabilidade foi positivo. Quando os problemas com as matrículas forem superados, a Secretaria de Educação pretende interoperar outros módulos, tais como os que tratam das informações sobre transporte escolar e merenda. Mas, apesar da interoperabilidade com outros municípios ser cogitada, os técnicos da secretaria ainda olham com restrições a expansão de todos os sistemas do Estado.

Resumindo, a interoperabilidade entre os sistemas que gerenciam as matrículas no município e no Estado de São Paulo, EOL e o JCA, foi construída utilizando-se uma camada intermediária de integração, web services e robots. Os metadados não foram 
plenamente trabalhados, provocando erros durante as transferências de dados que exigiram alterações no EOL e nos web services, para gerar a compatibilidade necessária. As regras de operação, necessárias para que os alunos sejam alocados corretamente, não foram compartilhadas, existindo divergências entre os sistemas.

Com isto, parte dos dados que deveriam ser trocados se perde ou os dados são bloqueados, exigindo uma intervenção humana para realizar as correções necessárias. Esta situação resulta em uma interoperabilidade incompleta dentro da definição que adotamos: interoperabilidade é a habilidade de dois ou mais sistemas governamentais interagirem e intercambiarem dados, de acordo com um método definido, de forma a obter os resultados esperados.

No caso em estudo os sistemas adquiriram a possibilidade de interagirem $\mathrm{e}$ intercambiarem dados, principalmente quando de novas matrículas, mas o processo de matrícula antecipada ocorre com erros, ou seja, não são obtidos os resultados esperados em sua totalidade.

\subsection{Conclusões}

No caso estudado percebemos que a interoperabilidade é um processo permanente, que acompanha a evolução dos próprios sistemas. Também fica claro que, se o desenvolvimento ocorresse evitando-se os problemas clássicos, já documentados, a situação seria melhor. Para tanto, vamos realizar uma comparação dos resultados com a literatura estudada:

Da entrevista com os integrantes da Secretaria Municipal de Educação ficou evidente que a interoperabilidade influenciou positivamente na eficiência dos sistemas. A Diretora da Escola Municipal cita diretamente que "essa integração, essa matrícula em conjunto integrada ou dentro do sistema, ela enquanto sistema de gerenciamento numa rede imensa, ela é muito eficiente, porque ela faz rápido, ela não deixa a criança estar em duas escolas ao mesmo tempo, você só consegue, você tem precisamente, clica em um botão e você tem na hora onde está aquele aluno dentro do Estado ou dentro do município ou em qual escola, então você tem uma agilidade muito grande, e a criança fica mais garantida do ponto de vista do direito, independente se a mãe trouxe o papel ou não trouxe o papel. Isso era um ranço que as escolas tinham, então ficavam assim: 'ah não tem isso'; agora é 
assim, se estiver ou não, efetiva matrícula lá no sistema; você faz a matrícula e a criança vem imediatamente assistindo aula, depois você fica atrás do papel, para montar prontuário. Antes as escolas ficavam embaçando."

Pelos relatos, fica claro que a definição de dados foi um dos fatores que prejudicaram a implantação, fator já estudado por Arcieri et Al (2002), que reproduzimos novamente: "um dos objetivos mais difíceis de alcançar em um desenvolvimento de sistemas de informação cooperativos é a coerência dos conjuntos de dados, geralmente distribuídos". A necessidade de evitar o problema com a má definição de metadados também foi objeto do modelo desenvolvido para o Estado, apresentado por Albuquerque Filho e Pessi (2010). Lembrando, Santos (2001) considera que "a resolução política dos conflitos [...] é pressuposto fundamental para equilíbrio e a estabilidade das soluções adotadas".

Analisando o caso segundo os fatores de Vassilakis e Lepouras (2006), temos:

Combinação da prestação de serviços em determinado momento da vida do cidadão ou da empresa;

1) Os serviços foram catalogados com múltiplas taxonomias, atendendo o primeiro fator;

2) Enquanto o EOL possui modelagem que permite adaptação mais rápida às mudanças de legislação ou processos, o JCA não, dificultando a desburocratização de serviços e não atendendo ao segundo fator;

3) Os responsáveis administrativos em cada etapa, que garantam a manutenção de padrões, foram definidos, porém os padrões não foram acordados, deixando incompleto o atendimento ao terceiro fator, pois para que o atendimento ocorresse os padrões deveriam ser respeitados não apenas nos metadados, mas também nas regras de negócios, o que não ocorreu.

Ainda analisando segundo estes autores, as definições de metadados não foram conclusivas, não há documentação do sistema estabelecida (nem mesmo manual do usuário - nas duas secretarias o que há são apresentações de suporte a aulas presenciais sobre a utilização dos sistemas, mas não um manual estruturado de uso) e a legislação sobre matrícula permite interpretações díspares, como no caso das crianças que completam 7 anos durante o período letivo inicial, ou seja, as regras não estão claras no 
processo, dificultando a automação. Analisando o processo conforme as dimensões de

Pardo e Burke (2008) foi construída a tabela a seguir:

Tabela 13: Dimensões da Interoperabilidade de Pardo e Burke aplicadas ao caso

\begin{tabular}{|c|c|}
\hline Dimensão & Como foi desenvolvida no caso em estudo \\
\hline GOVERNANÇA & $\begin{array}{l}\text { A iniciativa estava alinhada com o desejo dos dirigentes, fazia parte das } \\
\text { prioridades e metas definidas no planejamento estratégico do Estado } \\
\text { (conduzido pela corregedoria). Existiam regras e procedimentos que foram } \\
\text { aplicadas no desenvolvimento das soluções por serem padrão da Prodesp e } \\
\text { da Prodam, porém não foram aplicadas para definir o que seria } \\
\text { desenvolvido nem nas ações que dependiam de decisões dos técnicos das } \\
\text { Secretarias. A governança existiu, mas de forma precária. }\end{array}$ \\
\hline $\begin{array}{l}\text { PLANEJAMENTO } \\
\text { ESTRATÉGICO }\end{array}$ & $\begin{array}{l}\text { O planejamento estratégico foi realizado às pressas e sem consenso. Não } \\
\text { foram previstos todos os recursos, muito menos a integração com outros } \\
\text { elementos de gestão. }\end{array}$ \\
\hline $\begin{array}{l}\text { DESENVOLVER CASOS } \\
\text { DE SUCESSO }\end{array}$ & $\begin{array}{l}\text { Existiram casos de sucesso em integração de outras áreas e na } \\
\text { interoperabilidade, em especial no projeto piloto realizado na geração do } \\
\text { Modelo estadual com o município de Sud Mennucci. Porém, o que } \\
\text { realmente convenceu os técnicos foi a ordem superior para executar. }\end{array}$ \\
\hline GESTÃO DE PROJETOS & $\begin{array}{l}\text { As equipes envolvidas sabiam do prazo exíguo para a realização do projeto } \\
\text { e se articularam bem para isso. As metodologias de gestão de projetos } \\
\text { adotadas pela Prodesp e Prodam garantiram que os prazos fossem } \\
\text { cumpridos. }\end{array}$ \\
\hline $\begin{array}{l}\text { IDENTIFICAÇÃO DOS } \\
\text { PRINCIPAIS ATORES }\end{array}$ & $\begin{array}{l}\text { Desde o início do projeto os atores estavam bem definidos, com } \\
\text { responsabilidades estabelecidas. }\end{array}$ \\
\hline $\begin{array}{l}\text { ARQUITETURA } \\
\text { TECNOLÓGICA }\end{array}$ & $\begin{array}{l}\text { A arquitetura tecnológica foi decidida levando-se em conta a escassez de } \\
\text { recursos: tempo e orçamento. Segundo Marcos Tadeu "desde o princípio } \\
\text { sabia-se que não era a solução ideal, mas era a viável". }\end{array}$ \\
\hline $\begin{array}{l}\text { AVALIAÇÃO } \\
\text { DESEMPENHO }\end{array}$ & $\begin{array}{l}\text { Neste quesito a atuação das equipes foi exemplar. Todos os relatos apontam } \\
\text { para uma correta avaliação de desempenho, mesmo o desempenho não } \\
\text { sendo o adequado. A aparente dicotomia se deve ao desalinhamento entre } \\
\text { expectativas e entregas: sabia-se que o modelo adotado poderia gerar os } \\
\text { erros que gerou, porém realizar as ações necessárias para minimizar estes } \\
\text { erros estava além do alcance dos envolvidos e não era consensual. }\end{array}$ \\
\hline COLABORAÇÃO & $\begin{array}{l}\text { A colaboração foi essencial para que o projeto avançasse. Nas entrevistas } \\
\text { todos salientaram a importância das equipes estarem trabalhando alinhadas, } \\
\text { sendo que os problemas foram fruto dos momentos em que não havia este } \\
\text { alinhamento. }\end{array}$ \\
\hline $\begin{array}{l}\text { COMPATIBILIZAÇÃO } \\
\text { DAS ORGANIZAÇÕES }\end{array}$ & $\begin{array}{l}\text { Entre o município e o Estado há compatibilização apenas das informações } \\
\text { necessárias e os estilos de trabalho são diferentes, apesar das estruturas } \\
\text { serem semelhantes. A situação dificultou as relações interpessoais e por } \\
\text { consequência a tomada de decisões e a solução de conflitos. }\end{array}$ \\
\hline $\begin{array}{l}\text { POLÍTICA } \\
\text { TRATAMENTO } \\
\text { INFORMAÇÃO }\end{array}$ & $\begin{array}{l}\text { As políticas de tratamento da informação foram claras. A dificuldade foi na } \\
\text { definição de regras relacionadas às informações. }\end{array}$ \\
\hline GESTÃO DE MUDANÇAS & $\begin{array}{l}\text { A equipe do Estado é mais resistente à mudanças do que a equipe do } \\
\text { município. Porém, o próprio processo ampliou a visão de todas as equipes, } \\
\text { que agora compreendem que a mudança pode ser positiva. O trabalho das } \\
\text { equipes de desenvolvimento no envolvimento de todos os atores foi } \\
\text { essencial para o processo. }\end{array}$ \\
\hline SEGURANÇA & Esta é uma das falhas verificadas no caso. A documentação é insuficiente, \\
\hline
\end{tabular}




\begin{tabular}{|l|l|}
\hline INFORMAÇÃO & $\begin{array}{l}\text { os dados ainda são trocados de forma precária durante a matrícula } \\
\text { antecipada. No entanto, protocolos de segurança adequados para os dados, } \\
\text { aplicações, sistemas e redes existem e são utilizados. }\end{array}$ \\
\hline $\begin{array}{l}\text { COMPATIBILIDADE } \\
\text { TECNOLÓGICA }\end{array}$ & $\begin{array}{l}\text { Do micro da escola municipal, em que são inseridos os dados de matrícula, } \\
\text { até a base de dados do JCA o processo passa por micro, baixa e alta } \\
\text { plataforma, cinco sistemas operacionais diferentes, quatro linguagens de } \\
\text { informação e bases de dados de três fornecedores distintos. A } \\
\text { compatibilidade tecnológica foi criada pelo projeto, não sendo possível a } \\
\text { troca de dados de forma mais eficiente que a interoperabilidade entre os } \\
\text { sistemas, segundo Norberto Torres. }\end{array}$ \\
\hline
\end{tabular}

Vê-se que a interoperabilidade estudada enfrentou diversos problemas relatados, que poderiam ser evitados se as orientações dos autores citados tivessem sido adotadas. A situação apresentada é fruto do desconhecimento, detectado nas pesquisas do comitê gestor da e-ping (SLTI, 2007) e por Garda (2011).

A camada de comunicação, ou plataforma comum de integração (ou camada de interoperabilidade) é um fator positivo do projeto, sendo corroborada por Diniz (2005) e pelo modelo estadual.

Como complemento a estas análises, durante as entrevistas foi perguntado sobre a existência de fatores que influenciaram positivamente ou negativamente o processo, bem como vantagens e desvantagens decorrentes. Para estas questões os entrevistados apresentaram respostas convergentes. Assim, ao invés de apresentar o relato de cada um, as respostas foram agrupadas, definindo alguns fatores. No entanto, para cada fator identificado mencionamos os entrevistados que citaram este fator. Os resultados desta análise são apresentados a seguir.

\subsubsection{Fatores que Influenciaram positivamente o processo}

\section{A solução tecnológica}

Os técnicos da Prodesp e da Prodam, além do Superintendente da FDTE, citaram nas entrevistas a e-PING, o modelo estadual e a facilidade de desenvolver os mecanismos necessários para habilitar os sistemas a interoperarem. Todas as soluções tecnológicas eram conhecidas e as empresas dispunham dos meios para realizar tecnicamente o projeto. A tecnologia nunca foi problema, sempre a solução.

\section{O apoio do alto escalão}


Houve unanimidade em afirmar que o fato do prefeito e do governador apoiarem o projeto pode ser considerado como o principal fator que impulsionou o processo. Não apenas o apoio, mas o fato da decisão ter sido "de cima para baixo", ou seja, uma decisão do primeiro escalão com ordem de ser cumprida. Nessas situações dificilmente os resultados não aparecem, mesmo que existam resistências dos setores inferiores.

\section{A pressão da opinião Pública}

Interessante notar que no relato dos técnicos que não citaram esta questão fica evidente que a interoperabilidade já estava sendo debatida e discutida internamente, porém sem avanços práticos na implantação. Quando um problema causado aparentemente por uma falha de sistema (que na verdade era uma falha operacional decorrente da falta de comunicação e do interesse de cada secretaria) levou a uma notícia em um veículo de grande repercussão, os agentes públicos foram obrigados a dar uma resposta. A sociedade, assim, por meio dos canais de comunicação, teve influência positiva no processo. Essa influência foi citada pelo Secretário Municipal, o Chefe de Gabinete do Estado, o Coordenador do GEDAE, o responsável pelo JCA, pelo Assessor Técnico Municipal e pelo Desenvolvedor.

\section{O interesse dos técnicos}

Nas entrevistas, os técnicos municipais explicitavam o interesse na interoperabilidade entre os sistemas. Por esse motivo ofereceram total apoio ao projeto, permitindo que a interoperabilidade, ao menos com o sistema municipal, fosse completa. $\mathrm{O}$ interesse da equipe em realizar o projeto foi diretamente citado pelos técnicos da Prodam e da Secretaria de Educação, e pode ser aferido nas entrevistas do Superintendente e do Chefe de Gabinete.

Outros fatores foram citados, mas apenas por alguns entrevistados. O Superintendente citou a relevância de uma figura central com interesse em conduzir o processo. Os integrantes da Secretaria Estadual de Educação citaram a relevância de um sistema bem estruturado para definir a interoperabilidade contra outras soluções. Os integrantes da Prodam citaram a importância do conhecimento técnico para a implantação do processo. O Secretário Municipal, o Presidente e o Corregedor comentaram a relevância do trabalho coordenado para o sucesso do projeto. O Diretor da Prodesp e o Superintendente da FDTE citaram a experiência acumulada pelos atores para garantir o sucesso das novas iniciativas. 


\subsubsection{Fatores que dificultaram o processo}

\section{Falta de interesse dos técnicos}

Se por um lado os técnicos do município se interessavam pela troca direta de dados entre os sistemas, o mesmo não ocorria com os técnicos estaduais. Esclarecedor notar que os problemas de interoperação entre os sistemas são majoritariamente estaduais, pois as mudanças no sistema estadual foram realizadas com menor intensidade. Os fatos corroboram a necessidade de envolvimento dos técnicos no processo para uma efetiva implantação. Essa falta de interesse foi percebida indiretamente nos relatos dos integrantes da Secretaria Estadual e do Diretor da Prodesp, que tornavam evidente que o problema levantado pelo município não era um problema para o Estado. O Diretor da Prodesp chegou a declarar que o ideal seria eliminar o sistema municipal, pois o sistema estadual era capaz de executar todos os processos relevantes. Este apego ao sistema (que a Coordenadora do GEDAE chegou a chamar de filho) beira a irracionalidade, mas é fruto de zelo por parte dos gerenciadores do sistema.

O projeto começou a avançar quando os técnicos foram convencidos de que a solução não prejudicaria o sistema estadual e ao verem os primeiros resultados, quando ficou claro que o serviço gerava vários benefícios, não sendo um risco para o JCA.

\section{Falta de documentação dos sistemas}

Ambos os sistemas são da década de 90 do século passado. O EOL ainda passou por um processo de modernização que documentou parte do sistema, mas o JCA possui muitos códigos embutidos em telas que não estão claros. O Assessor Técnico Municipal comentou que muitas mensagens de erro durante a execução do serviço eram desconhecidas até dos técnicos da SEE. Os outros técnicos municipais e estaduais envolvidos com o projeto corroboram que a falta de documentação é um problema.

Para contornar a situação, as operações eram realizadas manualmente, a fim de possibilitar a compreensão de onde estava o erro e então realizar a correção. A partir dos erros, a documentação passou a ser produzida, havendo, hoje, mais clareza sobre cada sistema. O Diretor da Prodesp cita este trabalho de documentação como uma das consequências do processo.

\section{Metadados não padronizados}


A falta de um padrão claro para a estrutura de metadados dos dois sistemas dificultou o trabalho dos técnicos, pois a troca de informações falhava.

A solução foi buscar a definição usada no processo anterior de troca de arquivos em lote, para compreender a estrutura dos dados. A partir desta pré-estrutura foi possível definir com os técnicos as lacunas encontradas. Hoje, os sistemas possuem os metadados definidos, ao menos no processo de matrícula. Todos os técnicos foram unânimes em levantar esta questão.

\section{Regras de negócio díspares}

Para a população, não deveria haver regras diferentes para matrícula no estado ou no município, mas não é isso que ocorre. Já foi citado o problema com as idades escolares, mas existem definições diferentes sobre número de alunos em sala de aula (o município limita em trinta; no Estado, o limite é quarenta, podendo ser aumentado para evitar que o aluno não tenha onde estudar), a distância da residência do aluno em relação à escola, entre outras. A matrícula em creches é exclusiva do município, mas ainda existem escolas estaduais de ensino fundamental e médio, além das escolas particulares. As regras não são claras e Integrantes da Secretaria de Estado de Educação colocam que o problema está no município, que insiste em criar regras diferenciadas. Já o Secretário Municipal, seu assessor e o técnico da Prodam colocam que o Estado poderia compreender as peculiaridades do município e respeitá-las, resolvendo o problema. De qualquer forma, enquanto não houver um consenso sobre este assunto os problemas continuarão existindo.

\section{Uso de Robots de integração}

Uma questão relevante, mas que foi citada apenas pelos técnicos municipais, é a solução adotada para a conexão com o JCA: ao se trabalhar com robots tem-se uma queda de desempenho que, se em um primeiro momento parece irrisória, se torna relevante e problemática quando são realizados mil acessos simultâneos ou a transmissão de mais de um milhão de dados em uma única ação. É o que ocorria na matrícula antecipada e no período de matrícula regular. Por isso, vários dados se perdiam, gerando os problemas relatados anteriormente. O problema também foi mencionado indiretamente pelos integrantes da Secretaria Estadual, quando citaram a permanência da necessidade de troca de arquivos mesmo com a interoperabilidade implantada. Essa situação é consequência do fato do sistema estadual ser estanque, construído de forma a impedir a interoperabilidade. A continuidade de um sistema com este formato apenas retarda a modernização do 
Estado, mas os interesses e a cultura organizacional dos envolvidos impede a mudança, que só ocorrerá quando novo problema grave surgir, ou quando um dirigente mais esclarecido resolver enfrentá-lo.

Uma das dificuldades apontada de forma unânime foi o prazo exíguo para a execução, fruto da forma como a decisão de implantação ocorreu, restando como única alternativa trabalhar com maior intensidade na solução. Outros problemas - tais como a falta de governança e planejamento do processo - não foram muito citados, mesmo sendo claro para um observador externo como estes fatores interferiram no processo.

\subsubsection{Ações Futuras}

Os integrantes da secretaria estadual mencionaram a possibilidade de interoperar outros sistemas integrantes do GDAE, bem como realizar o processo com outros municípios. O Diretor da Prodesp pensa na reestruturação do sistema do Estado, prevendo baixar a plataforma, se necessário, ou ao menos modernizar os programas atuais. O EOL se encontra em processo de modernização e atualização de todos os processos, visando construir um sistema que atenda ainda melhor às necessidades da Secretaria de Educação do Município e das escolas.

Foram avaliados os benefícios gerados e os correlacionamos com as informações da revisão bibliográfica para compreendermos em que medida o caso auxilia no estudo da implantação da interoperabilidade. Com isso conseguimos mostrar, de forma sintética, a relevância do caso junto aos estudos já realizados.

Ao verificarmos a matriz de resultados de Scholl e Klischewski podemos constatar que houve resultados desejados e indesejados no processo. Alguns resultados desejados não aconteceram, porém os principais foram efetivados, o que garantiu a eficiência do processo.

Dentre as restrições percebidas no caso, a novidade fica por conta da opinião pública, não diretamente citada,mas que pode ser classificada como um catalisador ou restrição político.

A interoperabilidade entre o Sistema de Matrículas do Estado de São Paulo - JCA e o Sistema de Gerenciamento Escolar do Município de São Paulo - EOL foi uma experiência de sucesso, com significativas melhorias na eficiência do processo tanto para 
o usuário final quanto nos trâmites internos. Apesar da interoperabilidade não estar completamente implantada, as equipes demonstraram que é possível a troca de informações e dados com benefícios para ambos os governos. A expansão destas ações, de forma a ampliar a interoperabilidade em governo, parece ser uma tendência e uma evolução natural dos sistemas governamentais.

Por fim, o fato de ter sido implantada a interoperabilidade entre sistemas de matrículas escolares demonstrou aos envolvidos e a outros integrantes do Estado que se trata de uma ação possível e viável. Com isso, espera-se que novos casos de troca de informações por interoperabilidade de sistemas governamentais ocorram e que levem a uma modernização e desburocratização do Estado que, evoluindo ao longo do tempo, resultem em uma mudança interna no governo, significativa para os cidadãos.

\subsection{Questões não esclarecidas}

Levando em consideração os objetivos secundários deste trabalho, não conseguimos esclarecer plenamente os fatores determinantes de um processo de interoperabilidade governamental. Se por um lado o processo em análise se encontra alinhado com práticas já documentadas, permitindo uma comparação com questões já estudadas, questões como a influência política, bem como a interferência da sociedade no processo, não foram completamente esclarecidas. Não há consenso entre os entrevistados, nem na teoria estudada, sobre que fatores preponderantes ou mesmo relevantes nesta interferência não técnica. Assim, uma sugestão para pesquisas futuras é compreender melhor a interferência sociológica, antropológica e política na interoperabilidade de sistemas governamentais.

\subsection{Limitações do Estudo}

Este trabalho se limita a identificar os fatores que influenciaram a adoção, dentro da Secretaria de Educação do Estado de São Paulo, da interoperabilidade com o sistema municipal de gerenciamento escolar, o EOL, bem como seus desdobramentos no período estudado. Não serão aprofundadas as questões tecnológicas e sociológicas de todos os 
fatores detectados e suas implicações, apenas os relevantes para compreender o impacto na produtividade e satisfação dos funcionários pesquisados. Sendo assim, o trabalho é limitado no tempo e espaço, se referindo à realidade do município e do Estado de São Paulo, não podendo ser generalizado para outras realidades automaticamente, bem como possui uma limitação de escopo, pois a interoperabilidade de sistemas governamentais pode acontecer de forma diversa da apresentada, não sendo objeto deste estudo analisar alternativas ao modelo proposto e realizado pelas secretarias de educação. Tendo o arcabouço teórico e a contextualização do caso, passamos à descrição do mesmo, mantendo a relação com o já apresentado e identificando pontos de similaridade e diferenças em relação ao já estudado, principalmente quanto às dificuldades e facilidades da implantação. 
Albuquerque FILHO, A. C. D. P. $1^{0}$ Seminário de Gestão Integrada Para Estados e Municípios. Gestão Integrada. São Paulo: Fundação Prefeito Faria Lima Cepam. 2009. p. 25.

ALBUQUERQUE FILHO, A. C. D. P.; PESSI, P. Modelo de Interoperabilidade para Municípios do Estado de São Paulo: integrando sistemas com compartilhamento, reúso e itercâmbio de informações. Primeira Edição. ed. São Paulo: Fundação Prefeito Faria Lima - CEPAM, 2010. 76 p.

ALMEIDA, M. H. B. T. D. O estado no Brasil contemporâneo: um passeio pela história. In: MANUEL ALCÁNTARA SÁEZ, C. R. M. (. ). A democracia brasileira: balanço e perspectivas para o século 21. Belo Horizonte: Ed. UFMG, 2007. p. 17-37.

ALMEIDA, O. D. EOL - Escola On-Line. Cidades do Brasil, Curitiba, n. 07, Março 2000.

ANATEL. Anatel - Agência Nacional de Telecomunicações. SACP: acompanhamento de consultas públicas, 2010. Disponivel em: <http://sistemas.anatel.gov.br/sacp/ >. Acesso em: 31 ago. 2012.

ARCIERI ET AL, F. A Reference Architeture for the certification of e-services in a digital government infraestructure. Hingham: Academic Publishers, 2002.

BARBOSA, A. F.; CAPPI, J.; GATTO, R. Os caminhos para o avanço do governo eletrônico no Brasil. CGI.Br, 2009. Disponivel em: <http://cgi.br/publicacoes/artigos/artigo63.htm>. Acesso em: 11 novembro 2011.

BELL, D. O advento da sociedade pós-industrial. $2^{\text {a }}$. ed. São Paulo: Cultrix, 1978.

BERTUCCI, G. (. ). United Nations e-Government Survey. New York: United Nations, 2008 .

BLAIR, K. The "Small World Experiment": Yahoo and Facebook Help Research Six Degrees of Separation. Social Times, 2011. Disponivel em: <http://socialtimes.com/thesmall-world-experiment-yahoo-and-facebook-help-research-six-degrees-ofseparation_b74963>. Acesso em: 26 fev. 2013. 
BONI, V.; QUARESMA, S. J. Aprendendo a entrevistar: como fazer entrevistas em Ciências Sociais. Em Tese, São Carlos, v. Vol. 2, n. nº 1 (3), p. p. 68-80, janeiro-julho 2005.

BONOMA, T. V. Case Research in Marketing: Oportunities, Problems and Process. Journal of Marketing Research, Chicago, XXII, May 1985.

BOVENS, M. Public Accountability. The Oxford Handbook of Public Management, p. $182-208,2007$.

BRANCO, M. A. F. Sistemas de informação em saúde no nível local. Caderno de Saúde Pública, Rio de Janeiro, v. 12, p. 267-270, abr-jun 1996.

BRESSER PEREIRA, L. C. Da Administração Pública Burocrática à Gerencial. Revista do Serviço Público, Rio de Janeiro, v. ano 47 v. 120 nº 1, p. 07-34, janeiro-abril 1996.

BRESSER PEREIRA, L. C. Gestão do setor público: estratégia e estrutura para um novo Estado. In: BRESSER PEREIRA, L. C.; SPINK, P. K. (. ). Reforma do Estado e Administração Pública Gerencial. $2^{a}$ ed. ed. Rio de Janeiro: Editora Fundação Getúlio Vargas, 1998.

CAMPOS, R. M. C. O Governo Eletrônico e os sistemas de informação públicos em Portugal. Covilhão: Universidade da Beira Interior, 2006.

CASTELlS, M. A Sociedade em Rede. $6^{\text {a }}$ edição, $13^{\text {a }}$ Reimpressão. ed. São Paulo: Paz e Terra Ltda, v. 1, 2010.

CEPAM. Missão. Cepam, 2008. Disponivel em: <http://www.cepam.sp.gov.br/index.php?option=com_content\&task=view\&id=1\&Itemid =2>. Acesso em: 15 Setembro 2012 .

CGI-BR. Pesquisa sobreo uso das Tecnologias da Informação e da Comunicação no Brasil: TIC Governo Eletrônico. 1ª Edição. ed. São Paulo: CGI-Br, 2010.

CGU. Resolução Conjunta CC/SGP/PGE-1 de 9-4-2007. Corregedoria, 2007. Disponivel em: $<$ http://www.corregedoria.sp.gov.br/adm/conteudo/Resolu\%C3\%A7\%C3\%A3o\%20Conj unta\%20CC-SGP-PGE,\%20de\%2009.04.2007.htm>. Acesso em: 12 março 2012.

CHIAVEnAtO, I. Teoria Geral da Administração. Edição Revista. ed. São Paulo: McGraw-Hill do Brasil, v. 1, 1979. 
CHIZZOTTI, A. Pesquisa qualitativa em ciências humanas e sociais. $3^{\text {a }}$ Edição. ed. Petrópolis, RJ: Editora Vozes, 2010.

CNI/IBOPE. Pesquisa CNI-IBOPE - Retratos da Sociedade Brasileira: Segurança Pública. Brasília: CNI, 2011. 65 p.

COELHO, E. M. Governo Eletrônico e seus impactos na estrutura e na força de trabalho das organizações públicas. Revista do Serviço Público, Brasília, 2001. ISSN Número 2.

COMITÊ EXECUTIVO DE GOVERNO ELETRÔNICO. E-ping, Padrões de Interoperabilidade de Governo Eletrônico. República Federativa do Brasil. Brasília. 2008. (versão 4.0).

COMITÊ EXECUTIVo DE GOVERnO ELETRÔNICO. E-Ping, Padrões de Interoperabilidade de Governo Eletrônico. Versão 4.0. ed. Brasília: Governo do Brasil, 2012.

COMMISSION, E. alis_brochure_en.pdf. EuropeAid Co-operation Office, 2004. Disponivel em: <http://ec.europa.eu/europeaid/where/latin-america/regionalcooperation/alis/documents/alis_brochure_en.pdf>. Acesso em: Outubro 2011.

COSTA, V. M. F. Federalismo e Relações Intergovernamentais: implicações para a reforma da educação no Brasil. Educação \& Sociedade, Campinas, 31 - n.112, jul-set 2010. 729-749.

CRIADO, J. I.; GASCOU, M.; JIMÉNEZ, C. E. Bases para uma Estratégia Iberoamericana de Interoperabilidade. Documento para a consideração da XII Conferência Ibero-americana de Ministros de Administração Pública e Reforma do Estado. Buenos Aires, Argentina: CLAD. 2010. p. 54.

CS TRANSFORM. e-Government Interoperability - A comparative analysis of 30 countries. CS Transform White Papers. Londres, p. 16. 2011.

CUNHA, M. X. C. D.; SOUZA JUNIOR, M. F. D.; ALMEIDA, H. O. D. Dificuldades com integração e interoperabilidade de sistemas de informação nas instituições públicas de ensino - um estudo de caso no CEFET-AL. anais do XII SIMPEP. Bauru SP: [s.n.]. 2005. p. 11.

DA FONSECA, C. E. C.; MEIRELLES, F. D. S.; DINIZ, E. H. Tecnologia Bancária no Brasil, uma história de conquistas, uma visão de futuro. Edição Comemorativa dos 20 
anos da CIAB. ed. São Paulo: FGV RAE, 2010. 420 p. Coordenação editorial Sônia Penteado.

DCMI. The Dublin Core® Metadata Initiative, 2012. Disponivel em: <http://dublincore.org>. Acesso em: Abril 2012.

DIAS, I. D. M. A relação entre a reforma da administração pública e tecologias da informação no Governo do Estado de São Paulo. Universidade de São Paulo. São Paulo, p. 169. 2008. Tese.

DINIZ, E. H. et al. O governo eletrônico no Brasil: perspectiva histórica a partir de um modelo estruturado de análise. REvista de Administração Pública - RAP, Rio de Janeiro, (1), Jan/Fev 2009. 23-48.

DINIZ, V. A história do uso da tecnologia da informação na gestão pública brasileira através do CONIP - Congresso de Informática Pública. X Congresso Internacional del CLAD sobre la Reforma del Estado Y de la Administración Pública. Santiago: [s.n.]. 2005 .

DONEDA, D. O Registro Único de Identidade Civil entre a cidadania e o controle. Surveillance in Latin America - Vigilância, Segurança e Controle Social. Curitiba: PUCPR. 2009.

DRUCKER, P. F. Sociedade Pós-capitalista. São Paulo: Pioneira, 1994.

DRUMMOND, R.; MORROW, B. Lessons Learned from the History of Interoperable B2B Communication. Drummond Group Inc. Fort Worth, Texas, p. 8. 2007.

ENAP. Sistema de coleta on-line do Censo Escolar da Educação Básica - Educacenso. $1^{\circ}$ Concurso Inovação na Gestão Pública Federal, 2011. Disponivel em: <http://inovacao.enap.gov.br/index.php?option=com_docman\&task=doc_view\&gid=313 >. Acesso em: 04 mar. 2013.

ENOKI, C. Gestão de Processo de Negócios, uma contribuição para a avaliação de soluções de Business Process Management (BPM) sob a ótica da estratégia de operações. Universidade de São Paulo. São Paulo. 2006.

ESCOBAR, H. M. White Book of e-Government Interoperability for Latim America and The Caribeam. Comunidade Européia: ECLAD e @LIS, 2007. 
EUROPEAID CO-OPERATION OFFICE. eGoia. Portal do Governo do Estado de São Paulo, 2006. Disponivel em: <http://www.egoia.sp.gov.br/index.htm>. Acesso em: 2 nov. 2011.

FDTE. Desenvolvimento de Modelo e espicificação de plataforma de integração com os requisitos de interoperabilidade dos sistemas de controle público em uso pelo Estado e destes com os sistemas municipais. Fundação Prefeito Faria Lima - Cepam. São Paulo, p. 90. 2009.

FERRER, F.; SANTOS, P.; QUEIROGA, A. (. E-government: o governo eletrônico no Brasil. São Paulo: Editora Saraiva, 2004.

FOUNTAIN, J. E. Bureaucratic Reform and E-Government in the United States: An Institutional Perspective. NCDG Working Paper $\mathbf{N}^{\mathbf{0}}$ 07-006, Amherst, 18 September 2007. 30 .

FUGINI, M. G.; MAGGIOLINI, P.; PAGAMICI, B. Por que é difícil fazer o verdadeiro "Governo-eletrônico". Revista Produção, São Paulo, v. 15 n³, p. 300-309, Dez 2005.

GARDA, A. F. Troca de informação em serviços públicos eletrônicos no Estado de São Paulo. Centro Estadual de Educação Tecnológica Paula Souza. São Paulo, p. 86. 2011 .

GODOY, A. S. Introdução à Pesquisa Qualitativa e suas Possibilidades. RAE - revista de administração de empresas, São Paulo, v. v.35 nº 2, p. 57 - 63, mar-abr 1995.

GOODE, W. J.; HATT, P. K. Métodos em Pesquisa Social. $4^{\text {a }}$ edição. ed. São Paulo: Cia Editora Nacional, 1969.

GOVERNMENT On-Line. Statistics Canada, 2007. Disponivel em: <http://www.statcan.gc.ca/pub/56f0004m/2007015/4054984-eng.htm\#a2>. Acesso em: Abril 2012.

GOVERNO FEDERAL. Padrões de Interoperabilidade de Governo Eletrônico. Ministério do Planejamento, Orçamento e Gestão, 2012. Disponivel em: $<\mathrm{http} / / / \mathrm{www}$.governoeletronico.gov.br/acoes-e-projetos/e-ping-padroes-deinteroperabilidade>. Acesso em: 19 Abril 2012.

HAFEEZ, S. UN Global E-government Survey 2003. UNDESA - UN Department of Economic and Social Affairs. New York, p. 114. 2003. 
HERÉDIA, V. Novas Tecnologiasnos processos de trabalho: efeitos da reestruturação produtiva. Scripta Nova - Revista Electrónica de Geografia Y Ciencias Sociales, Barcelona, v. VI, núm 170 (9), n. acessado em 11/11/2011 na Internet em: http://www.ub.edu/geocrit/sn/sn-170-9.htm, agosto 2004. ISSN ISSN: 1138-9788.

HOPKIRK, A. Case Study: The e-Government Interoperability Framework (e-GIF), procurement and innovation policies in action. London: The National Computing Center, 2008.

ICI. Sala de Situação. Instituto Curitiba de Informática, 2011. Disponivel em: <http://www.ici.curitiba.org.br/conteudo.aspx?idf=37>. Acesso em: 12 novembro 2011.

INSTITUTO SEVA. Cidade Democrática. Cidade Democrática, 2010. Disponivel em: <http://www.cidadedemocratica.org.br>. Acesso em: 31 ago. 2012.

INTERSYSTEMS. Ensemble. Intersystems Brasil, 2012. Disponivel em: <http://www.intersystems.com.br/treinamento/ensemble>. Acesso em: 12 Setembro 2012. ISO. TC 46/SC 4 Technical Interoperability. ISO, 2010. Disponivel em: <http://www.iso.org/iso/standards_development/technical_committees/list_of_iso_techni cal_committees/iso_technical_committee.htm?commid=48798>. Acesso em: 05 set. 2012.

KANASHIRO, M. M. Sorria, você está sendo filmado: as câmeras de monitoramento para segurança em São Paulo. Campinas: [s.n.], 2006. 124 p. Dissertação de mestrado apresentada ao Departamento de Sociologia do Instituto de Filosofia e Ciências Humanas da Universidade Estadual de Campinas.

KAO, J. Java Development News. The Serverside.com, 2001. Disponivel em: <http://www.theserverside.com/news/1365386/Developers-Guide-to-Building-XMLbased-Web-Services-with-the-Java-2-Platform-Enterprise-Edition-J>. Acesso em: 07 set. 2012.

KETTL, D. F. Public Bureaucracies. The Oxford Handbook of Political Institutions, p. $366-384,2008$.

KNIGHT, P.; FERNANDES, C.; CUNHA, M. (. ). E-Desenvolvimento no Brasil e no Mundo: subsídios ao programa e-Brasil. 1 ${ }^{\text {a }}$ Edição. ed. São Paulo: Yedis Editora, 2007. KOHLS, V. K. O reflexo da sociedade em rede nas organizações: a tecnologia da informação, a flexibilização e a descentralização concentradora (de poder e riqueza). 
REAd, Pelotas, v. 5 no 4, n. 12, p. 26, Nov-Dez 1999. disponibilizado em: http://read.adm.ufrgs.br/edicoes/pdf.php?cod_artigo=335\&cod_edicao=28\&cod_lista_edi $\mathrm{cao}=28$.

LALLANA, D. E. C. E-Government Interoperability: a review of Government Interoperability Frameworks in selected countries. $1^{a}$ Edição. ed. Bangkok: United Nations Development Programme, 2007.

LEI 12.058. Planalto, 13 Outubro 2009. Disponivel em: <http://www.planalto.gov.br/ccivil_03/_Ato2007-2010/2009/Lei/L12058.htm>. Acesso em: 5 Junho 2011.

LEI 9.454. Planalto, 07 Abril 1997. Disponivel em: <http://www.planalto.gov.br/ccivil_03/Leis/L9454.htm>. Acesso em: 04 Junho 2011.

LESKOVEC, J.; HORVITZ, E. Planetary-Scale Views on a Large Instant-Messaging Network. International World Wide Web Conference Com- mittee (IW3C2). Beijing, China, p. 10. 2008.

LÉVY, P. O que é o Virtual? Tradução de Paulo Neves. $1^{\text {a }}$ Edição - 1996, $3^{\text {a }}$ Reimpressão. ed. São Paulo: Editora 34 Ltda., 1999. 160 p. ISBN ISBN 85-7326-036-X.

LUNA, R. B. Integração horizontal de de ações governamentais. EAESP-FGV. São Paulo. 2007. (Dissertação de Mestrado).

MARQUES, M. S. C. Blogs podem ser a imprensa livre de uma nova era. GP de Cibercultura, IX Encontro dos Grupos/Núcleos de Pesquisas em Comunicação. Curitiba: Intercom - Sociedade Brasileira de Estudos Interdisciplinares da Comunicação. 2009. p. 15. Encontro realizado em 4 a 7 de setembro de 2009.

MEDEIROS, P. H. R. Governo Eletrônico no Brasil: aspéctos institucionais e reflexos na governança. Brasília: Universidade de Brasília, 2004.

MERTON, R. K. A Note on Science and Democracy. 1. Journal of Legal and Political Sociology, p. 115-126, 1942.

MESQUITA, C. D. S. F.; BRETAS, N. L. (Org.) Panorama da interoperabilidade no Brasil. 1. ed. Brasília: MP/SLTI, 2010. 251 p. ISBN ISBN 978-85-89199-07-0. 
MIYAMARU, F.; FILGUEIRAS, L. X-Gov: crossmedia for government services. Proceedings of Workshop on Design \& Evaluation of e-Government Applications and Services. Uppsala, Suécia.: DEGAS. 2009. p. 8.

MOURA, M. Governo Eletrônico e Aspectos Fiscais: a experiência brasileira. Texto para Discussão no 1089, Rio de Janeiro, maio 2005.

MOURA, P. G. M. D. Sociedade e Contemporaneidade. $1^{a}$. ed. Curitiba: IESDE Brasil S.A., 2007. 112 p. ISBN ISBN: 978-85-7638-748-0.

MS. Sistema Único de Saúde: princípios e conquistas. Brasília: Ministério da Saúde do Brasil, 2000. 44 p.

MURRU, M. E. E-Government: from real to virtual democracy. Boston: Boston University, 2003.

NEGROPONTE, N. A vida digital. São Paulo: Companhia das Letras, 1995.

NETO, J. B. G. O Sistema Integrado de Informações Educacionais - Sied. Congresso de Informática Pública (Conip). São Paulo: Conip. 1999. p. 111-119.

OATES, W. E. An Essay on Fiscal Federalism. Journal of Economic Literature, Pittsburgh, PA - USA, Vol. XXXVII, September 1999. 1120-1149.

O'DELL, P. Silver Bullets: How Interoperable Data Will Revolutionize Information Sharing and Transparency. Bloomington, Indiana: Author House, 2010.

ONU/ASPA. Benchmarking E-government: a global perspective. New York: [s.n.], 2001.

PACHECO, R.; KERN, V. Arquitetura conceitual e resultados da integração de sistemas de informação e gestão da ciência e tecnologia. DataGramaZero - Revista de Ciência da Informação - Informação, Práticas e Políticas, Publicação eletrônica, v. 4, abril 2003. ISSN n. 2 - disponível em: http://www.dgz.org.br/abr03/F_I_aut.htm.

PARDO, T. A.; BURKE, G. B. Improving Government Interoperability: a capability framework for government managers. Albany: Center for Technology in Gvoernment University at Albany, 2008.

PEREIRA, E.; GENESTRETI, G.; TEIXEIRA, R. Cotidiano - Saúde, segurança e transporte preocupam paulistanos. Folha de São Paulo, 2012. Disponivel em: 
<http://www1.folha.uol.com.br/fsp/cotidiano/52058-saude-seguranca-e-transportepreocupam-paulistanos.shtml>. Acesso em: 03 nov. 2012.

PINTO, S.; FERNANDES, C. Institucionalização do governo eletrônico no Brasil. Congreso Internacional Del Clad Sobre La Reforma Del Estado Y de La Administración Pública. Santiago, Chile: Anales. 2005. p. 10.

PRATES, G. A.; GALLÃO, D. Panorama do EDI (Electronic Data Interchange) nas organizações brasileiras. QUALIT@S Revista Eletrônica, João Pessoa, PB, v. 6 nº 2, p. 14, 2007. ISSN ISSN 1677-4280.

QIAN, H. (. ). United Nations e-Government Survey 2010. New York: United Nations, 2010.

QIAN, H. (. ). United Nations e-Government Survey - 2012. New York: United Nations, 2012.

QUALMAN, E. Socialnomics: How Social Media Transforms the Way We Live and Do Business. 1 ${ }^{\text {a }}$. ed. Hoboken: John Wiley Trade, v. 1, 2009. ISBN 0470477237.

REPÚBLICA FEDERATIVA DO BRASIL. Governo Eletrônico. Governo Eletrônico, 2009. Disponivel em: <http://www.governoeletronico.gov.br>. Acesso em: 18 Agosto 2009.

REZENDE, F. Cooperação Intergovernamental. Cadernos Fórum Fiscal. Brasília, DF: Fórum Fiscal dos Estados Brasileiros. 2006. p. 96.

RIBEIRO, P. T. A descentralização da ação governamental no Brasil dos anos noventa: desafios do ambiente político-institucional. Ciência \& Saúde Coletiva, [on line], 14, 2009. 819-828.

RIEMPP, G.; MÜLLER, B.; AHLEMANN, F. Towards a Framework to structure and assess strategic IT/IS management. Mannheim: University of Mannheim, 2008.

SANCHEZ, A.; JANOWSKI, T.; ESTEVEZ, E. Interoperability for Eletronic Government. Macao: United Nations University - International Institute for Software Technology, 2008.

SANTOS, E. M. D. Desenvolvimento e implementação de padrões de interoperabilidade em governo eletrônico no Brasil. Universidade de São Paulo. São Paulo, p. 184. 2008. (CDD 658.4038). 
SANTOS, R. J. L. Governo Eletrônico: o que se deve e o que não se deve fazer. XVI Concurso de Ensayos y Monografías del CLAD sobre Reforma del Estado y Modernización de la Administración Pública "Gobierno Electrónico". Caracas: CLAD. 2002.

SANTOS, R. S. D. Interoperabilidade do Governo Brasileiro. IX Congresso Internacional del CLAD sobre la Reforma del Estado Y de la Administración Pública. Madri: [s.n.]. 2004.

SANTOS, R. S. D.; CORTE, L.; MOTTA, L. B. Padrões de Interoperabilidade de Governo Eletrônico (E-ping) qualificam a prestação de serviços ao cidadão. In: KNIGHT, P. T. Rumo ao e-Brasil. Rio de Janeiro: Gramond, 2006.

SELlTIZ, C. et al. Métodos de Pesquisa nas Relações Sociais. $2^{a}$ Edição. ed. São Paulo: Ed. Herder e Editora da Universidade de São Paulo, v. 1, 1972.

SERPRO. Interoperabilidade Segue Plano de Gestão. Revista Tema, Brasília, v. 172, n. 1, p. 6, março/ abril 2004. ISSN ano XXVIII.

SILVA, C. R. C. D. et al. Governo Eletrônico em Ambientes Colaborativos Virtuais. V Simpósio Brasileiro de Sistemas de Informação - Workshop de Teses e Dissertações, Brasília, 22 Maio 2009. 12.

SILVA, E. L. D.; MENEZES, E. M. Metodologia da Pesquisa e Elaboração de Dissertação. 3a edição revisada e atualizada. ed. Florianópolis: UFSC, v. 1, 2001.

SLTI, S. D. L. E. T. D. I. D. M. D. P. E. G. Pesquisa E-ping - Respostas. Pesquisa Eping, 2007. Disponivel em: <www.governoeletronico.gov.br/anexos/pesquisa-e-pingrespostas>. Acesso em: 02 nov. 2011.

SOUZA, C. A. D. Sistemas Integrados de Gestão Empresarial: estudos de caso de implementação de sistemas ERP. FEA/USP. São Paulo, p. 253 p. 2000.

SOUZA, M. I. F.; VENDRUSCULO, L. G.; MELO, G. C. Metadados para a descrição de recursos de informação eletrônica: utilização do padrão Dublin Core. Ciência da Informação, Brasília, v. v. 29, n. n. 1, p. 93-102, jan/abr 2000.

SOUZA, N. G. D. Integração de sistemas de informação na Segurança Pública do Distrito Federal: um modelo de consenso e suas possibilidades. Brasília: Universidade Católica de Brasília, 2003. 208 p. Dissertação. 
SOUZA, N. L. P. N. D. Dinâmica das Relações Intergovernamentais no Processo de Descentralização da Saúde : O Caso do Município do Rio de Janeir. Escola Nacional de Saúde Pública - Fundação Oswaldo Cruz. Rio de Janeiro. 2010.

STAKE, R. E. Qualitative Case Studies. In: DENZIN, N. K.; LINCOLN, Y. S. (. ). Handbook of qualitative research. 3rd Edition. ed. Thousand Oaks, CA: Sage, 2005. p. $435-454$

STRAUSS, A.; CORBIN, J. Basics of Qualitative Research. London: Sage Publications, 1990.

TAKAHASHI, F. Cotidiano. Folha de São Paulo, 2010. Disponivel em: <http://www1.folha.uol.com.br/fsp/cotidian/ff3112201008.htm>. Acesso em: 12 novembro 2011.

TAKAHASHI, T. (. ). Sociedade da Informação no Brasil: livro verde. Ministério da Ciência e Tecnologia. Brasília. 2000.

TARAGINO ET AL, R. SINGRA-SIASG: Integração do sistema de abastecimento da Marinha com o Gvoerno Eletrônico. Rio de Janeiro: Imprensa Oficial, 2005.

TCE-SP. Proc.TC-026453/026/10. Diário Oficial Poder Legislativo, São Paulo, 23 fevereiro 2011. $121(35)-39$.

TOFFLER, A. A terceira onda. Tradução de João Távora. $20^{a}$. ed. Rio de Janeiro: Record, 1995. 491 p. Copyright 1980 by Alvin Toffler.

TULL, D. S.; HAWKINS, D. I. Marketing Research, Meaning, Measurement and Method. London: Macmillan Publishing Co. Inc., 1976.

VASSILAKIS, C.; LEPOURAS, G. An ontology for e-Government Public Services. In: INC., I. G. Encyclopidea of E-Commerce, E-Government and Mobile Commerce. Athenas: Idea Group Inc., 2006. p. 865-870.

W3C BRASIL. A demanda por interoperabilidade na Web é maior do que antes. http://www.w3c.br/Noticias/W3cConfirmaLastCallDoHtml5ParaMaioDe2011EPadr aoCompletoPara2014, acessado em 11 de novembro de 2011, 14 fevereiro 2011. 1.

WAUTERS, P. User expectations of a life events approach for designing egovernment services. Deloitte and European Comission. London. 2010. 
WEBER, M. Burocracia. In: WEBER, M. Ensaios de Sociologia. $5^{\text {a }}$ edição. ed. Rio de Janeiro: LPC, 2002. p. 138-167.

YILDIZ, M. E-Government research: reviewing the literatura, limitations and ways forward. Hacettepe: Hacettepe University, 2007.

YIN, R. K. The Case Study Crisis - Some Answers. Administrative Science Quartely, Ithaca, Vol. 26, March 1981. pp. 58 - 65.

YIN, R. K. Case Study Research - Design and Methods. Third. ed. Thousand Oaks: Sage Publications Inc., v. 5, 2003. 